University of Louisville

ThinkIR: The University of Louisville's Institutional Repository

\title{
Costume design for the UofL Department of Theatre Arts' production of Tim Robbins' Dead man walking.
}

\author{
Rachel Jennifer Siow \\ University of Louisville
}

Follow this and additional works at: https://ir.library.louisville.edu/honors

Part of the Theatre and Performance Studies Commons

\section{Recommended Citation}

Siow, Rachel Jennifer, "Costume design for the UofL Department of Theatre Arts' production of Tim Robbins' Dead man walking." (2014). College of Arts \& Sciences Senior Honors Theses. Paper 78. http://doi.org/10.18297/honors/78

This Senior Honors Thesis is brought to you for free and open access by the College of Arts \& Sciences at ThinkIR: The University of Louisville's Institutional Repository. It has been accepted for inclusion in College of Arts \& Sciences Senior Honors Theses by an authorized administrator of ThinkIR: The University of Louisville's Institutional Repository. This title appears here courtesy of the author, who has retained all other copyrights. For more information, please contact thinkir@louisville.edu. 
Costume Design for the

UofL Department of Theatre Arts' Production of

Tim Robbins' Dead Man Walking

By

Rachel Jennifer Siow

Submitted in partial fulfillment of the requirements for Graduation summa cum laude

University of Louisville

May, 2014 


\section{TABLE OF CONTENTS}

I. INTRODUCTION

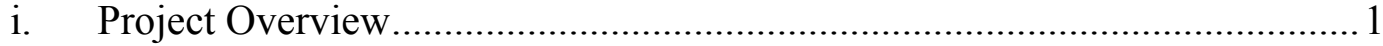

ii. About the UofL Costume Shop............................................................ 1

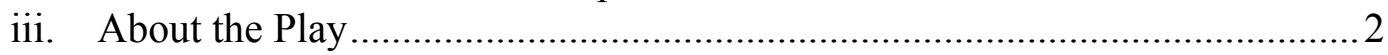

II. THE PROCESS

i. Design Concept .....................................................................................

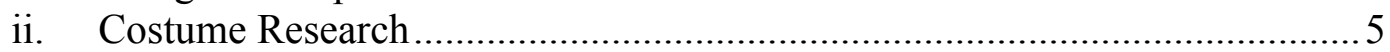

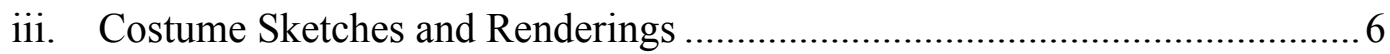

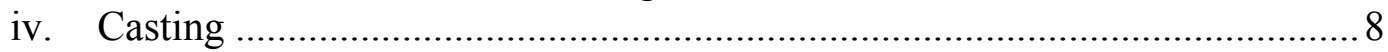

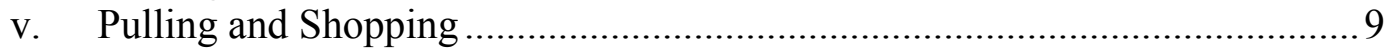

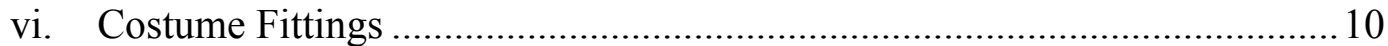

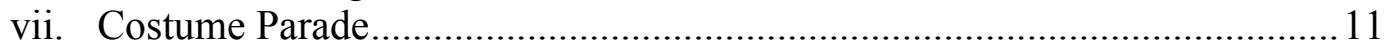

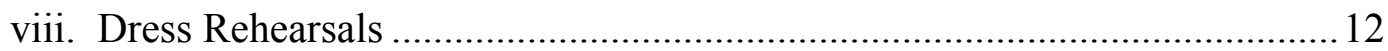

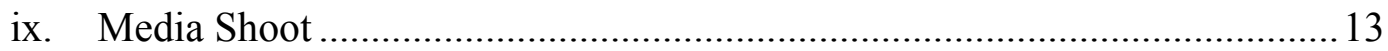

III. DISCUSSION

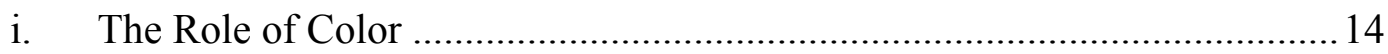

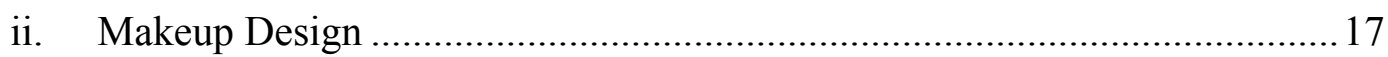

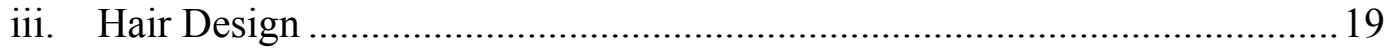

IV. CONCLUSION

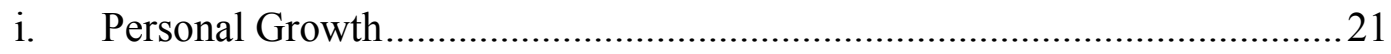

V. APPENDIX

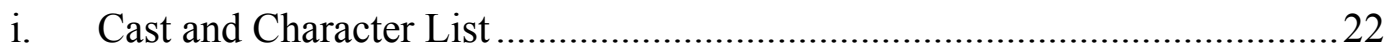

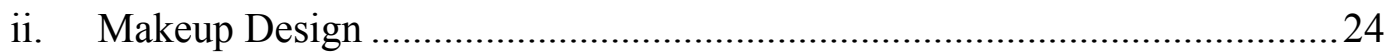

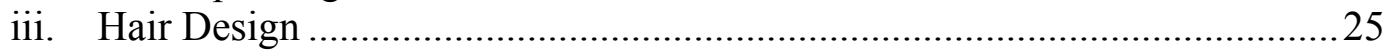

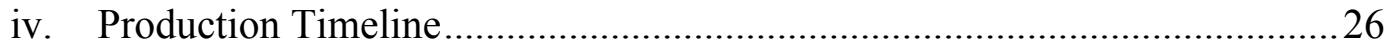

v. Account of Preliminary Meetings with Director..........................................28

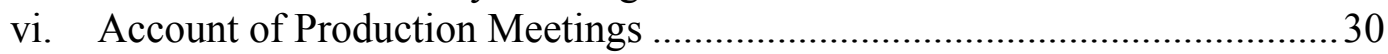

vii. Notes from Rehearsals and Costume Parade ……......................................... 32

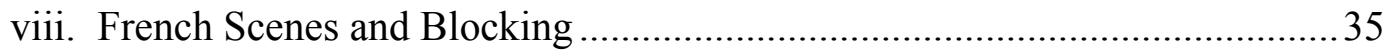

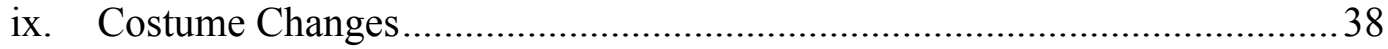

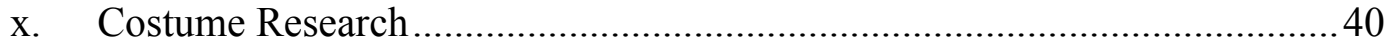

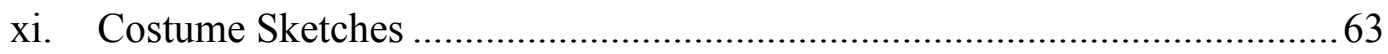

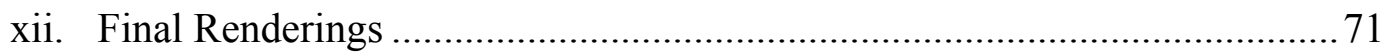

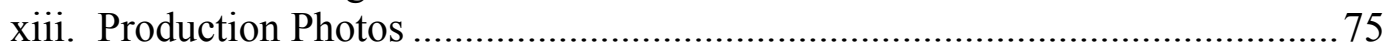

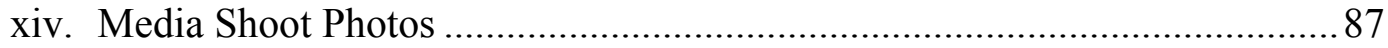

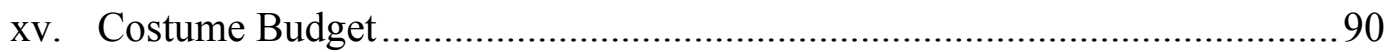

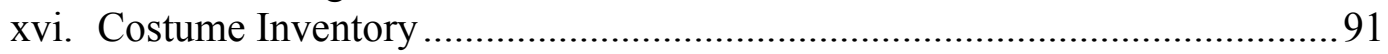

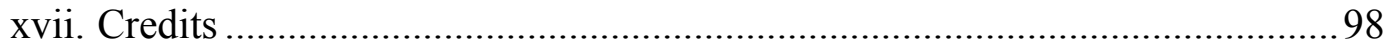

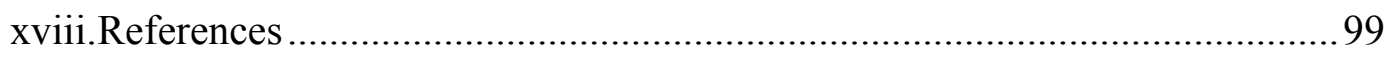




\section{INTRODUCTION}

\section{Project Overview}

The University of Louisville Department of Theatre Arts produces five to six mainstage shows per season. A mainstage show is a full-scale production that is performed in one of two UofL theatre spaces. As an academic theatre, many opportunities are available for students to participate in the production process, including stage managing, acting, technical work, and designing. My thesis project was the costume design for the department's mainstage production of Tim Robbins' Dead Man Walking.

As a student designer, my work was supervised by Zhanna Goldentul, the department's resident costume designer and costume studies professor; she was present for every step of the process, from early meetings with the director to costume fittings to final dress rehearsal. My duties as the costume designer entailed extensive creative and practical work with the costumes, from researching, designing, and sketching the costumes, to holding costume fittings with actors and completing alterations. I worked closely with the director, Russell Vandenbroucke, and the entire design and production team to realize a successful production. Costume work on this production began in August of 2013, and lasted through closing night in February of 2014; for the complete calendar, please refer to the Production Timeline (Appendix p. 26). The sewing, design, and collaborative skills learned during the course of this project are applicable to a wide range of future theatre work, both on the graduate and professional levels.

\section{About The UofL Costume Shop}

The costume shop is responsible for providing all costume and accessory pieces for the department's mainstage productions. The shop has a distinct structure and working process that helps 
accomplish this goal. Costume designs are provided for a show, usually by our resident costume designer, Zhanna Goldentul. The costume shop manager, Melissa Shepherd, then organizes work for the crew so that these designs can be brought to life.

The costume shop crew consists of four to six undergraduate students working in assistantship positions; I am one of these students. The assistantship positions provide students with hands-on training in costume work, costume shop management, and costume design. As part of the design training, each student on crew is assigned to assist the designer on one show during the season. This gives us a chance to become more familiar with the process of costume design.

Of the students on the crew, one is selected to be the Costume Buyer and another is selected to be the Wardrobe Master. The Costume Buyer shops for costume pieces, fabric, and supplies per the designer's request. The Wardrobe Master is responsible for attending rehearsals with the designer to gather costume information. The Wardrobe Master is also responsible for training the running crew; these are other undergraduate students who will be backstage during the run of the show, working with the actors and helping with quick costume changes.

\section{About the Play}

Dead Man Walking tells the story of Sister Helen Prejean's work with an inmate on Louisiana's Death Row in the 1980s. The script and its characters are based on the true events of Sister Prejean's life; the inmate she counsels in the play, Matthew Poncelet, is an amalgamation of two Death Row inmates Sister Prejean counseled in the early 1980s: Robert Lee Willie and Patrick Sonnier. Sister Prejean chronicles her work with these and other death row inmates in two books: Dead Man Walking (1993) and The Death of Innocents (2005). It was Sister Prejean's first book, Dead Man Walking, that inspired playwright and director, Tim Robbins, to adapt the story to film in 1995 and then again to the stage in 2002. 
In the play, Sister Helen receives a letter from Matthew Poncelet, an inmate on Louisiana's Death Row, and begins a written correspondence with him. Through her letters and subsequent visits with Matt in prison, Sister Helen learns about Matt's background, his murder of a young teenage couple, and the cultural circumstances that led him to prison. She agrees first to help him file the paperwork for a pardon board hearing; when the pardon board denies him clemency, Sister Helen agrees to be Matt's spiritual advisor until his execution. Through her association with Matt, Sister Helen reaches out to the many people his actions touched, from the parents of the murdered teenage couple to Matt's own family. With Sister Helen's friendship and guidance, Matt is able to accept his responsibility in the murders, offer the murder victims' parents solace in his death, and die with dignity.

Throughout the play, Sister Helen encounters many different perspectives surrounding the concept of a death penalty. All of the characters she meets have a different opinion of Death Row inmates or of those who work with them. The differing viewpoints provide the audience with many lenses through which to examine a difficult issue. Though the script does not necessarily promote one viewpoint over another, it does seem to be written to inspire a discussion about the issues surrounding the death penalty. 


\section{THE PROCESS}

\section{DESIGN CONCEPT}

My duties as the costume designer began with the development of an overall design concept for the costumes. Doing so required that I meet with the director, Russell Vandenbroucke, to discuss our thoughts about the play. As per the preferences of our department, all meetings between a faculty member and student should take place in the presence of the student's faculty supervisor; this ensures that any concept discussed for a show is kept within the abilities of the department's resources. Therefore, as my supervisor, Zhanna Goldentul attended all of my meetings with the director. In the context of these meetings, Zhanna also became a collaborative third party to the ideas discussed.

The first major decision regarding a design concept was selecting a time period for this production. Since the play is so rooted in historical events and real lives, the director thought it best to retain the period in which the play has been set: Louisiana in the early 1980s. This decision helped provide a more accurate portrayal of the events that led Sister Prejean to her current work in social justice. Retaining the time period might also help the audience connect moments on stage with experiences they actually lived through.

A design concept for the costumes began to emerge as the director and I discussed our impressions of the play. It was important to the director that this production humanizes the oftoverlooked issue of the death penalty and he requested that the costumes somehow play into the creation of this reality. We both felt that those characters closest to Matthew - whether they were his family and friends, or the families he destroyed - had the most poignant stories to tell and that these stories would be most empathetic to an audience. I suggested that we use the colors of the costumes to help these characters stand out for the audience and other, less empathetic characters melt away. 
Thus, I proposed that we use two color palettes for the show: warm and bright colors and cool, muted colors. Those characters closest to Matt (his family and lawyer, the families of the murder victims, and the three Sisters) were dressed in the brighter, warmer colors and textured or printed fabrics that were characteristic of the 1980s. The vivid or otherwise strong colors of these characters brought their stories to life and created more of a reality around their experiences. Those characters more removed from Matt (the Governor and District Attorney, the reporters, prison officials, and prisoners) were dressed in the cool, muted colors with grey undertones that blended into the all grey set and scenery. The effect was that any character dressed vividly stood apart from not only the scenery, but also those characters dressed in greys.

\section{COSTUME RESEARCH}

The purpose of costume research is to provide an accurate basis for the costume designs. Extensive information was gathered on the historical period, the climate of the area, the lifestyle of the people, and the fashions prevalent at the time (Batchelor and Stoddart 67-77). Some interesting challenges arose during my research. First, the location (Louisiana) and the characters (generally less fashionable) made it harder to find appropriate reference images. Most characters in the play would not have dressed in the high fashions of their times as their priorities were other than their clothing. As such, their clothes would be practical, "everyday" wear with little glamour. Therefore, fashion magazines and the work of prominent fashion designers were not useful as references.

The time period of the play (the early 1980s) was also a challenge to work with. Most traditional costume history texts tend to focus on clothing styles before the mid-Twentieth Century; these fashion periods tend to have a more cohesive style that creates distinct and easy-to-define lines between them. Such distinctions become blurred the closer one gets to present-day fashions, especially with the recent trend to bring back elements from other fashion eras. For a close-to- 
contemporary period like the 1980 s, it was easier to find accurate information on the Internet than in the printed books I usually refer to.

Clothing trends are often reflected in popular culture of the time, so I turned to media from the 1980s to examine the clothing worn there: The Bill Cosby Show, Cheers, and Miami Vice are among the television shows I researched. Movies served as inspiration as well: Wall Street, The Breakfast Club, and The Outsiders. In addition to television and movie characters, many real-life figures from the 1980s became references for my designs: Queen Elizabeth of England, Governor Edwards of Louisiana, Bill Clinton, Warden Burl Cain of the Louisiana State Penitentiary, Robert Lee Willie, Patrick Sonnier, and Sister Helen Prejean. To complete my research, I also gathered images of the illustration plates from 1970s and 1980s sew-at-home clothing patterns. And with the current resurgence of "vintage" fashions, I was able to find many images of actual 1980s garments and accessories for sale on online websites like Etsy and Ebay.

My research resulted in a collection of images that suggested style and color for each character's garments and accessories. This collection became the backbone of my costume design and I used it to present my preliminary design ideas to the director. I modified images in the collection as necessary, then used them as references for my costume sketches and as a guide while pulling and shopping for actual costume pieces.

\section{COSTUME SKETCHES \& RENDERINGS}

Generally, once a collection of research images has been compiled, the next step is to make pencil sketches of each character in costume (Appendix p. 63). Ideally, two to three complete looks for each character would be sketched and presented to the director as possible options. Once the designer and director decide on a particular look for the character, full-color costume renderings are 
made for each character; these illustrations provide the costume shop with the details necessary to construct each garment.

This sketching and rendering process is particularly important when designing a "built" show. Built shows are often fantasy shows or "period" shows (set in a time period with distinct styles and strict fashion rules that must be replicated accurately). The garments required for such shows are not easily found in a modern clothing store and so a costume shop must construct (build) most or all of the costume pieces. On the other hand, a show set in a period closer to present-day is generally a "bought" show. These time periods in fashion are not as clearly defined, so there is more leeway when selecting costume pieces. Many costume pieces for a bought show can be purchased in a store or found in an existing costume collection like the one at UofL.

For a close-to-contemporary show like Dead Man Walking, it was not necessary to make fullcolor renderings for the characters. In fact, this step would have been impractical for this particular show due to the large cast and multitude of characters. Since color was the basis of my thesis, I knew I would need to be selective about this element when finding costume pieces. I needed to retain the ability to adapt my designs to the costume pieces my resources provided me with; this meant that I did not render final designs until the show opened. Instead, I sketched some options for about 10 of the larger roles and used mostly my research images to make final decisions about costume pieces.

After the run of the production, I made final renderings of the costume design for four characters I thought would help illustrate my design concept (Appendix p. 71). Although I did not follow the traditional design process, this step allowed me to have final renderings to include in my portfolio of designs, a collection of my work kept to showcase my skills when applying for future jobs and graduate school. 


\section{CAsting}

Casting the actors for this show was a very involved project. The cast size limit had been set at 18 actors, but there were more than 50 roles to be portrayed. This meant that extensive doubling and tripling of parts would be required (one actor playing multiple roles). To work this out practically meant not only considering the gender and age of each actor compared to the character pool, but also considering every entrance and exit of a character. The actors must have sufficient time in between a character change to make the costume changes that help distinguish those characters. And in a show with so much doubling of roles, costumes did become a very important part of helping clarify those distinctions. Therefore, any decisions made about casting could greatly impact the decisions I could make about how to costume these actors.

The director was generous enough to invite Zhanna and me to be a part of the casting process. We met two times in early November 2013 to discuss possibilities for doubling. A large part of the discussion was centered around the practicality of the actors changing between characters. However, we also discussed ways that gender or race of some characters might be adapted to alleviate some of the doubling pressures. For example, the Percy family was cast as African American and this meant that the teenage couple became interracial. Although this decision inserted racial issues into the play, we decided that those issues (like the murder of an interracial couple by a man who is a white supremacist) fit into the world of the play enough to be justified.

In the case of Jim Poncelet, a younger brother of Matt, this part was changed to "Jamie Poncelet", a tomboy younger sister. Such a choice opened up an opportunity for a female actor whose training made her more versatile to play other roles in the show, as opposed to casting a young male actor who could only play the one role. This choice provided the cast with a female actor to fill the role of Sister Helen's Mother as well as fill one of the female support group roles. 
My inclusion in the casting process made it easier to finalize my designs because it provided me with such intimate insight into the doubling and tripling scheme that was devised. Since I had knowledge of which actors I would be working with and what kind of character changes they would be making, I was able to begin planning how to make speedy transitions between the costumes needed to portray each character.

\section{Pulling \& ShOPPING}

Once the cast list was posted, all actors were called in for measurements. With measurements of all actors in hand, the costume assembly process began with a trip to the University's "costume stock." This collection contains clothing from a wide range of time periods as well as a variety of accessories, including hats, shoes, belts, handbags, scarves, and jewelry. With the help of the entire costume shop crew, the initial pull of garments and accessories from UofL's costume stock took place during the first week of December 2013.

A pull of such magnitude required a good deal of organization. To streamline the pull, I made a list of all garments for each character plus a preferred color palette for the costume pieces. As crew members found appropriate options in the actor's size, each costume piece was shown to me for consideration and approval. Generally, we pull one to three options for each piece an actor requires; since many garments look different on a hanger than they do once dressed on an actor's body, this ensures that the designer will have some choices. As options were selected, the pieces were bundled together by actor and transported back to the costume shop.

For any show at UofL, we try to use as many pieces from stock as possible; however, it is very rare that a show can be assembled from stock alone. Any pieces that could not be found in stock during the initial pull were added to a shopping list and shopped for during the rest of the week. We visited various stores in search of costume pieces, including Walmart, Target, Kohl's, Bluegrass 
Uniforms, and Goodwill; online vendors like Amazon, Ebay, and Etsy proved to be good sources of costume pieces as well (see Appendix, p. 90, for complete list of vendors). This process of pulling from stock and shopping was repeated as the costume designs were modified and as costume pieces were "struck" (removed from the show) after a costume fitting deemed them to be unfit.

\section{COSTUMe FitTings}

By the end of the first week of December 2013, one or two preliminary looks were assembled for each character. The following week was used to hold the first round of costume fittings with each actor. During a costume fitting, the actor tries on all of the costume pieces. The fit of each option is examined, as well as the style and color of the garment in regards to the actor's body shape and complexion. Many pieces that seem to be great options while on a hanger prove to be less than flattering once on an actor's body. In the case of Sister Helen, we tried at least 10 different skirts, seven jackets, four blouses, and three suits before we found a combination that flattered both the actor's complexion and body shape. Though this is a more extreme example, it is not uncommon; certain body shapes can be harder to work with than others.

Once good options were selected, the fit and style of a garment could often be improved with alterations. If any alterations were needed, they were pinned in place and notes were taken on how the piece should be modified. Additional notes were made if a costume piece needed to be dyed or if additional accessories and/or costume pieces needed to be pulled or shopped for. Alteration notes became the to-do list for the costume shop crew and pulling and shopping notes became my to-do list as the designer.

We were able to see all but one of the actors for an initial costume fitting before the University closed for winter break. During the break, I was able to shop (both in-store and online) for all new items needed. When school reconvened for the spring semester in January, we held a second 
round of fittings with all actors who had new costume pieces. Notes were made on any alterations required and these alterations were completed in time for the costume parade. Any pulling and/or shopping notes that were made during this round of fittings were completed in time for the costume parade as well; the parade itself would serve as a fitting for these new pieces.

\section{Costume Parade}

During a costume parade, actors are seen on stage in full costume; they are often called on stage in groups, either based on character relationships or based on scenes from the script. A costume parade allows the director and the designer an opportunity to see the costumed actors together and discuss the designs.

Our costume parade took place on January 15, 2014, two weeks before the show opened. I prepared a list of which groups of actors to see and in what order to minimize the changes between characters that each actor would have to make. The director, my supervisor, and I discussed the costume designs of each character as we saw them on stage. This was a chance for the director to voice any concerns about what he saw and for me to explain some of the decisions I made during the fittings. The costume shop crew was present to mark and pin garments for alterations and notes were taken for all issues discussed (Appendix p. 32).

During the parade, it became evident that some costumes were simply not going to work. For example, Sister Helen's Mother needed a completely new look that would help age the actor. The dress I had originally selected for this character seemed much too "young" once seen next to Sister Helen's look. In addition, we paid particular attention to the distinctions between an actor's multiple characters. Hats, scarves, and glasses were added to many minor characters during the parade to help create a unique visual for each character. 
Alterations were completed after the parade and another round of pulling and shopping yielded another round of fittings for new pieces. The finished and complete costumes were inventoried (Appendix p. 91) and loaded into the dressing rooms by Thursday, January 23, three days before First Dress Rehearsal.

\section{DRESS REHEARSALS}

The last three rehearsals before a show opens are called the dress rehearsals. These rehearsals are the first time that the actors rehearse the show in full costume (hair, makeup, and clothing). During these dress rehearsals, the actors were taught how to wear each costume and when to change costumes. Likewise, the running crew is trained to maintain the costumes backstage and help the actors with quick costume changes during the show. The running crew is also responsible for laundering the costumes, and this skill is usually taught after final dress rehearsal.

During the dress rehearsals, I had a chance to refine and finalize my designs with the director. These rehearsals were my last chance to ensure my designs were accurate and justified in the context of the entire production. I noted any costume-related issue that arose during rehearsal and sat down with the entire cast to explain these notes to them at the end of each rehearsal (Appendix p. 33). I also spoke with the director after each rehearsal to address any of his costume-related concerns from the evening.

At the conclusion of the final dress rehearsal, I had a photo call with the actors to capture production photos for my portfolio (Appendix p. 75). When the show opened the following night, my duties as costume designer had been fulfilled. 


\section{Media SHOOT}

An unplanned media shoot was required for this production. The script called for the projection of statistics and photos onto the set (Robbins 1, 5, 15, 17, 20, 21, 32, 39, 49). In addition to these elements, the director also wanted to project recordings of the TV Reporter's interview of Matt Poncelet (Robbins 48) and the meeting with the Governor (Robbins 69). During the course of the production meetings, it became apparent that acquiring these media would require a special event involving the collaboration of the director, stage manager, media and costume designers, and the actors. Thus, a separate media shoot was scheduled for Friday, January 17, to photograph and film the necessary segments.

For the filmed scenes, the actors were provided with the costumes they would wear in the show. Additional costumes had to be assembled for the 1970s prom photo of the murdered teenage couple, Hope Percy and Walter Delacroix (Appendix p. 88). Special effects makeup was also required for the "morgue" photos of Hope and Walter (Appendix p. 89). These costume and makeup designs were used for the photography session only and did not appear during the run of the show. They were design elements not accounted or budgeted for in the original production plans. Though the media shoot was successful, it was a side project that became much more time intensive than anyone had intended. 


\section{DISCUSSION}

\section{The Role of Color}

My design concept for this show was centered around color. I wanted to use warmer, more vibrant colors to emphasize those characters whose stories were most poignant; I wanted to dress the other characters in cooler, greyish colors to help them blend into the background. In many cases, I was able to maintain this concept over the course of the production and this was reflected in the final renderings (Appendix p. 71) and production photos (Appendix p. 75).

Sister Helen (Appendix p. 71) was dressed in a warm burgundy skirt suit and cream blouse for the first act of the play; in the second act she replaced the suit jacket with a cream tweed blazer. The predominant burgundy color of her costume suggests warmth; though the color is somewhat muted, it fits with the conservative and understated nature of a nun. The red undertones of the burgundy and the bold pattern of the tweed jacket also suggest strength, a quality that I definitely wanted to bring out in the costume design for this character.

Matthew Poncelet (Appendix p. 72) was dressed in the denim shirt and jeans uniform described in the script (Robbins 8) This description was consistent with the uniforms worn by prisoners in the Louisiana State Penitentiary today (Louisiana State Penitentiary). The light blue color of his uniform stood out against the grey set. However, its cool undertones suggested little warmth in this character. Under the cool stage lights, the uniform appeared even more faded and bleak, thus lending a rather stark appearance to this character.

Hope Percy (Appendix p. 74) wore a light pink shirt with a multi-colored printed skirt and hot pink belt. Her navy blue sneakers were tied with hot pink laces and she sported a blue class pin as specified in the script (Robbins 44). The bright colors and bold patterns of this costume brought the 
character to life on stage. Hope's vibrant appearance contrasted sharply with the knowledge that this character had been murdered, emphasizing the tragedy of her death.

Walter Delacroix (Appendix, p. 73) was dressed in a white baseball tee with blue raglan sleeves, blue jeans, and Chucks sneakers. This costume was typical of a young 1980s male. The bright blue of Walter's shirt complemented the bright colors of Hope's costume, helping identify these two characters as a couple. The blue color also helped Walter stand out from other characters dressed in subtler colors. As with Hope, the vibrancy of Walter's costume accentuated the tragedy of his death.

Though many characters were strong examples of my design concept, the concept was not evident in all of my costumes for a number of reasons, including: my internalized budget restrictions, the character's qualities, and the lighting design.

A major factor influencing my design decisions was my budget. Though the show had been assigned a larger-than-average budget, we were still responsible for costuming 18 actors and over 50 characters. Additionally, the script called for four uniformed prison guards and three uniformed prisoners. Uniforms have a tendency to be a major expense for a show. There is little leeway when dealing with uniforms as they have strict guidelines about color, fit, and decoration. Uniforms must be recognizable with accurate insignia and it can be difficult to find the proper garments, badges, patches, and decorations. I knew that I may have to buy and decorate a full set of matching uniforms for the guards and prisoners, and I was familiar with the expense this could entail.

Knowing the above details in advance made me internalize a sense of caution and frugality when I assembled the costumes. As much as I could, I tried to not compromise on my color palette, but there were instances where saving money or time meant doing so. Learning how to budget a show and minimize unnecessary compromises is an important skill as a designer. Even through all of the 
challenges, we were able to pull more pieces from our stock than we anticipated and so were able to stay well below budget.

Although I wanted to exaggerate the differences between my more empathetic and less empathetic characters, the backgrounds of these characters limited my ability to do so. Many of the characters would not have paid particular attention to their clothing; their particular profession or life situation took priority over their clothing choices. The Percys, Delacroixs, the Poncelets and the support group victims were all mourning the loss of a family member; their stories are pivotal to the plot of the play and some of the most heart wrenching. Though I could have dressed these characters completely in bright, bold colors (as was fashionable in the 1980s) it would not have made sense to do so. These characters would not have cared about the most current fashions, nor would they have chosen the loudest colors in their various states of mourning. Though my concept dictated that these characters be dressed more vividly than the rest, sometimes a small pop of strong color on them was just enough to help them stand out.

The lighting design affected my costumes in such a way that my design concept may not have been as effective as I had planned. The lighting was often harsh, cool, and bright because the director had requested a sterility and absence of warmth in the lighting design to reflect the harsh reality of the play. This type of light changed the colors of the costumes I put on stage. Standing in this cool lighting, Sister Helen's warm burgundy suit appeared to be a brownish grey, a color I would have used for a less prominent character. In such light, the warmth and attention that I intended for Sister Helen's clothing to bring to her presence was lost. This became a problem for more than one character during the show. However, I did not realize how much of an effect the lighting would have on some of the costumes until the dress rehearsals. I may have been able to avoid such a problem had I met with the lighting designer to discuss the importance of color in both our designs; perhaps we could have collaborated to avoid such an effect. 
In fulfilling my design concept, my goal became to provide the audience with focal points in an overwhelmingly large show. I wanted to help my audience overcome the sheer number of characters and give them a chance to really hear what the characters had to say. I believe that the subtleties of my design concept touched all the characters in a way that supported the director in his vision to emphasize the humanity in this play.

\section{MAKeup Design}

Makeup design is concerned with any cosmetic aspect of the characters; this includes regular stage makeup, specialty makeup, and facial hair. Generally, a show will require the actors to wear "stage makeup," a basic makeup that ensures visibility of the actor's facial features (eyes, eyebrows, lips) under strong stage lights. Stage makeup includes elements of street makeup (the basic makeup that one might wear on a day-to-day basis) with the addition of character highlight and character shadow. These two makeup colors are used to create more contrast between the contours of an actor's face and help facial expressions be more distinguishable from the stage. By enhancing the facial features of an actor, their character's appearance becomes more distinct and more developed. Common makeup materials include: foundation, character highlight, character shadow, concealer, eyeliner, eyeshadow, mascara, brow pencil, lip color, and setting/face powder.

The makeup design for this production was kept to a minimum to reflect the solemnness of the situation and the reality of the characters. In a world the director described as having "no glitz and no glamour," it would not make sense for the characters to be heavily made up. Furthermore, since most actors played multiple characters, there was no opportunity to develop character makeup for any one role. Makeup takes times to apply and to remove; it is hard to change this element quickly and accurately during a performance. Establishing a certain makeup look for one character would limit the possibilities for the other roles that actor played; establishing a certain look could also make it 
harder to create clear distinctions between characters. Therefore, character makeup was not used in this show. The men were not required to wear makeup except for face powder to absorb perspiration and help prevent shine; the women were asked to wear a conservative, understated version of their normal street makeup.

Facial hair became a concern because of the doubling; many of the male actors were asked to alter their facial hair to better suit the period or the profession of their character. For example, correctional officers generally have strict hygiene requirements. Facial hair for officers is limited to a mustache at most; beards and goatees are not permitted for officers because they obstruct the face piece of a self-contained breathing apparatus (Allen 29). The actors playing prison guards were asked to shave their beards; this decision was one that affected the looks of their other characters.

However, with actors who played only one role, more could be done with their makeup look. White makeup was added to the beard and sideburns of Father Farley to give this character more age. White was also added to the sideburns of Earl Delacroix to add age to this character.

Special effects makeup was required during the media shoot for this show. Realistic "corpse" makeup was used on the actors who played Hope and Walter; this provided the media designer with morgue-like photos to use on the projector screens during the show. However, applying this makeup was a special one-time event; it was never required or applied during actual performances.

Tattoos were required on arms and left leg of the actor who played Matthew Poncelet. His arm tattoos are specified in the script as "a swastika and a skull, women's names and on one arm a naked woman" (Robbins 84). On his left leg, Matthew also had “a tattooed number” (Robbins 83). After meeting with the director, we decided that less was more in the case of tattoos on stage. We kept the tattoos designs bold and simple, using a swastika, skull, black widow spider, and two women's names (Appendix p. 84). 
The tattoos were drawn on the actor with Sharpie brand permanent marker then set in place by dusting with baby powder and spraying with a thin coat of hairspray. According to the research I did, such "tattoos" last for about one month ("How to make a Temporary Tattoo") so I thought this application method would be most promising. However, I was not completely satisfied with our

results. The tattoos faded quickly, which may have been a result of clothing rubbing against them. The actor was instructed not to wash the "tattooed" areas directly; he was also given a protective cast cover to use during his showers in attempt to protect the tattoos. Nevertheless, the tattoos still required reapplication almost every day during the run of the show. The experience of a professional may have helped us find a longer-lasting solution for these temporary tattoos, though one was not consulted for this project due to time constraints.

\section{HAIR DeSign}

Hair can be a pivotal part of the character; its design gives the audience clues about the character's age, heritage, style preferences, and profession. For example, the nuns all wore their hair in a conservative but distinctive low bun that reflected their modesty and visually connected them with each other (Appendix p. 76). Matthew Poncelet's somewhat arrogant personality was expressed in his hair's styled wave (Appendix p. 79, 82). Sister Helen's Mother had short, stylish grey curls that gave her age and refinement (Appendix p. 81). Even the male prison guards had short, neat hair and well-groomed facial hair that spoke of the practicality of their jobs.

In a show this large, changes in the women's hairstyles were used to help create distinctions between the characters an individual actor portrayed (Appendix p. 25). I used accessories like scarves, hair scrunchies, and headbands to help create different hairstyles. For example, the same actress played Hope Percy, Emily Percy, a Support Group victim, and a prison guard. To help with these character distinctions, she wore her hair down and loose as Hope, tied a scarf in her hair as 
Emily, used a hair scrunchie in a low ponytail as the Support Group victim, and pulled it back into a low bun as the prison guard. These hairstyles helped create different silhouettes that distinguished one character from another but were still simple enough to accommodate during quick costume and character changes. 


\section{CONCLUSION}

This project provided me with a safe learning environment in which I could observe, learn, and practice the skills necessary to be a successful costume designer. With the supervision of a professional in the field, I had both a good role model to look towards and a good reference to turn to. Designing costumes for a mainstage show is a huge responsibility to take on as a student. The support system that an academic theatre environment like ours provided helped build the confidence I needed to succeed.

In choosing to do my senior thesis project on costume design for the stage, I received handson training for the profession I plan to pursue. Over the course of this production, I was able to experience firsthand the entire process of costume design, from reading and researching the script, to sketching, rendering, and actualizing the costumes. I learned how to take the visions and suggestions of the director into consideration as I developed a design concept; I also learned how to accept feedback in a constructive way that enhanced my visions. I discovered the importance of staying flexible in my designs and thus the necessity of the occasional compromise to further the overall visions for the project.

I acquired many practical skills that I will be able to apply in my pursuit of costume design work in the future. I learned how to budget both time and money, how to organize work for a crew and prepare for shopping trips; how to run a costume fitting and a costume parade, take notes during rehearsals, and work with the actors. I also learned how to collaborate with a full design and production team while maintaining the professional respect due in student-faculty relationships. Perhaps more importantly, I learned the value of making decisions and the confidence this could bring.

The skills I acquired during this project have given me a solid foundation upon which to build as I transition from an academic environment to the world of professional theatre. 


\section{APPENDIX}

Selected Materials to Accompany

Costume Design for Tim Robbins'Dead Man Walking 
MEN

Byron Coolie.

Clyde Percy

Prisoner B

Reporter 3

Crystian Wiltshire

.Luis Montoya

Parole Guard

Man 1

Guard Trapp

David Galloway.............. Matthew Poncelet

Devin Ward..................... Troy Poncelet

Eric Knoppkie................ Prisoner A

Parole Guard

Man 3

Sergeant Beliveau

Gary Brice.................Chaplain Farley

Matt Klemenz................Male Guard

Pardon Board Member 1

Walter Delacroix

Mitch Poncelet

Phil Lynch...................Guy Gilardi

Man 2

Governor Fredericks

Warden Hartman

Rich VerWiebe

Hilton Barber

Travis Stolp................ Reporter 2

Earl Delacroix

Xavier Bleuel

Herbie

Pardon Board Member 3

TV Reporter

Pro-death Supporter

Governor's Aide

Polygraph Operator 


\section{WOMEN}

Hannah Greene..............Mirabeau (Pardon Board)

Sister Helen's Mother

Woman 3

Jamie Poncelet

Jennifer Cooper............. Sister Marie Augusta Neal

Visitor to Prisoner B

Lucille Poncelet

Magnolia Hensley.............Reporter 1

Mrs. Delacroix

Woman 2

Nurse

Megan Ward................. Sister Helen Prejean

Renea Brown................Sister Colleen

Tamara Kamara..............Female Guard

Pardon Board Member 2

Hope Percy

Emily Percy

Woman 1

Tia Davis.................... Visitor to Prisoner A Marybeth Percy 


\section{MAKEUP DESIGN}

Below is a list of the general makeup requirements for the actors in the show, as well as special considerations for certain characters. "Street makeup" is jargon for the basic makeup that many women wear on an every-day basis.

\section{MEN}

Design: Conservative, natural

General Requirements: Face powder only for all male cast members.

\section{Special character requirements:}

Prison Guards - clean-shaven or facial hair must be trimmed to a mustache, at most.

Father Farley - white in beard and in sideburns.

Earl Delacroix - white in sideburns.

Matthew Poncelet - Tattoos on arms and left leg: drawn on the actor with Sharpie and set with baby powder and hairspray. Facial hair was clean

Walter Delacroix - corpse makeup for morgue photo to be projected onto screen

\section{WOMEN}

Design: Conservative street makeup

General Requirements: Foundation, concealer, face powder with minimal mascara, eyeliner, eyeshadow, blush, and lipstick.

\section{Special character requirements:}

Hope Percy - corpse and prom makeup for photos to be projected onto screen 


\section{HAIR DeSIGN}

Below is a list of the hairstyles and hairstyle changes in the production.

\section{Hannah Greene}

Mirabeau - low ponytail

Mother - short, gray wig

Woman 3 - low ponytail

Jamie Poncelet - loose around shoulders

\section{Jennifer Cooper}

Sister Neal - tight, low bun

Visitor to Prison $B$ - loose, no accessories

Lucille Poncelet - loose with black headband

\section{Magnolia Hensley}

Reporter $1-$ loose

Mrs. Delacroix - loose

Woman 2 - tied up with headscarf

Nurse - loose with white nurse's cap

\section{Megan Ward}

Sister Helen - low, tight bun; hair color toned down with brown temporary hairspray

\section{Renea Brown}

Sister Colleen - low, tight bun

\section{Tamara Kamara}

Female Guard - low, tight bun

Hope Percy - loose, no accessories

Emily Percy - tied with yellow headscarf

Woman 1 - low ponytail with scrunchie

\section{Tia Davis}

Visitor to Prisoner A - dredlocks braided into bun, tied with headscarf Marybeth Percy - dredlocks braided into bun, no accessories

\section{David Galloway}

Matthew Poncelet - hair cut shorter on sides, longer on top and combed back to create a wave 
Dead Man Walking

\section{Production Timeline for Costumes}

The following is an overview of all events and deadlines for the production. Also included are the major deadlines for the senior honors project.

\begin{tabular}{|c|c|c|}
\hline \multicolumn{3}{|l|}{2013} \\
\hline WED & $\operatorname{Sep} 4$ & Concept meeting with director \\
\hline MON & Sep 16 & Senior Honors Thesis Initiation form and Proposal due \\
\hline WED & Oct 16 & Review rough sketches and research images with supervisor \\
\hline WED & Oct 23 & Present rough sketches and research images to Director \\
\hline THUR & Oct 31 & Production Meeting \\
\hline $\begin{array}{l}\text { MON } \\
\text { TUES } \\
\text { WED }\end{array}$ & $\begin{array}{l}\text { Nov } 4 \\
\text { Nov } 5 \\
\text { Nov } 6\end{array}$ & Auditions and Callbacks \\
\hline FRI & Nov 8 & Casting meeting with Director - discussion of doubling scheme \\
\hline MON & Nov 11 & Casting meeting with Director - revisiting doubling scheme \\
\hline MON & Nov 18 & Rehearsals begin \\
\hline THUR & Nov 21 & Production Meeting \\
\hline MON & Nov 25 & Design Presentation to cast \\
\hline WED & Nov 27 & Thanksgiving Break - no rehearsals or shop work \\
\hline MON & Dec 2 & Preliminary clothing pull from costume stock \\
\hline TUES & Dec 3 & Preliminary accessories pull from costume stock \\
\hline WED & $\operatorname{Dec} 4$ & $\begin{array}{l}\text { Fittings } \\
\text { Shopping - Goodwill }\end{array}$ \\
\hline THUR & Dec 5 & $\begin{array}{l}\text { Production Meeting } \\
\text { Fittings }\end{array}$ \\
\hline FRI & Dec 6 & Fittings \\
\hline MON & $\operatorname{Dec} 9$ & Fittings \\
\hline TUES & Dec 10 & $\begin{array}{l}\text { Fittings } \\
\text { Publicity Photo }\end{array}$ \\
\hline WED & Dec 11 & Fittings \\
\hline THUR & Dec 12 & $\begin{array}{l}\text { Shopping - Walmart } \\
\text { Shopping - Bluegrass Uniforms } \\
\text { Shopping - Goodwill } \\
\text { Shopping - Target }\end{array}$ \\
\hline \multicolumn{2}{|c|}{ Winter Break } & Shopping - Online \\
\hline
\end{tabular}




\begin{tabular}{|c|c|c|}
\hline \multicolumn{3}{|l|}{2014} \\
\hline TUE & Jan 7 & Fittings \\
\hline WED & Jan 8 & Fittings \\
\hline THUR & Jan 9 & Production Meeting \\
\hline FRI & Jan 10 & Run-through rehearsal for lighting designer - attended to compile scene list \\
\hline Mon & Jan 11 & Program bios and special thanks due \\
\hline WED & Jan 15 & Costume Parade \\
\hline THUR & Jan 16 & Production Meeting \\
\hline FRI & Jan 17 & Media shoot for photos and video \\
\hline WED & Jan 22 & $\begin{array}{l}\text { Run-through rehearsal - attended with Wardrobe Master to note quick } \\
\text { changes }\end{array}$ \\
\hline THUR & Jan 23 & Costume Load-In \\
\hline SUN & Jan 26 & $\begin{array}{l}\text { First dress rehearsal } \\
\text { Practice quick changes with crew }\end{array}$ \\
\hline Mon & Jan 27 & Second dress rehearsal \\
\hline TUES & Jan 28 & $\begin{array}{l}\text { Final dress rehearsal } \\
\text { Photo call for designers }\end{array}$ \\
\hline WED & Jan 29 & Opening night \\
\hline FRI & Jan 31 & Deadline for submitting name of student-selected thesis committee member \\
\hline Sun & $\mathrm{Feb} 2$ & $\begin{array}{l}\text { Final performance } \\
\text { Strike }\end{array}$ \\
\hline WED & Mar 5 & Final thesis paper due to all committee members \\
\hline THUR & Mar 20 & Oral thesis defense \\
\hline FRI & Mar 28 & Deadline for submission of thesis approval form and final thesis paper \\
\hline
\end{tabular}




\section{September 4, 2013 - Concept Meeting}

- Discussion of overall impression of play and its effects on us individually

- In-depth discussion and analysis of the play plus my specific interpretation of the play's purpose and its intended affect on audience

- Cast size limit set to 18 actors, doubling and tripling of roles is certain

- Time period: play will be kept in the period (1980s)

- Season: not mentioned or referred to directly in script; may be fall or winter if based off real events; most important that all characters' costumes reflect the same season

- Director's overall vision: the play should begin far away and build towards the final execution scene as being the most realistic and most personal; costumes should help towards that goal if possible; costumes should also help clarify distinctions between characters since so much doubling/tripling will occur

- Director's requests for costumes: costumes should be realistic and should reflect the character (not a lot of "glitz" in this show); audience should not be able to guess Sister Helen's occupation from her clothing

- Preliminary design plans: don't overcomplicate, limit one costume per character/role; minimize complete costume changes and maximize effects of accessories

\section{October 23, 2013 - Rough Sketches and Research Images}

- Presentation of research images for all characters plus pencil sketches of costume options for select characters

- Discussion of proposed designs

- Director's suggestions:

- consider less flashy, less "east-Coast" design for Gilardi

- consider less Western influence for Montoya, perhaps retain just one of proposed elements

- consider dressing Father Farley in all black to emphasize his traditional nature

- consider slacks with blouse and sweater for Marybeth Percy

\section{November 8, 2013 - Casting}

- Discuss possibilities for casting

- Help director troubleshoot doubling/tripling scheme 
- Discuss possibility of having a "tomboy" type Poncelet sister instead of brother

November 11, 2013 - Casting

- Continue discussing options for doubling/tripling scheme 


\section{Account of Production Meetings}

The following is an account of the production meetings as they pertain to costume design. Production meetings occur on predetermined Thursdays, beginning usually at 1:00 pm and lasting 30-45 minutes. The following parties were included in all meetings:

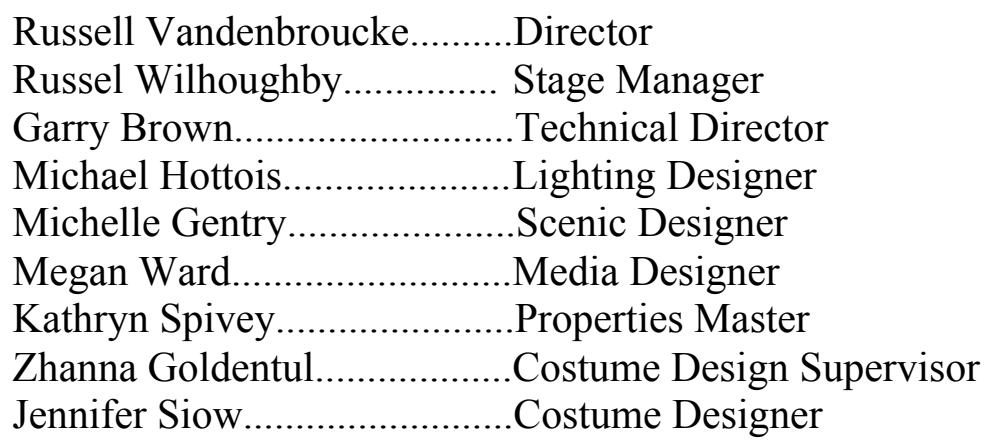

\section{October 31, 2013}

- Rehearsals: scheduled Mondays through Fridays 7:00-10:00 pm; breaks will be taken accordingly for Thanksgiving and Winter Break

- Publicity photo: will include Sister Helen and Matt Poncelet

- Research tattoo options for Matt

- Look into a wig for Sister Helen

\section{November 21, 2013}

- Tattoos for Matt Poncelet: there should be several tattoos on the arms only (none on the neck); the less tattoos present, the larger each tattoo should be

- Set design: the set will be painted in greys; the original stage floor will be a darker grey than the built platform; the back wall will be grey with white graffiti for Act I and a cinderblock pattern for Act II

- Script change: scenes will be shifted so that Governor Fredericks appears before Warden Hartman; how this will be accomplished is not yet decided

- Design presentation to cast scheduled for Monday, November 25, 7:00 pm

\section{December 5, 2013}

- No new issues with costumes

- Publicity photo scheduled for Tuesday, December 10: Actors called at 11:30 am to be ready for photo shoot at 12:00 pm; will take place in the Thrust theatre 


\section{January 9, 2014}

- New cast member added: 11 year-old Devin Ward will play Troy Poncelet; a costume needs to be assembled for this character

- Sister Neal will no longer appear in silhouette

- Sister Helen requires pockets for both acts

- Character distinction: director requests a hat to help with distinction between Walter Delacroix and Mitch Poncelet

- Costume parade notes: Timeline is 6:00 call, 6:30 go; two actors will arrive at 7:00 pm due to class (Megg and Magnolia)

- Media shoot scheduled for Friday, January 17: photos and videos to be used on projector screens during the show will be taken from 2:00-6:00 pm; schedule coordinated between myself, Megg, and Russell

\section{January 16, 2014}

- No new issues with costumes

- This production meeting mainly served as the Properties review

\section{January 23, 2014}

- Running time of show: Act II - 65 minutes; Act II - 55 minutes

- Discuss necessity for separate changing and waiting area for underage actor

- First Dress Rehearsal: schedule set for call and go times; rehearsal will run from 2:00 pm to 9:00 pm

- Second and Final Dress Rehearsals: tentative schedule set: 6:30 pm call, 7:30 go

- Photo call for designers set to follow Final Dress rehearsal 


\section{January 10, 2014 - Lighting Run-through}

- 7:00 pm to $10: 00 \mathrm{pm}$

- Compiled list of French scenes and basic blocking for the entire play (Appendix p. 35)

- Actors moving a lot of furniture pieces, carrying stools, chairs, table on and off stage

- Measurements taken for new cast member (Troy Poncelet)

- Costume issues noted:

- Sister Helen does a lot of moving, sitting and kneeling - consider giving her a practice skirt

- Talk to Matt Poncelet about haircut - short on sides, longer on top; provide images

- Some male actors will need to shave facial hair for their characters

- Father Farley needs white in hair for age

- Sister Helen's Mother needs more age - pull wig and glasses on chain

- Pull sports coats to add to Male and Female Guards to become part of the Pardon Board

- Provide suit jacket to Props to put in garment bag used in Act II

- Pull slippers for Matt's walk to the execution chamber

- Pull entire costume for Troy Poncelet

- Costume questions:

- Does a prison chaplain wear a cross?

- What number should be tattooed on Matt's left leg?

- Will the Reporters be seen during interview with Governor?

\section{January 15, 2014 - Costume Parade}

- 6:00 pm to 8:30 pm

- All sewing and alteration notes to be completed by costume shop crew

- Costume notes:

- Writing on Hope's class pin needs to be more visible

- Marybeth Percy needs '80s style purse and pendant necklace instead of cross

- Nurse needs watch

- Woman 1 needs a new costume, hair scrunchie

- Governor Fredericks needs fancy, shiny black dress shoes

- Male Guard and Female Guard need black, lace-up character shoes

- Troy Poncelet needs new shoes, converse-style "Chucks"

- Mitch Poncelet needs short, pull-on boots

- Nurse and Warden Hartman need nametags

- Hilton Barber needs new sweater vest with lower neckline and more color

- Reporter 1 needs neck scarf; shirt needs to be dyed grey

- Mr. Delacroix needs glasses, tie clip, tie, and sports coat

- Sisters Helen, Colleen, and Neal - adjust chain lengths on crosses

- Sister Helen's Mother needs a new costume - longer dress or slack and sweater

- Sergeant Beliveau needs larger belt

- Mrs. Delacroix needs a new top, less flashy 
- Father Farley needs a different jacket with longer sleeves and Catholic stole

- Man 2 needs a different ball cap

- Visitor to prisoner B needs large 80s style earrings

- TV Reporter needs tie clip, watch and new sports coat

\section{January 22, 2014 - Second Run-through}

- 7:30 pm to $9: 30 \mathrm{pm}$

- Made list of all costume changes for entire play (Appendix p. 38)

- Noted exits, entrances, and approximate times for quick changes

- Major quick change concerns will be:

- (21/2 minutes) Mirabeau exits down stage left and enters as Mother upstage left

- (2 $1 / 2$ minutes) Pardon Board Member 1 exits down stage left and enters as Walter Delacroix downstage right

- (2 $1 / 2$ minutes) Pardon Board Member 2 exits downstage left and enters as Hope Percy downstage right

\section{January 26, 2014 - First Dress Rehearsal}

- 2:00 pm - Actors and crew called to run quick changes: Mother, Walter, Hope

- 2:30 pm - Remaining cast called

- 3:45 pm - All actors in full costume and makeup for top of the show; meet in theatre for briefing with Wardrobe Master and designer

- 4:00 pm - Rehearsal begins

- 8:30 pm - Designer's notes to cast

- All sewing and alteration notes to be handled by the costume shop crew

- General notes:

- Explain all-black attire requirement to stagehands

- Speak to director about changing some blocking for Sister Helen since she is in a skirt

- Costume notes:

- Hope needs dark tights; all earrings need to be converted to clip-ons

- Mr. Delacroix needs a different tie, perhaps blue or with blue pattern

- Tattoo visible on top of actor's foot (Magnolia Hensley) - try darker knee-highs or adhesive Band-Aid to cover up

- Sister Helen needs a pocket added to inside of burgundy suit jacket; hair color needs to be toned down

- All prison guards need watches

- Lucille Poncelet needs a plain headband

- Clyde Percy needs a sports coat

- Herbie needs elastic laces in Chucks shoes to quicken costume change

- Woman 2 needs headscarf

- Sister Colleen needs foundation garment

- Polygraph Operator needs a larger labcoat

- Matt needs more tattoos on lower forearms; calf tattoo needs to be larger and lower on the leg

- Marybeth Percy's hair needs to be styled differently (actress has dredlocks) 
- Prisoner B and Reporter 3 need black elastic laces on boots and character shoes to aid this costume change

\section{January 27, 2014 - Second Dress Rehearsal}

- 6:15 pm - Actors and crew called to practice quick change: Matt, Sgt. Beliveau, Guard Trapp

- 6:30 pm - Remaining actors called

- 7:30 pm - Rehearsal begins

- 10:00 pm - Designer's notes to cast

- Costume notes:

- Sister Helen needs handkerchief to be preset in patterned jacket pocket

- Doctor's lab coat needs a medical insignia pin like Nurse

- Sewing and alteration notes were handled by the costume shop crew

- Many actor notes from this rehearsal regarding how to wear certain garments

\section{January 28, 2014 - Final Dress Rehearsal}

- 6:30 pm - Actors and crew called

- 7:30 pm - Rehearsal begins

- 10:00 pm - Rehearse curtain call

- 10:30 pm - Photo call for designers

- All notes from this rehearsal were for actors; no sewing or design notes made during this rehearsal. 
Dead Man Walking

\section{FrenCH SCENES \& BLOCKING}

French scenes begin and end with the entrance and/or exit of one or more characters. These scenes were recorded by me during a rehearsal and are not defined in the script.

\section{ACT I}

1) Opening Tableau - all actors on stage except for Matt Poncelet

2) Helen tutors Herbie, downstage left; Montoya speaks to Helen downstage right

3) Helen alone on stage for monologue

4) Helen speaks with Montoya; Matt upstage in spotlight

5) Male prison guard collects Helen's metal objects, stage left gutter

6) Female prison guard scans Helen, stage right gutter

7) Helen meets with Father Farley, upstage right at desk

8) Helen visits Matt in prison, along stage left side of platform

- Prisoners A and B also have visitors, these pairs flank Helen and Matt

9) Helen discusses possum at night, bed rolls onto stage, upstage left

10) Sister Colleen comforts Helen

11) Montoya gives Helen Matt's file, downstage center

12) Megg speaks as desk and radio are brought onstage

13) Reporters enter and speak while Helen and Colleen examine file material on desk

- Reporter 1 upstage center

- Reporter 2 stage right gutter

- Reporter 3 stage left gutter

14) Radio DJ announces execution

15) Matt calls Helen - Helen downstage center, Matt in spotlight, upstage center

16) Helen brings Hilton Barber to Matt in prison - same process, same guards as before

17) Hilton Barber and Helen meet with Matt in prison - at table near stage left side of platform

18) Helen visits Lucille Poncelet, stage right gutter in front of audience seating

19) Helen visits Matt, talk about his father - same visitation table near stage left side of platform

20) Lucille breaks down talking about her son, downstage right

21) Pardon board hearing

22) Helen confronts her doubts

- Mother and Sister Colleen speak upstage left

- Hope and Walter speak downstage right in gutter

23) Helen visits Earl Delacroix at home, stage left gutter in front of audience railing; Walter enters upstage left in blue spotlight

24) Helen meets with Father Farley, upstage right at desk

25) Helen meets with Matt, discuss racism - Matt shackled but loose in visiting area delineated by platform, Helen outside this area on original stage

26) Helen visits Clyde and Marybeth Percy, downstage right 
- Emily enters upstage left, speaks to mother, sits on edge of stage to watch stage left projector screen

27) TV Reporter interviews Matt; interview is mimed in center of stage while filmed interview is projected on screens

- Helen stands in stage right gutter, watching interview on stage right screen

- Emily remains seated on edge of stage to watch interview on stage left screen

28) Helen visits Matt in prison, Matt shackled but loose on platform

29) Helen and Colleen discuss funeral arrangements for Matt, stage left

30) Herbie visits the Helen and Colleen, downstage left

31) Helen and Earl Delacroix attend a support group meeting for victims of homicide, participants sit in circle, downstage center

- Support group consists of Man 1, 2, and 3 and Woman 1, 2, and 3

32) Vigil and protest outside of prison, opposing sides convene in stage left and stage right gutters

- Stage left gutter: Anti-death penalty group: Helen, Colleen, Lucille, Hilton Barber

- Stage right gutter: Pro-death penalty: all members of support group plus Pro-death

Supporter

\section{END OF ACT I}

\section{ACT II}

1) Helen meets Guard Trapp and Sergeant Beliveau, downstage left

2) Helen visits Matt in his death house cell, delineated by platform

3) Farley confronts Helen and Helen faints, downstage left

4) Nurse and Sgt. Beliveau treat Helen, downstage right

5) Colleen show Helen the suit she found for Matt, upstage left

6) Helen speaks onstage alone, downstage center

7) Clyde and Marybeth Percy enter to speak in blue light, upstage left

8) Hilton Barber calls Helen, stage right gutter

9) Mother consoles Helen, upstage left

10) Helen visits Matt in his cell, discuss Bible

11) Helen and Barber meet with Governor Fredericks

- Helen and Barber stand in downstage center gutter

- Gov. Fredericks stands with aide on platform, in spotlight

- Reporter 3 films Gov. Fredericks, this is a live feed to the projector screens

12) Helen climbs into bed and sleeps, upstage left

- Bed is rolled on stage by Hope, Walter, Mother, and Father Farley (all hiding behind headboard)

13) Helen visits Matt in his cell

14) Colleen speaks, spotlight on stage right gutter 
15) Polygraph Operator enters, administers test to Matt, upstage left corner of platform

16) Hilton calls Helen, spotlight on Hilton, downstage right

17) Helen speaks to Beliveau, downstage left

18) Helen meets with Warden Hartman at desk, downstage right gutter

19) Family visits Matt at death house, semicircle downstage center

- Helen, Guard Trapp, and Sgt. Beliveau present

- Warden Hartman ushers family out, stage left exit

20) Helen visits Matt after his last meal

21) Warden delivers bad news to Matt and Matt talks to Barber on phone, upstage right

22) Helen confronts Farley, downstage left

23) Sgt. Beliveau fetches Helen back to Matt

- Matt enters with left leg cut off jeans and white T-shirt only

- Tattoos visible

24) Helen moves downstage left, speaks to Sgt. Beliveau, and prays

25) Matt returns from phone call to family and confesses to Helen; Matt remains in cell, Helen stays outside

26) Nurse is escorted across stage by Guard Trapp and Sgt. Beliveau, enter stage right, exit upstage left behind false wall

27) Helen steps outside while guards come to shackle Matt

- Matt's boots are removed and replaced with slippers

28) Matt is escorted from cell, upstage right, to the execution gurney (offstage)

- Warden Hartman assists guards

- Father Farley waits upstage left, wears stole

29) Matt returns strapped into gurney; family and witnesses enter for execution

30) Helen monologue, downstage center

31) Herbie visits Helen, delivers box with Matt's boots and Bible

32) Helen meets Earl Delacroix at chapel, upstage right

END OF PLAY 
Characters for the top of Act I (Opening Tableau)

\begin{tabular}{|l|l|l|l|}
\hline ACTOR & CHARACTER & ACTOR & CHARACTER \\
\hline Hannah & Mother & Byron & Clyde Percy \\
\hline Jennifer & Sister Neal & Crystian & Luis Montoya \\
\hline Magnolia & Mrs. Delacroix & David & Matt Poncelet \\
\hline Megg & Sister Helen & Devin & Troy Poncelet \\
\hline Renea & Sister Colleen & Eric & Sgt. Beliveau \\
\hline Tamara & Emily Percy & Gary & Father Farley \\
\hline Tia & Marybeth Percy & Matt & Walter Delacroix \\
\hline & & Phil & Gilardi \\
\hline & & Rich & Hilton Barber \\
\hline & & Travis & Earl Delacroix \\
\hline & & Xavier & Herbie \\
\hline
\end{tabular}

Costume changes from opening tableau into first character

\begin{tabular}{|l|l|l|}
\hline ACTOR & CHANGE OUT OF & CHANGE IN TO \\
\hline Hannah & Mother & Mirabeau \\
\hline Jennifer & Sister Neal & Prison visitor \\
\hline Magnolia & Mrs. Delacroix & Reporter \\
\hline Tamara & Emily Percy & Guard \\
\hline Tia & Marybeth Percy & Prison visitor \\
\hline Byron & Clyde Percy & Prisoner \\
\hline Eric & Sgt. Beliveau & Prisoner \\
\hline Matt & Walter Delacroix & Guard \\
\hline Travis & Earl Delacroix & Reporter \\
\hline Xavier & Herbie & TV Reporter \\
\hline
\end{tabular}

Remaining costume changes for Act I (in sequential order)

\begin{tabular}{|l|l|l|}
\hline ACTOR & CHANGE OUT OF & CHANGE IN TO \\
\hline Byron & Prisoner & Reporter \\
\hline Jennifer & Prison visitor & Lucille Poncelet \\
\hline Byron & Reporter & Clyde Percy \\
\hline Travis & Reporter & Earl Delacroix \\
\hline Eric & Prisoner & Sgt. Beliveau \\
\hline Hannah & Mirabeau & Mother \\
\hline Matt & Guard/Pardon board & Walter Delacroix \\
\hline Tamara & Guard/Pardon board & Hope Percy \\
\hline Crystian & Montoya & Guard Trapp \\
\hline Tamara & Hope Percy & Emily Percy \\
\hline Xavier & TV Reporter & Herbie \\
\hline Crystian & Guard Trapp & Support group \\
\hline Tamara & Emily Percy & Support group \\
\hline Eric & Sgt. Beliveau & Support group \\
\hline Hannah & Mother & Support group \\
\hline Magnolia & Mrs. Delacroix & Support group \\
\hline Phil & Gilardi & Support group \\
\hline
\end{tabular}


Characters for the top of Act II

\begin{tabular}{|l|l|l|l|}
\hline ACTOR & CHARACTER & ACTOR & CHARACTER \\
\hline Hannah & Mother & Byron & Clyde Percy \\
\hline Jennifer & Lucille Poncelet & Crystian & Guard Trapp \\
\hline Magnolia & Nurse & David & Matt Poncelet \\
\hline Megg & Sister Helen & Devin & Troy Poncelet \\
\hline Renea & Sister Colleen & Eric & Sgt. Beliveau \\
\hline Tamara & Hope Percy & Gary & Father Farley \\
\hline Tia & Marybeth Percy & Matt & Walter Delacroix \\
\hline & & Phil & Governor Fredericks \\
\hline & & Rich & Hilton Barber \\
\hline & & Travis & Earl Delacroix \\
\hline & & Xavier & Governor's Aide \\
\hline & & &
\end{tabular}

Costume changes that must occur during Intermission

\begin{tabular}{|l|l|l|}
\hline ACTOR & CHANGE OUT OF & CHANGE IN TO \\
\hline Hannah & Support group & Mother \\
\hline Magnolia & Support group & Nurse \\
\hline Tamara & Support group & Hope Percy \\
\hline Crystian & Support group & Guard Trapp \\
\hline Eric & Support group & Sgt. Beliveau \\
\hline Phil & Support group & Gov. Fredericks \\
\hline Xavier & Herbie & Governor's Aide \\
\hline
\end{tabular}

Remaining costume changes for Act II (in sequential order)

\begin{tabular}{|l|l|l|}
\hline ACTOR & CHANGE OUT OF & CHANGE IN TO \\
\hline Byron & Clyde Percy & Reporter \\
\hline Magnolia & Nurse & Reporter \\
\hline Xavier & Governor's Aide & Polygraph operator \\
\hline Phil & Governor & Warden Hartman \\
\hline Matt & Walter Delacroix & Mitch Poncelet \\
\hline Hannah & Mother & Jamie Poncelet \\
\hline Magnolia & Reporter & Nurse \\
\hline Byron & Reporter & Clyde Percy \\
\hline Matt & Mitch Poncelet & Walter Delacroix \\
\hline Xavier & Polygraph operator & Herbie \\
\hline
\end{tabular}




\section{COSTUME RESEARCH}

\section{Helen Prejean}

Not frumpy, open jacket, skirt, collared shirt, glasses, note that crucifix changes with outfit; perhaps purple or mauve
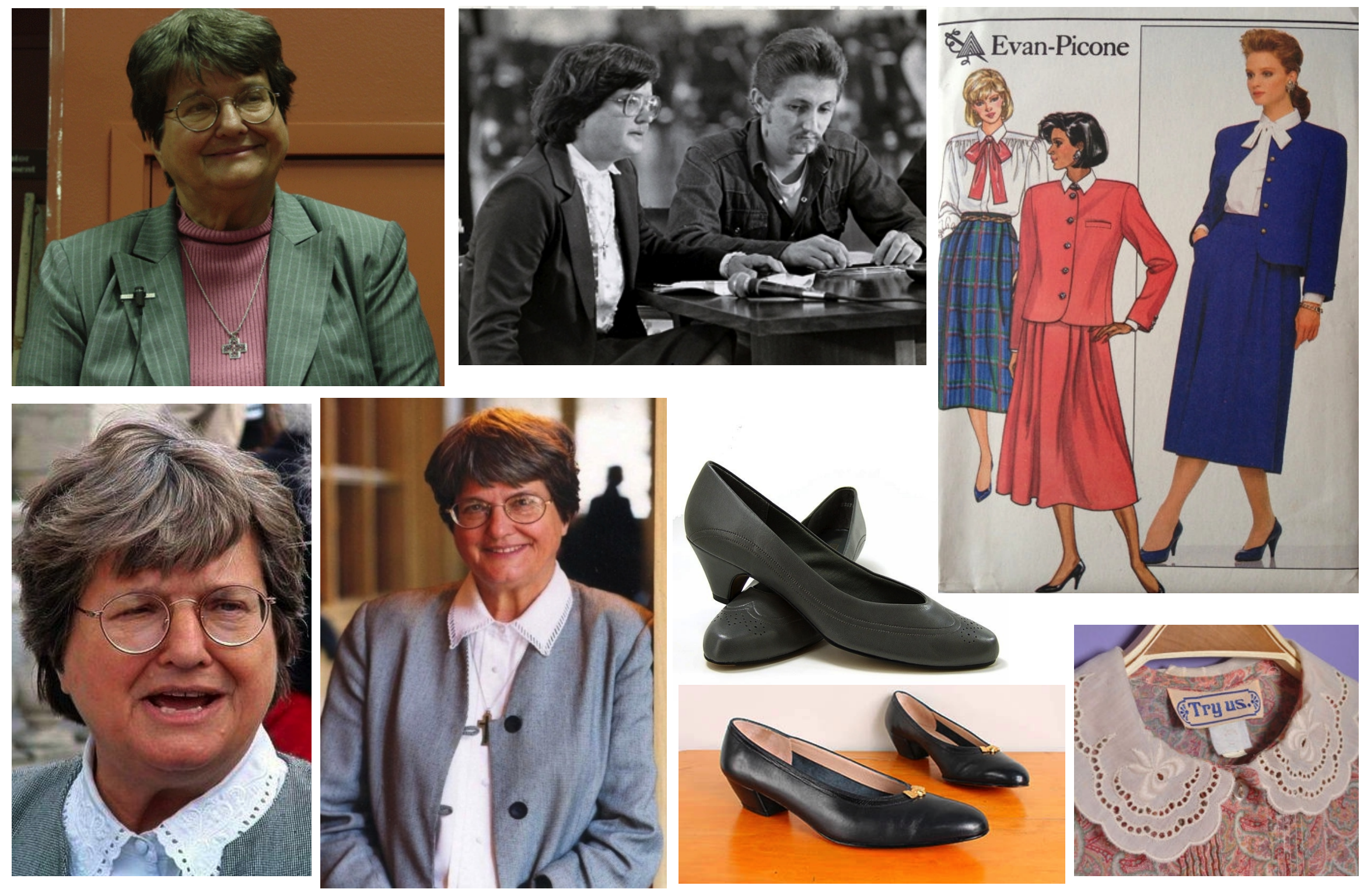


\section{Mother}

Generic older woman, pleated-front dress with long sleeves, wears small cross, grey hair, pearls, pale purple or perhaps purple floral print
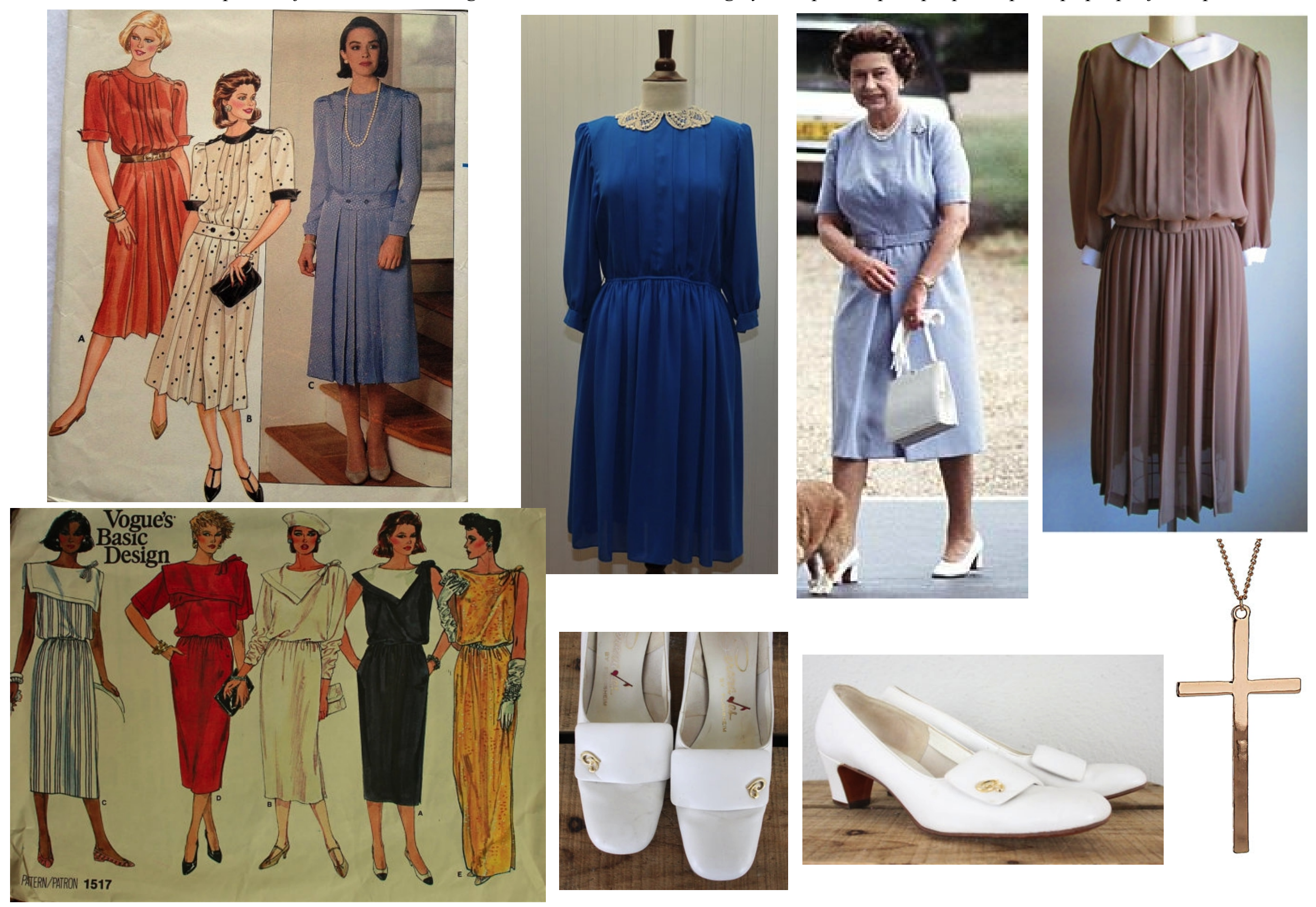
Sister Colleen and Marie Augusta Neal

Nondescript jacket, shirt, and skirt, similar to Prejean but more muted, perhaps darker shades, all wear crosses in various forms, heavy stockings
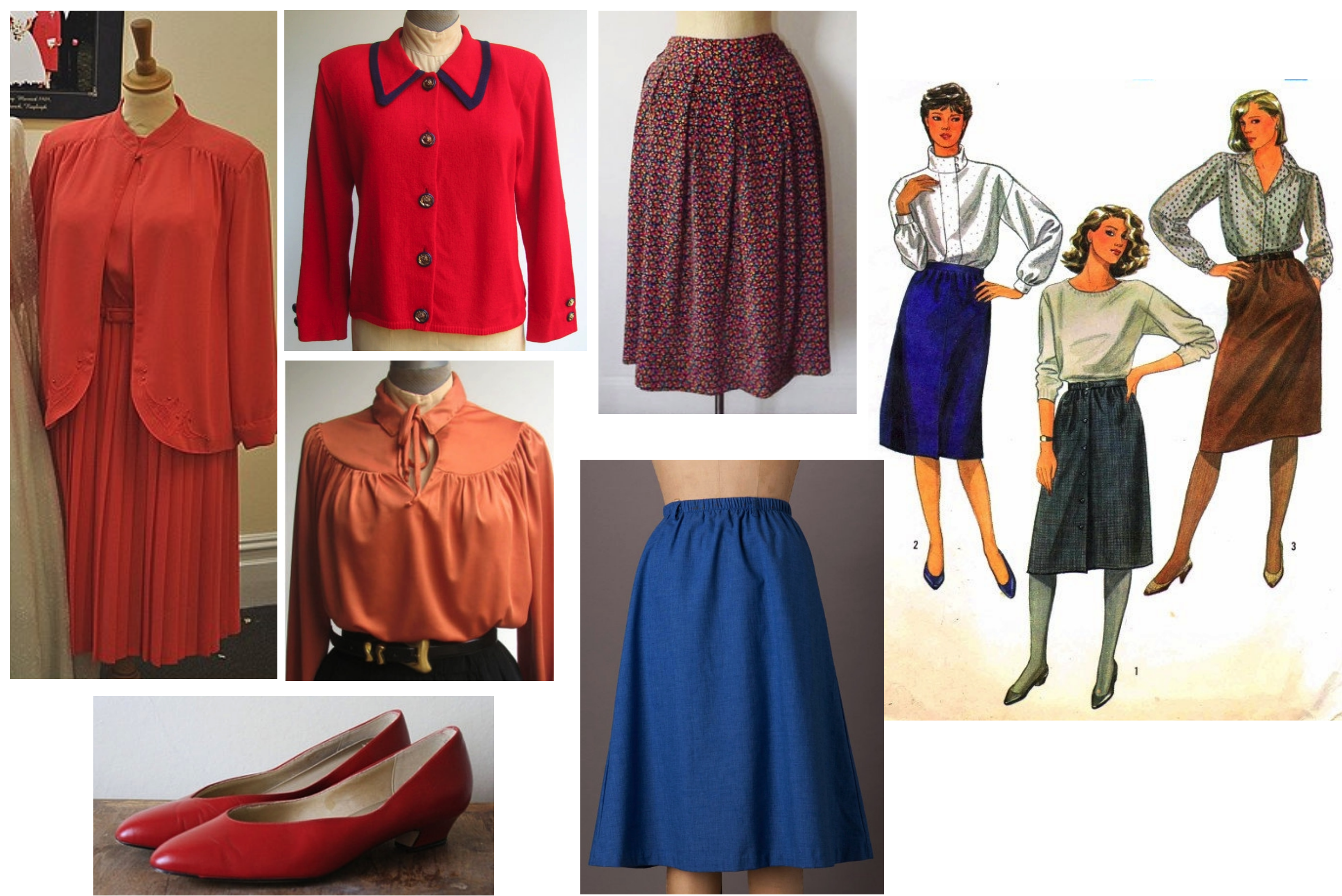


\section{Lucille Poncelet}

Dull windbreaker or oversized fisherman's sweater, black jeans or pants, run-down appearance
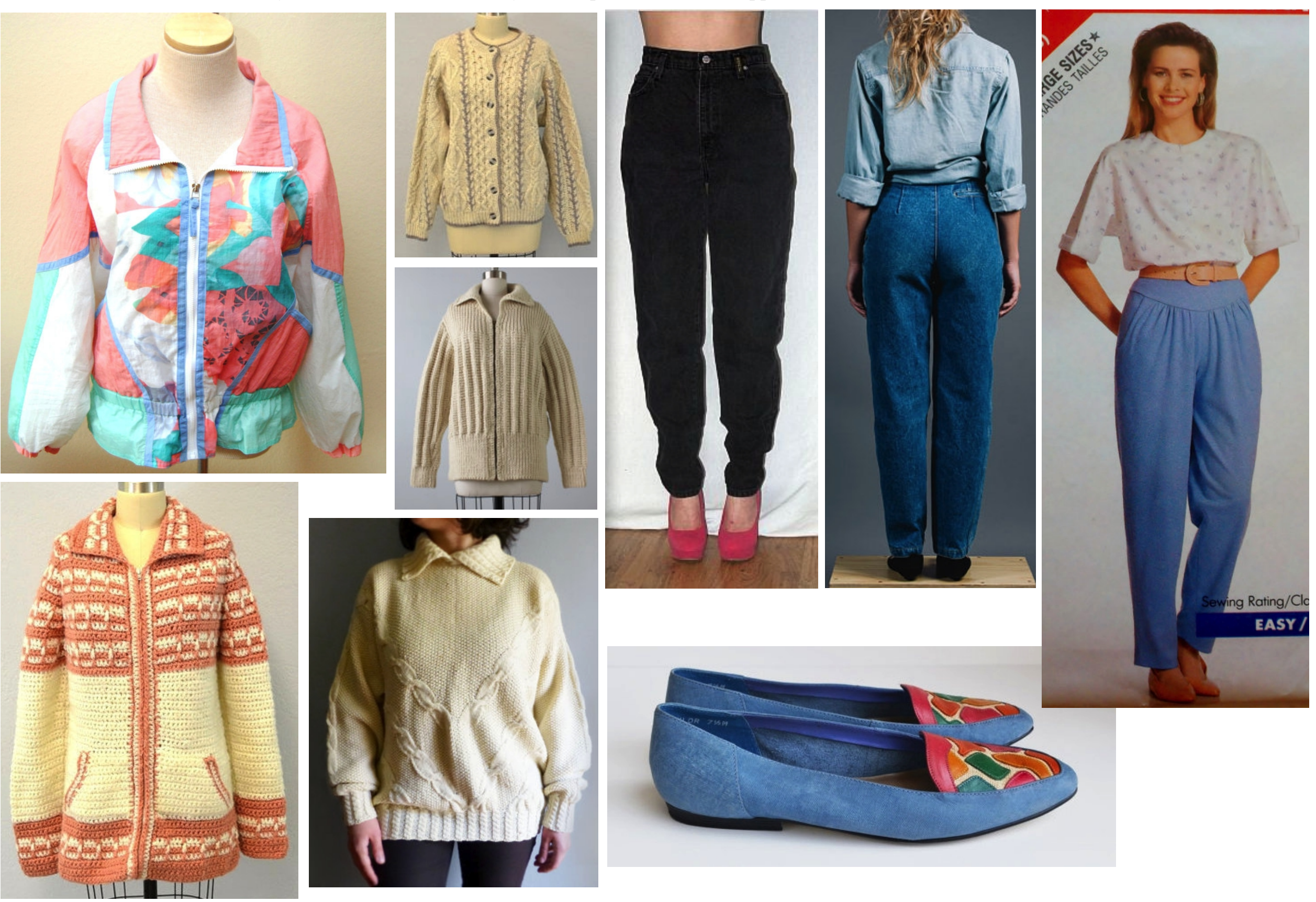


\section{Matthew Poncelet}

LSP prisoner uniform described as: denim or chambray shirts, gray, blue or white sweatshirts, or white t-shirts; also Doc Martens boots

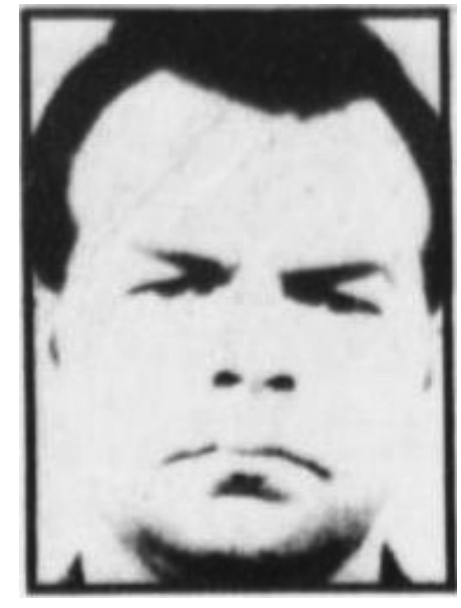

Patrick Sonnier
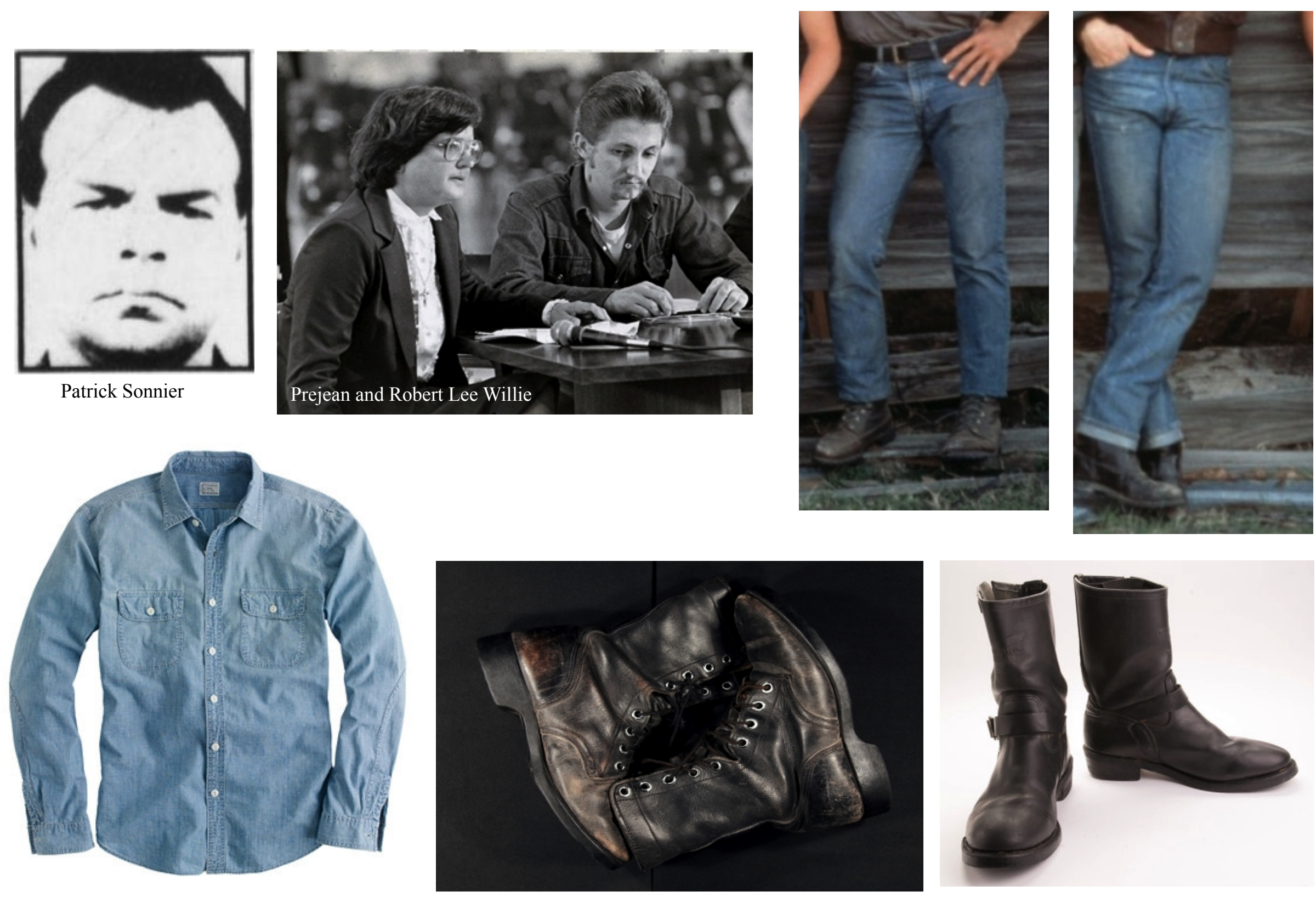
Arms covered in tattoos: swastika, skull, women's names, naked woman on one arm
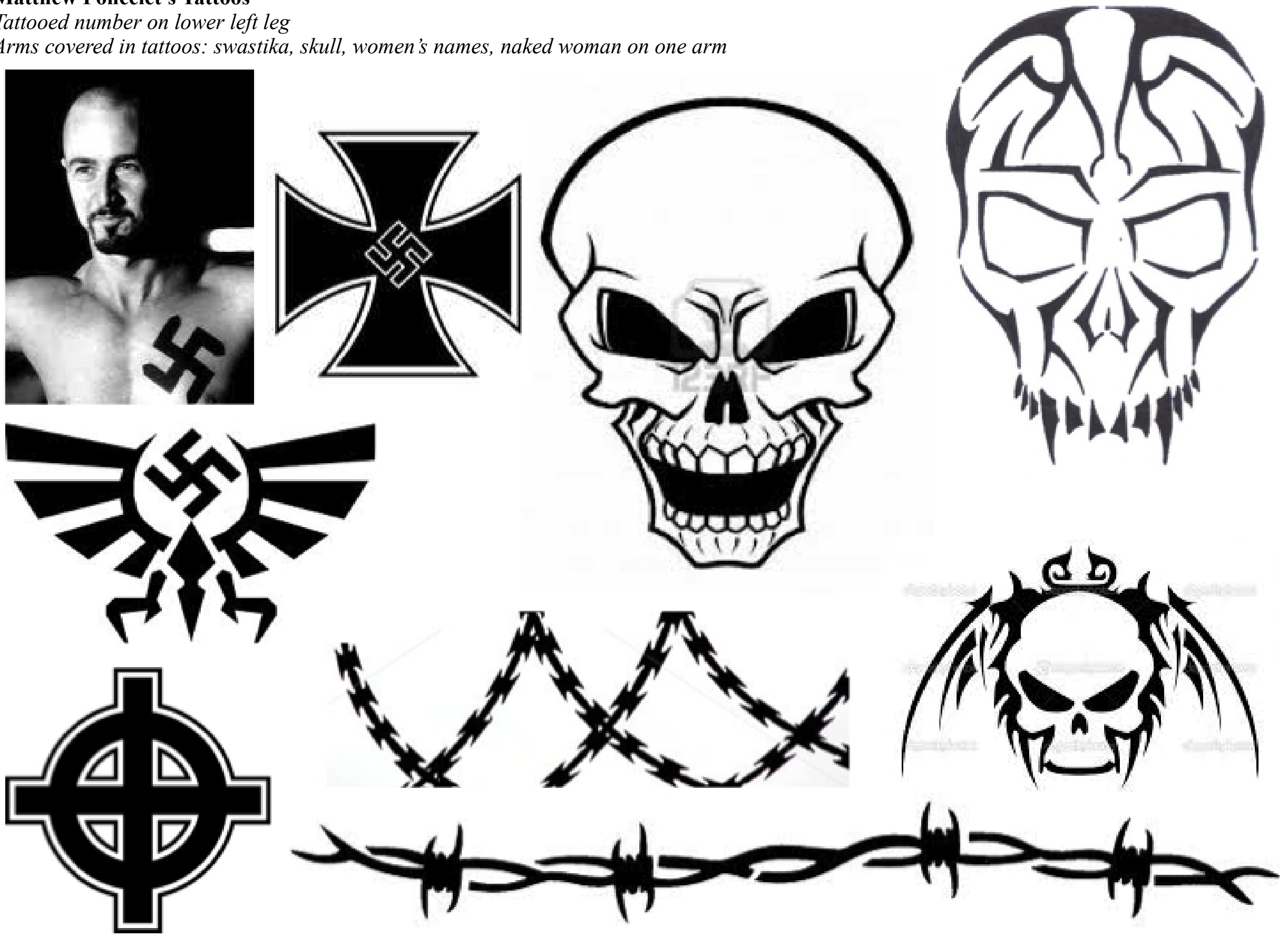


\section{Hilton Barber}

Based on Millard Farmer - Single-breasted suit with vest, coarser fabrics with subtler pattern, plain tie or perhaps bowtie, glasses, 1970 s influence
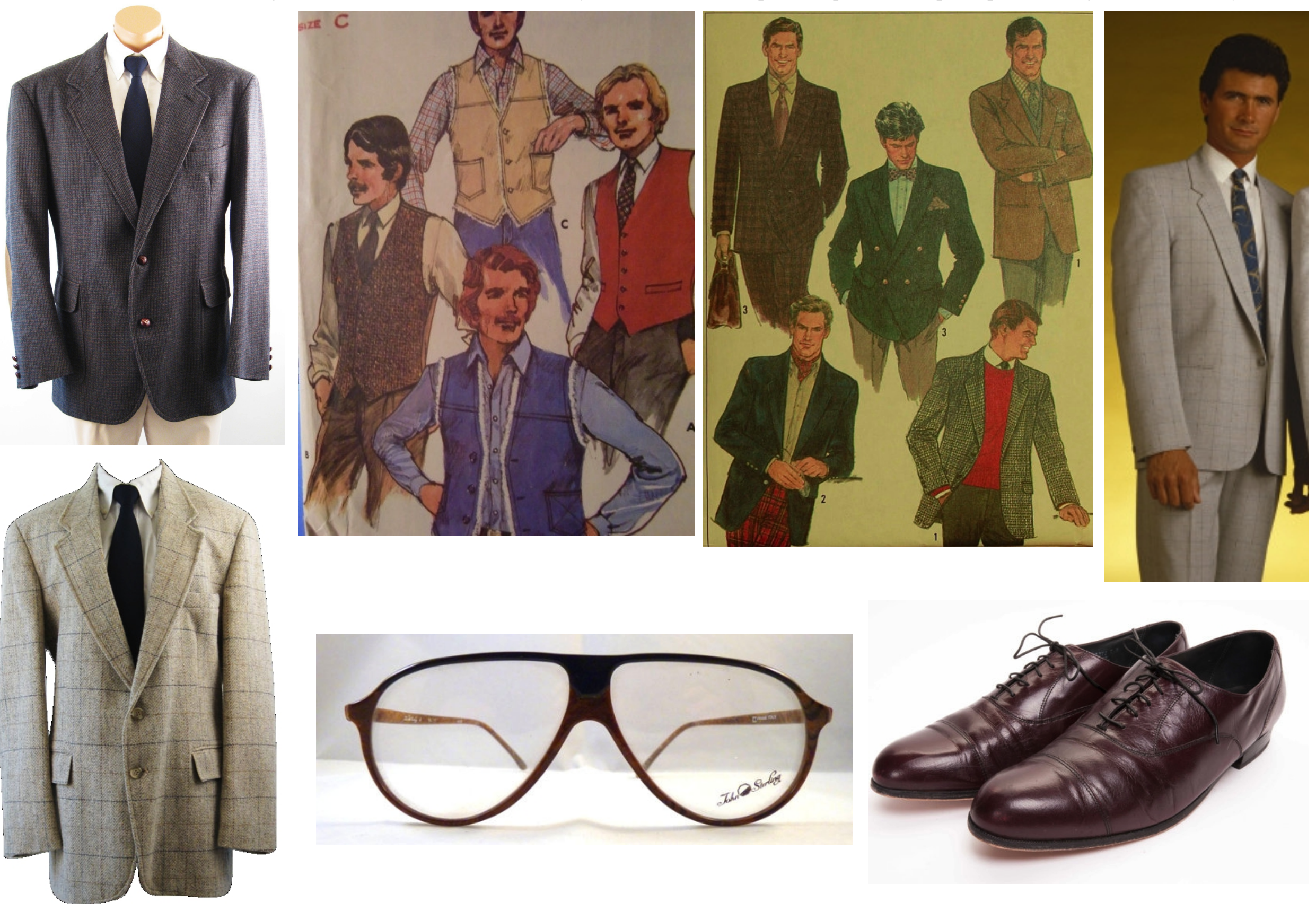


\section{Chaplain Farley}

Stuck in the past (late 1960s accessories), black clerical shirt tucked into black pants, black shoes, dark grey 60s-styled jacket to wear over shirt
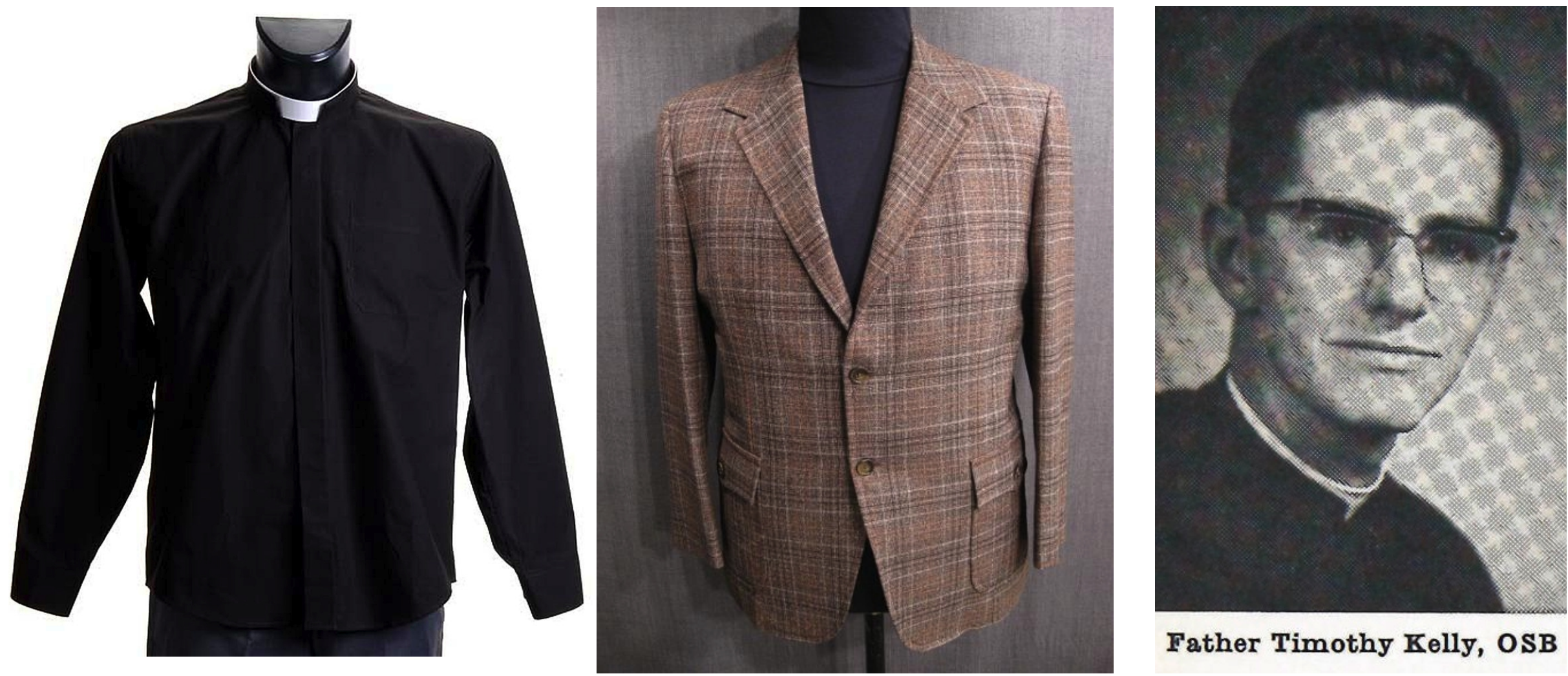

Father Timothy Kelly, OSB
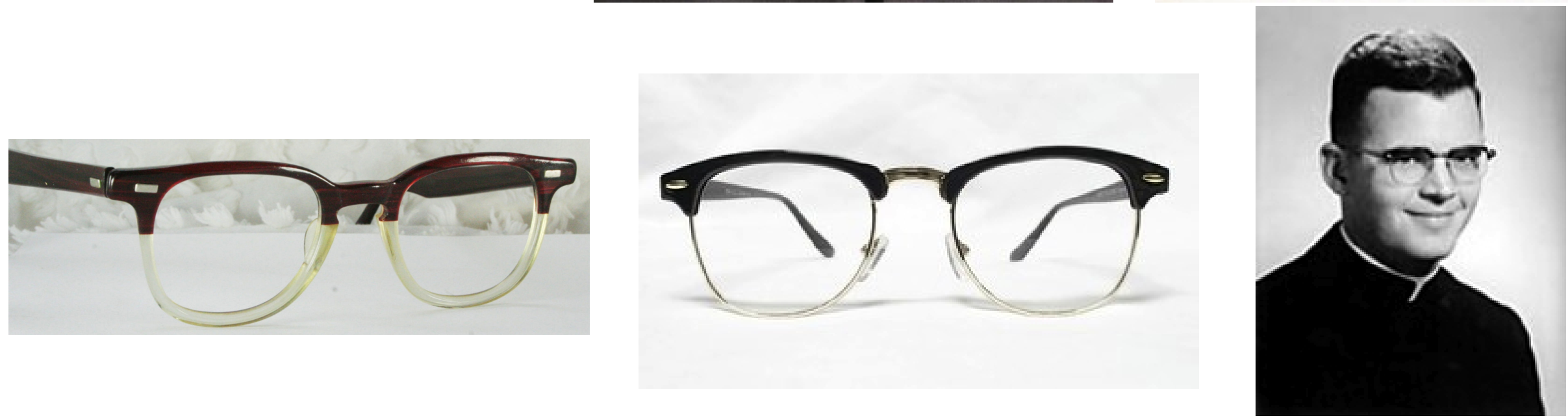


\section{Guy Gilardi}

Flashy DA, silk pinstripe or bold check suit, suspenders, bright tie, slick hair, watch
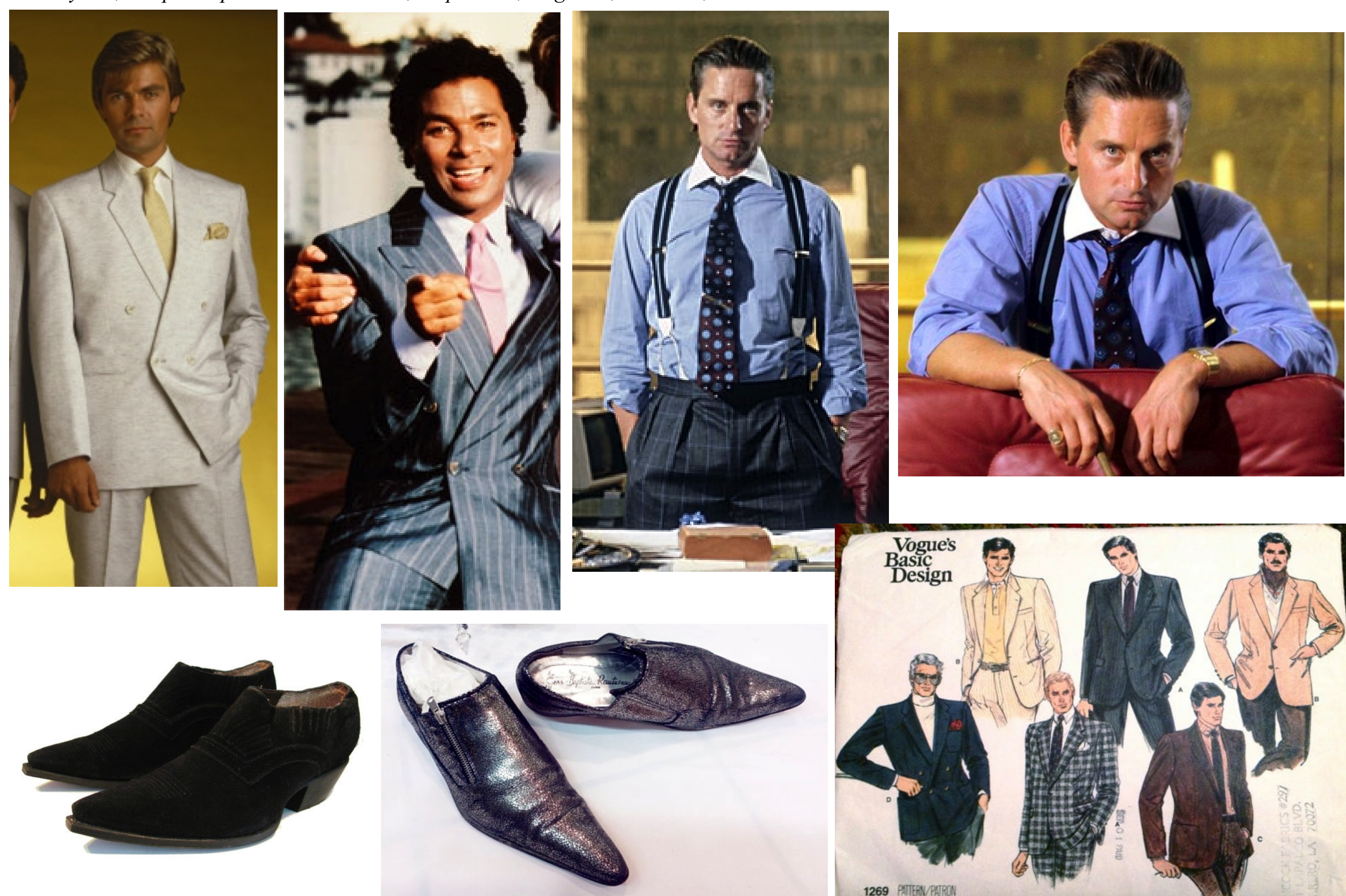

1269 PAITEA PARTON

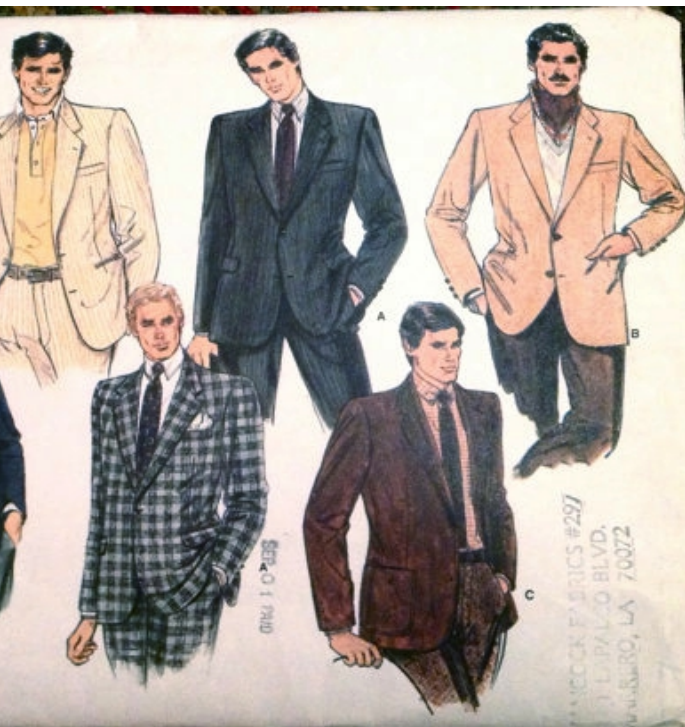


Based on Chava Colon from Prison Coalition - Western influence, works a desk job, jeans, shirt, perhaps string/bolo tie

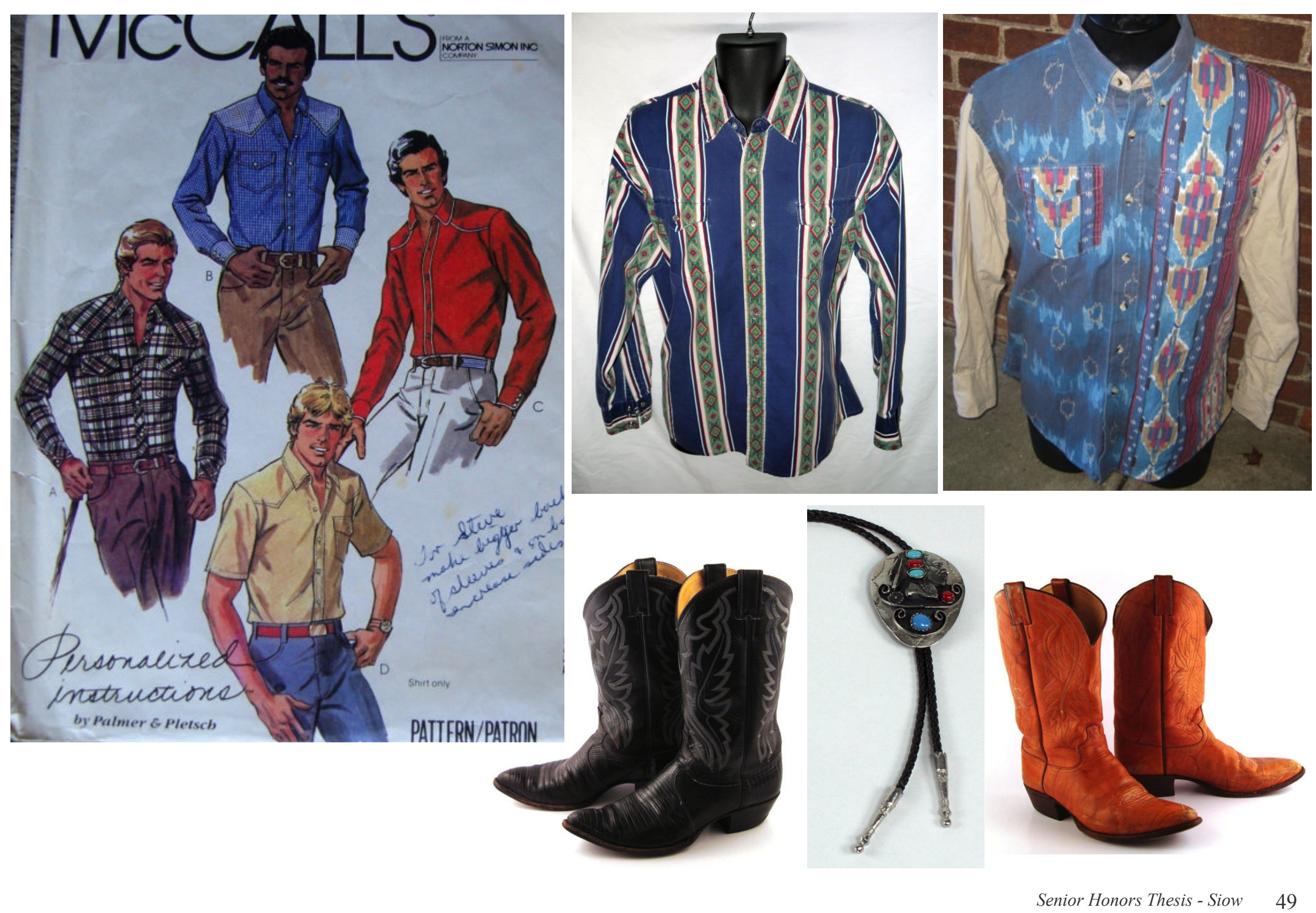




\section{Gov. Fredericks}

Single-breasted, plain lines, white shirt, red tie

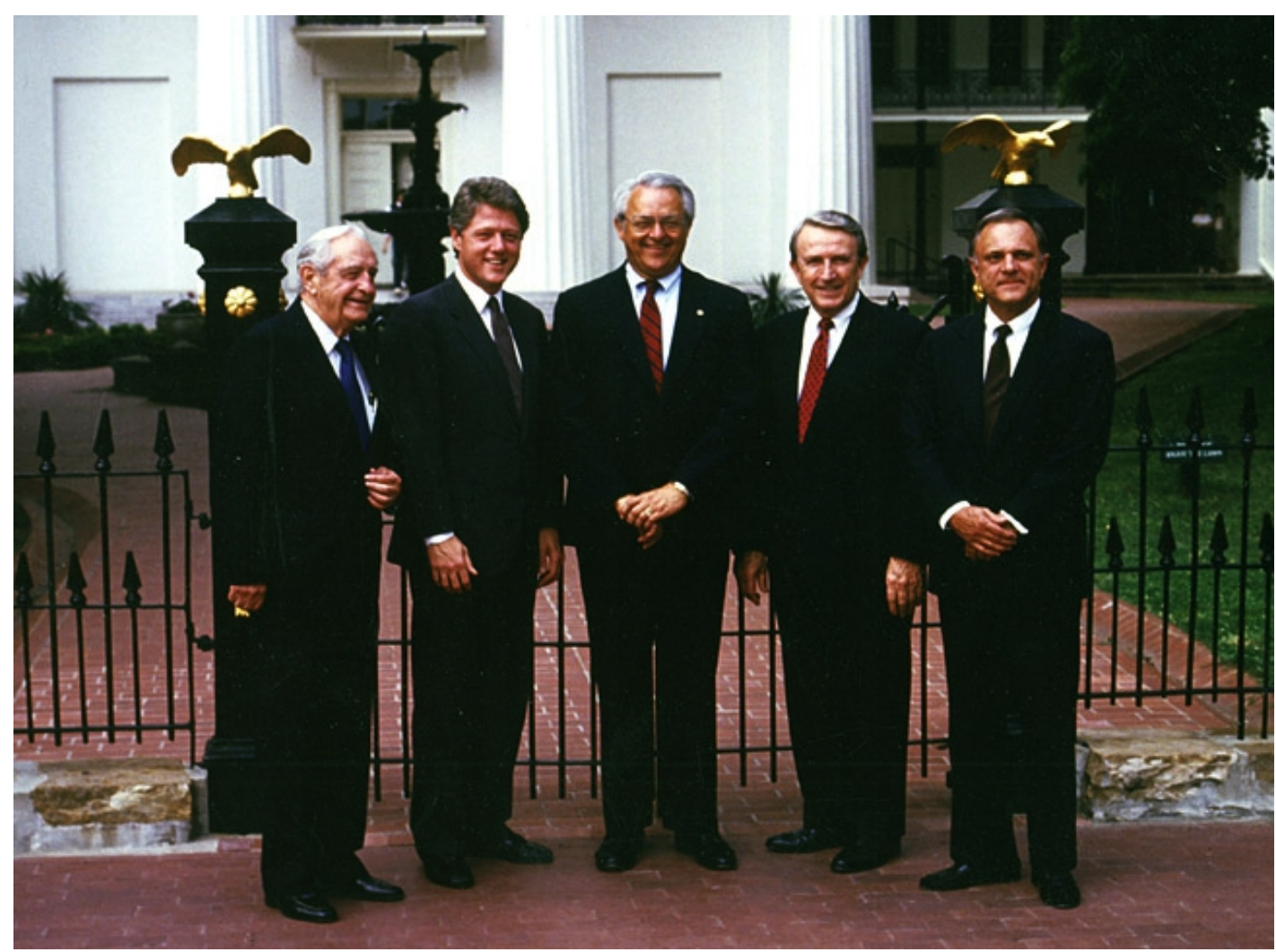

Governor Bill Clinton and former governors Orval Faubus, Frank White, Dale Bumpers, and David Pryor; circa 1980s.

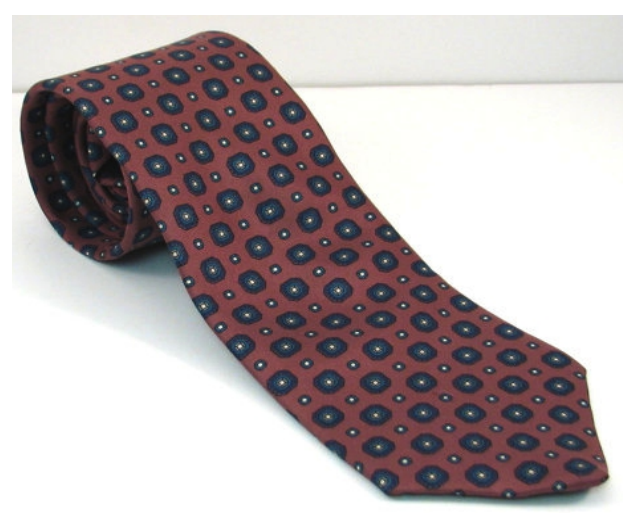

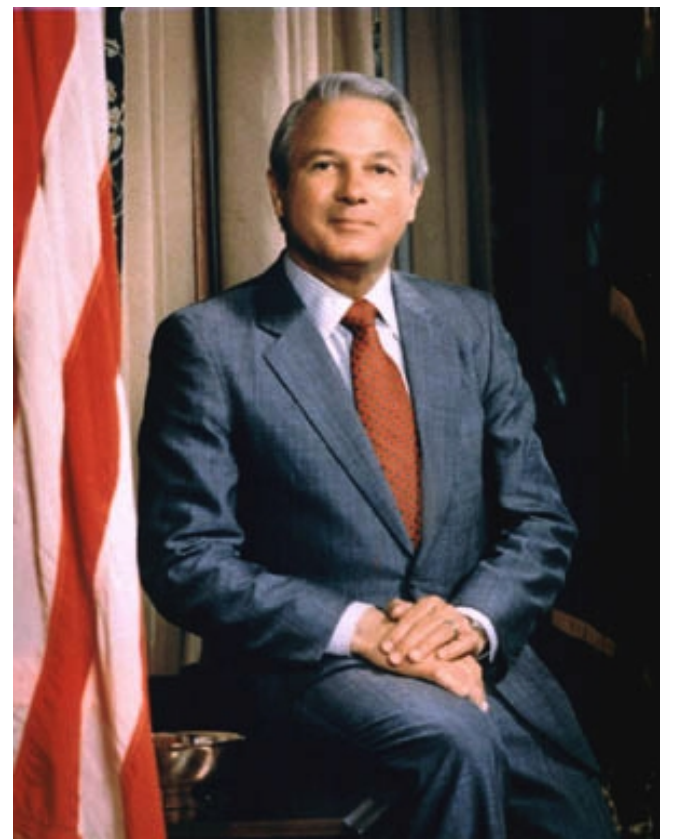

Gov. Edwards of Louisiana

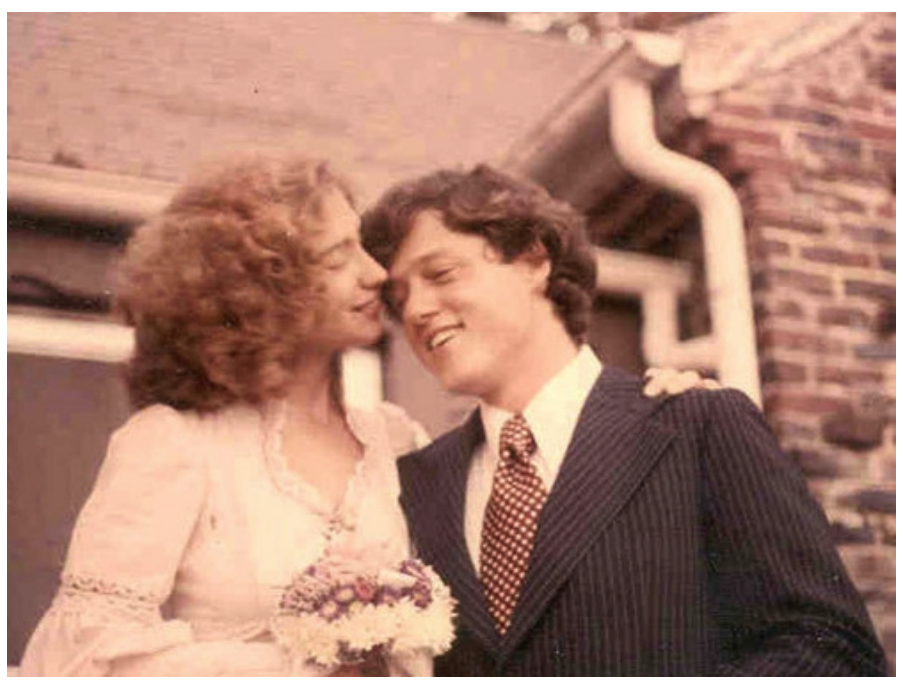

Hillary and Bill Clinton 


\section{Herbie}

High school student, duller/plain jacket or sweater with brightly patterned shirt underneath for end of show, black jeans, white sneakers
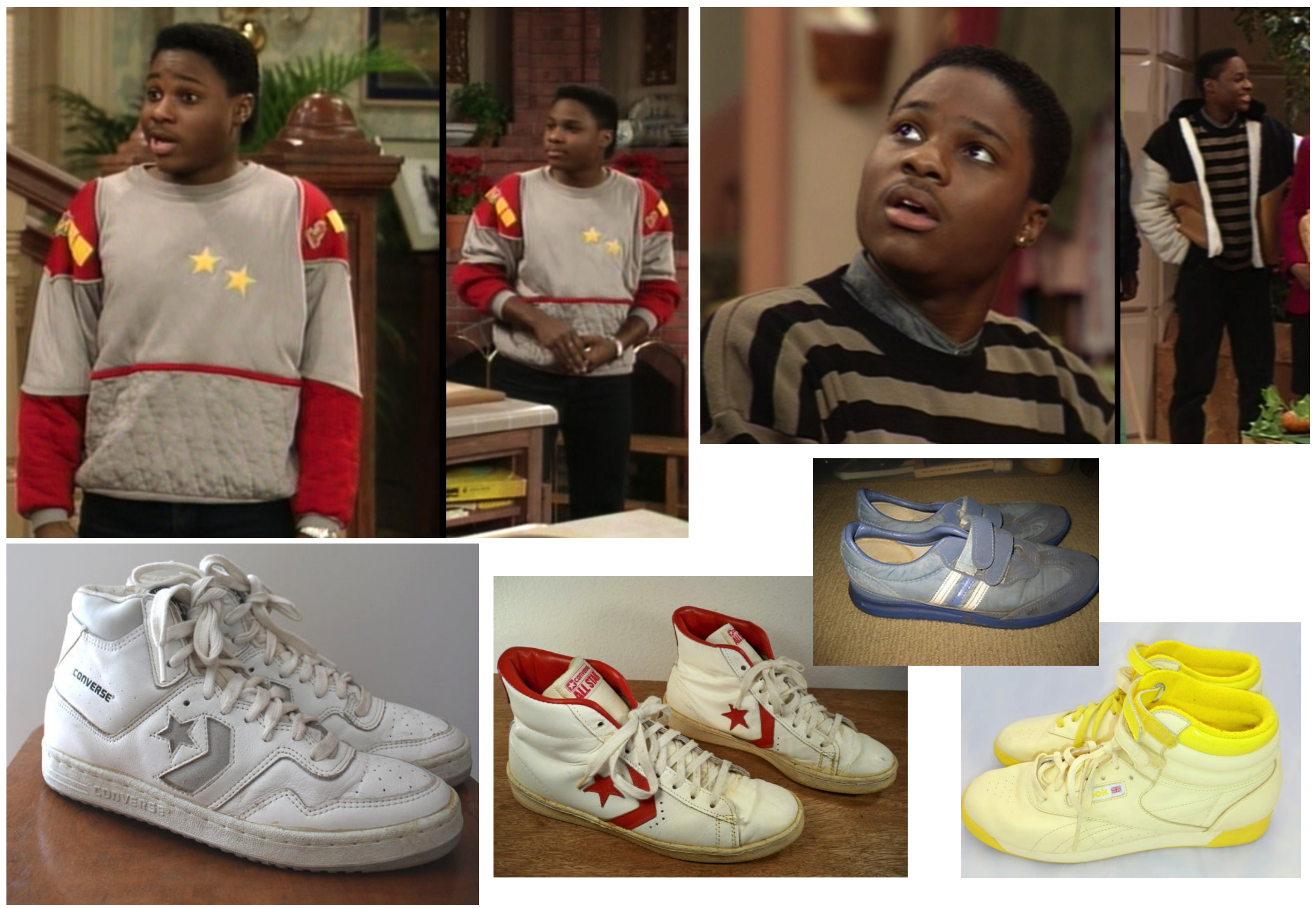
Mitch, Jamie, Troy

Variations of denim, like Matt, but in darker and lighter blues

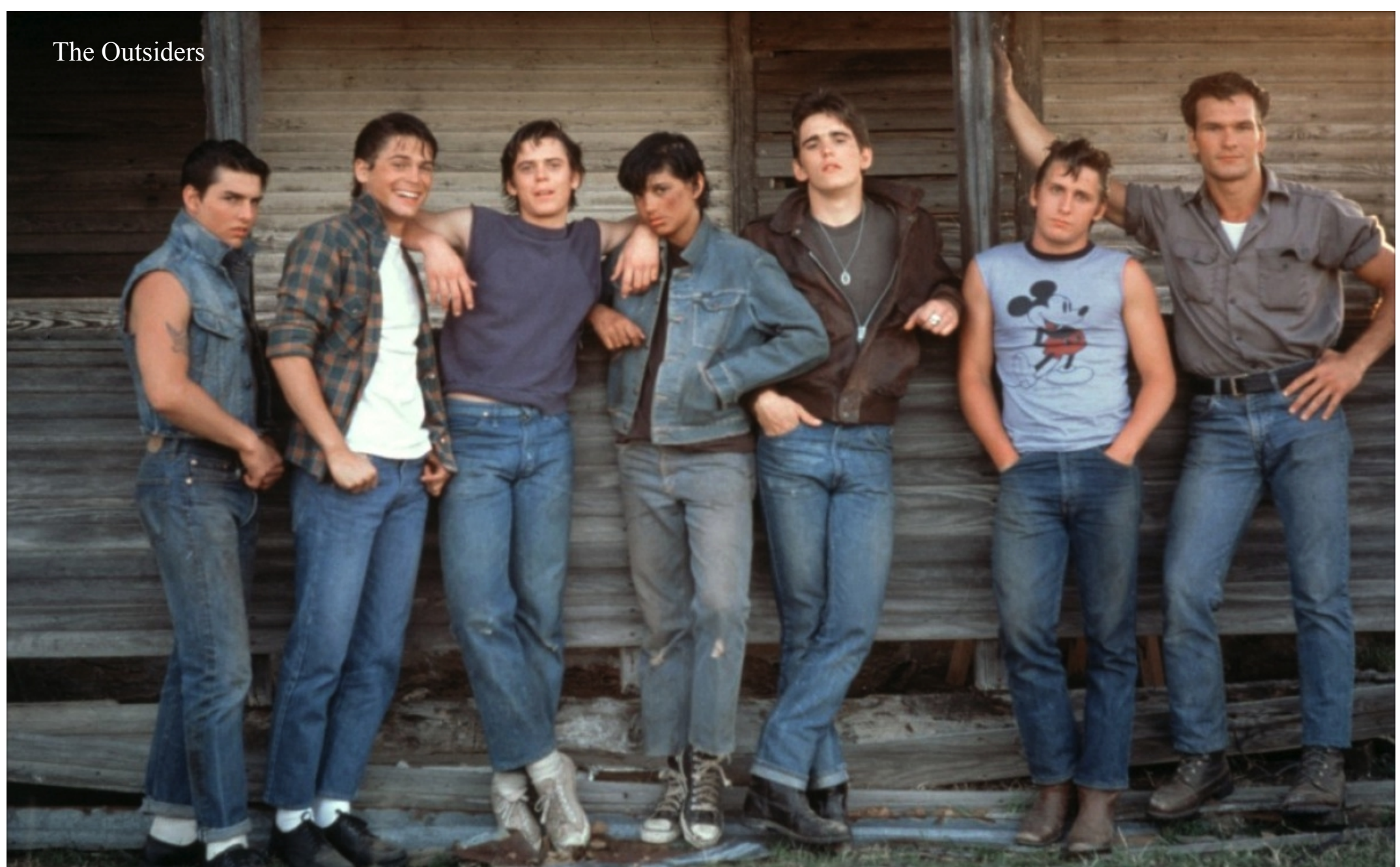


Walter Delacroix \& Hope Percy

Andrew and Clair from the Breakfast Club - Letter jacket or raglan tee, jeans, tennies for Walter; Open-necked blouse, skirt or culottes for Hope, maybe patterned tennies instead of boots, small purse worn on shoulder, small round class pin/button
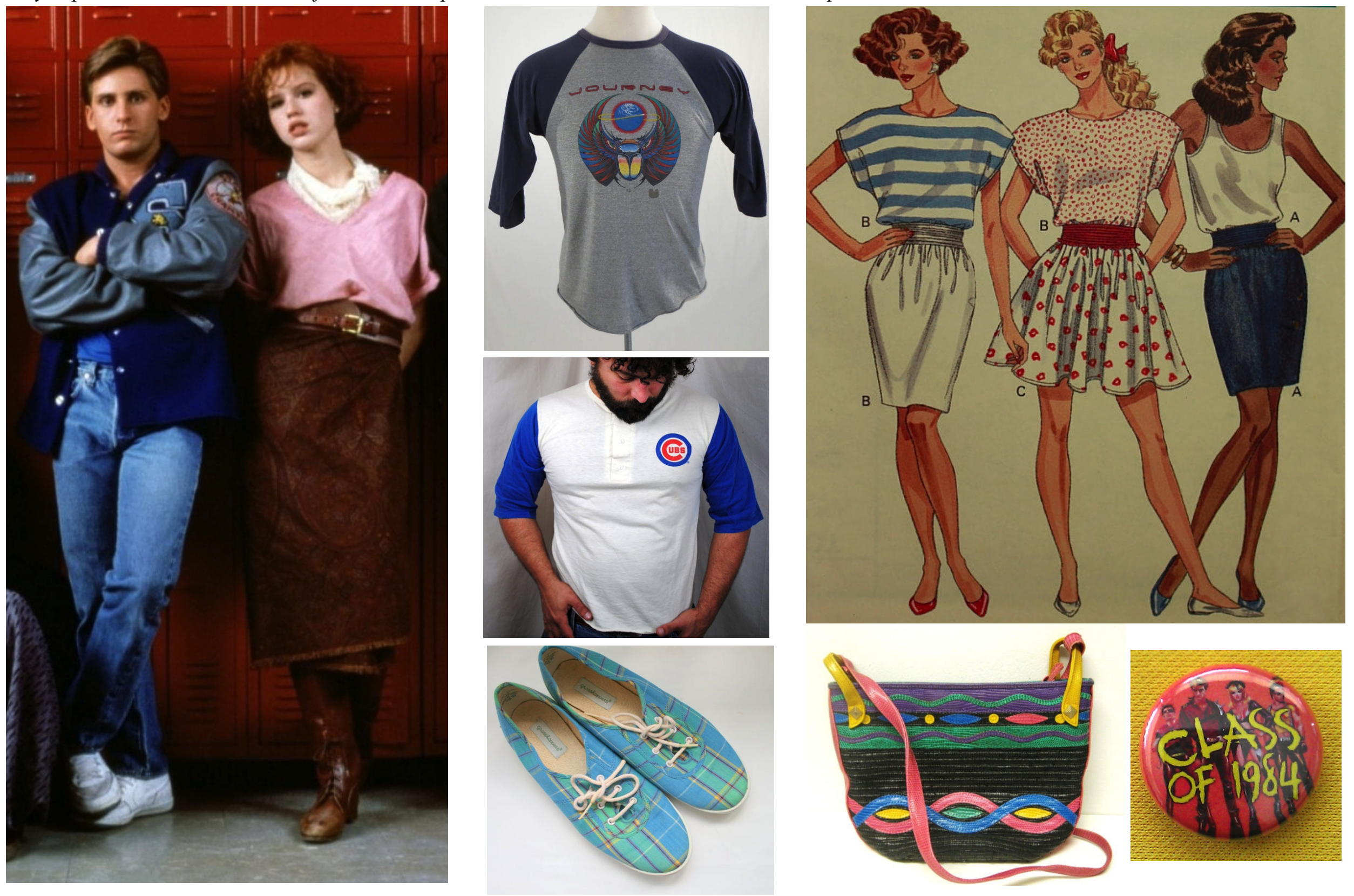


\section{Earl \& Mrs. Delacroix}

Big sweater or member's only jacket, slacks for Earl; dressy sweater over slim skirt or sweater dress, perhaps belted, with light trench coat for Mrs. Delacroix
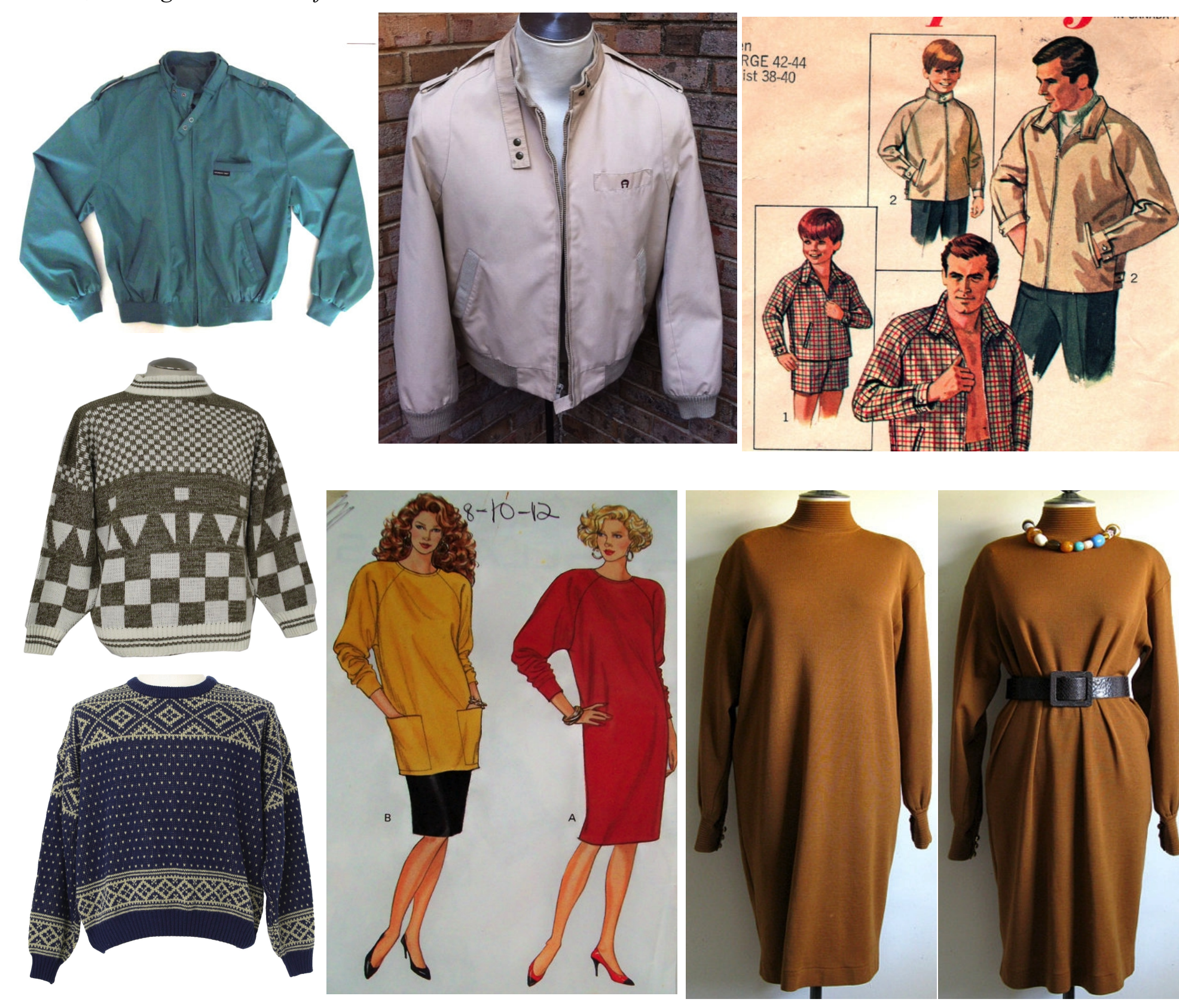
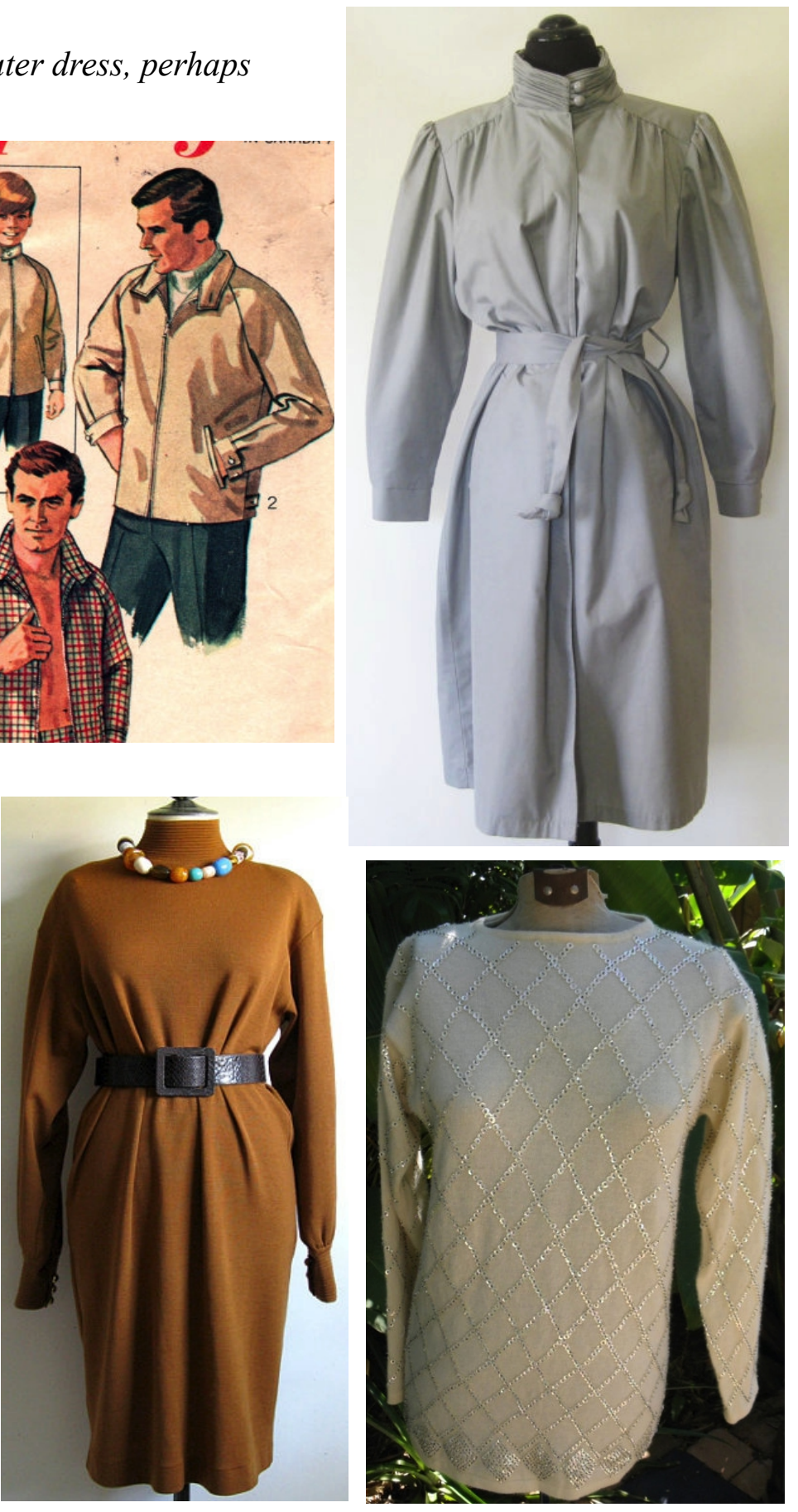
Clyde \& Marybeth Percy

Collared shirt for Clyde in stripes, tucked into pants; blouse and skirt or blousy dress for Marybeth, perhaps with tie at neck
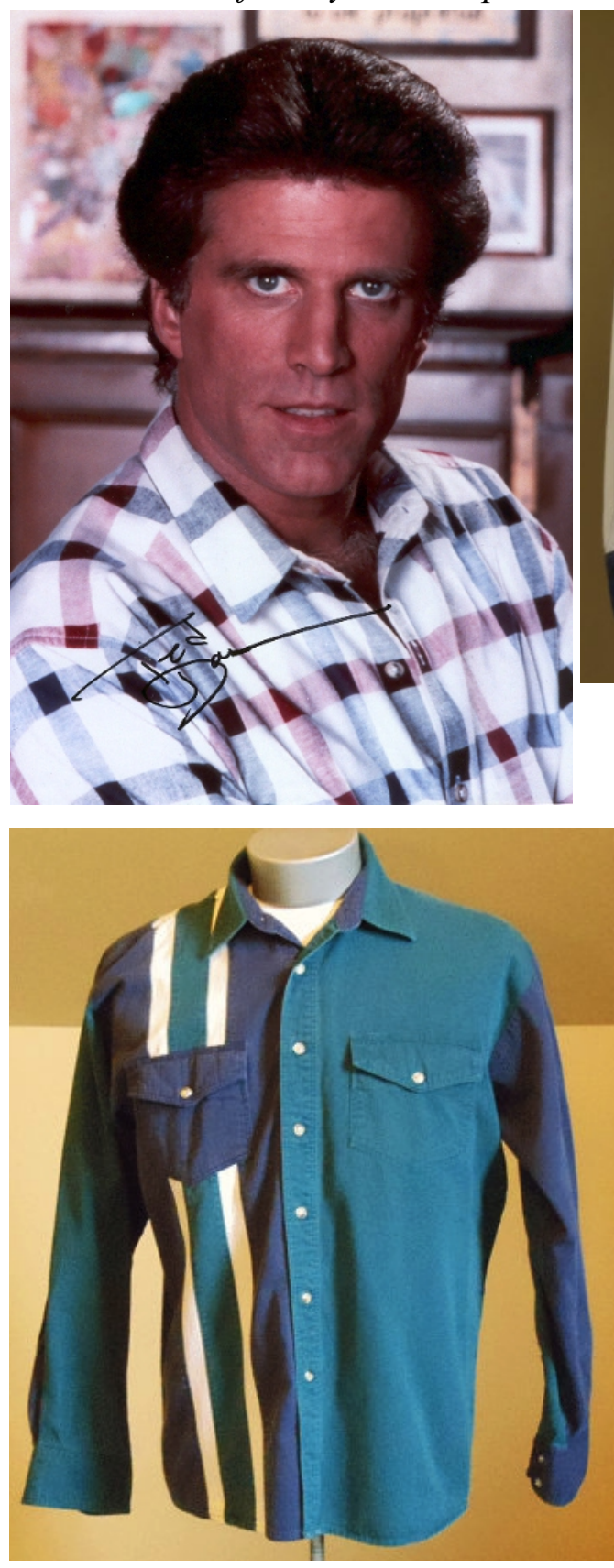
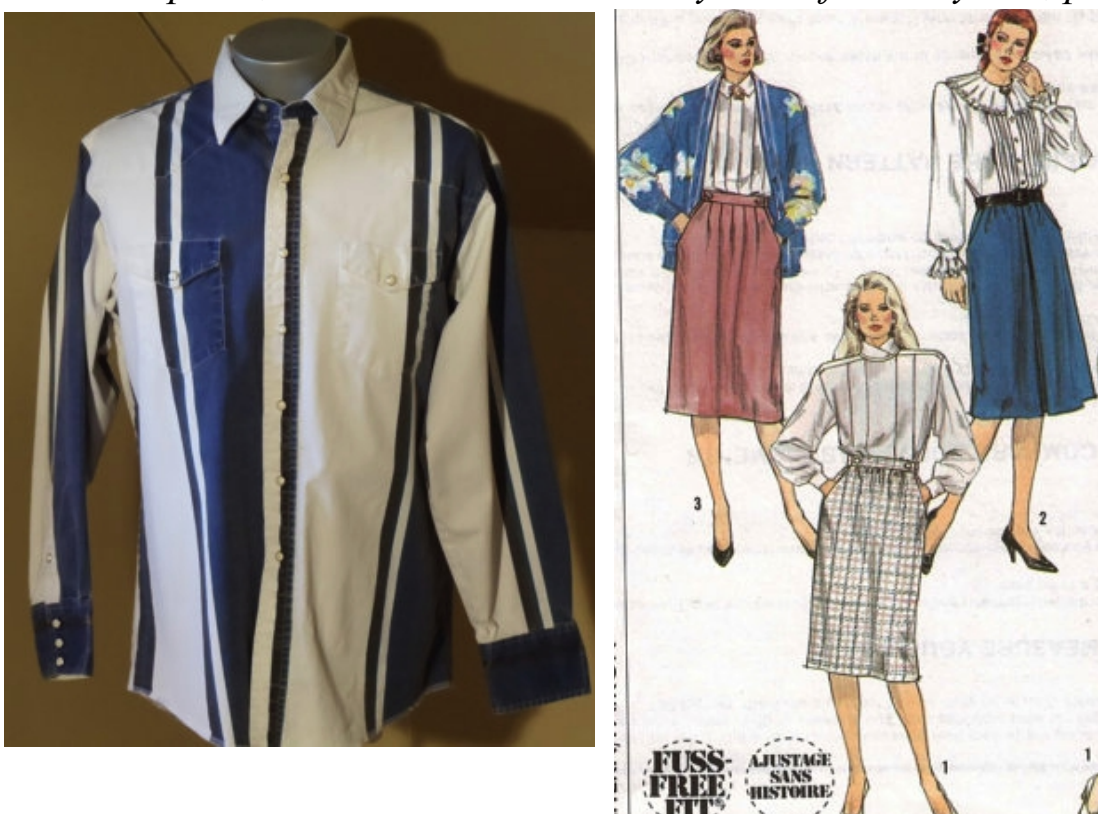

Fis: ustick

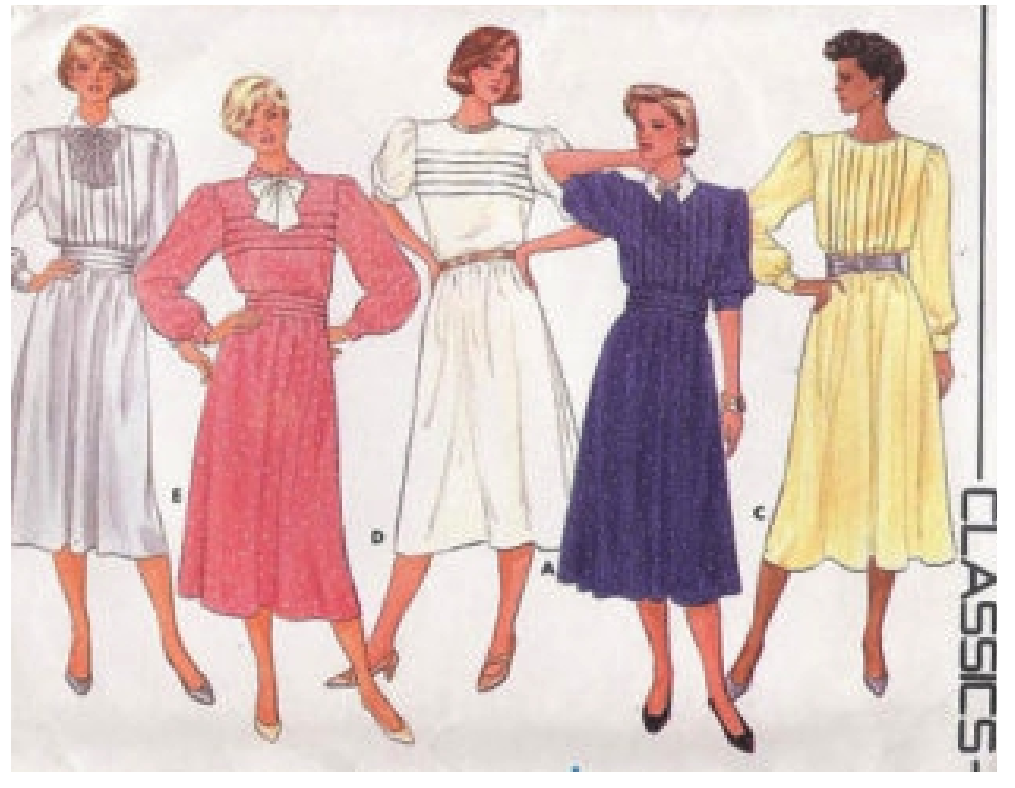

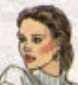

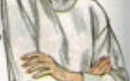

मत.
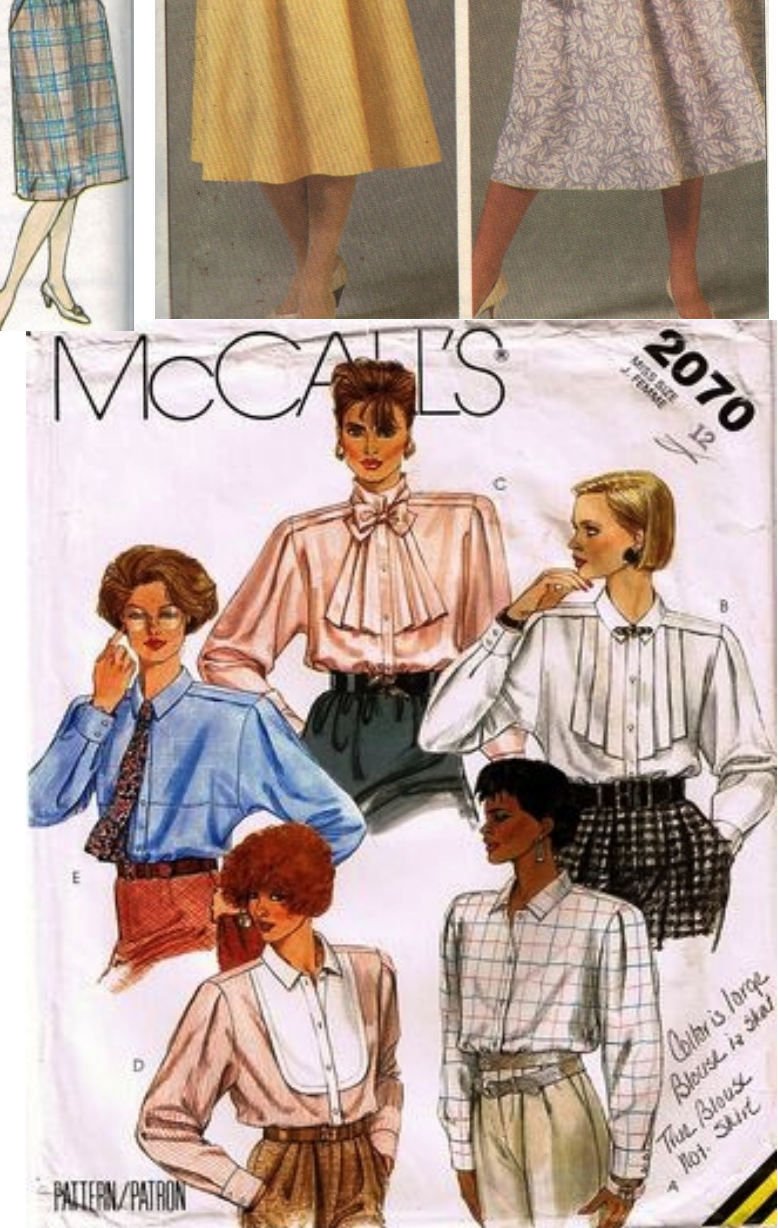

Senior Honors Thesis - Siow 


\section{Emily Percy}

16 years old, "jumper" sweater over stirrup leggings, jellies shoes, headband with bow, girly
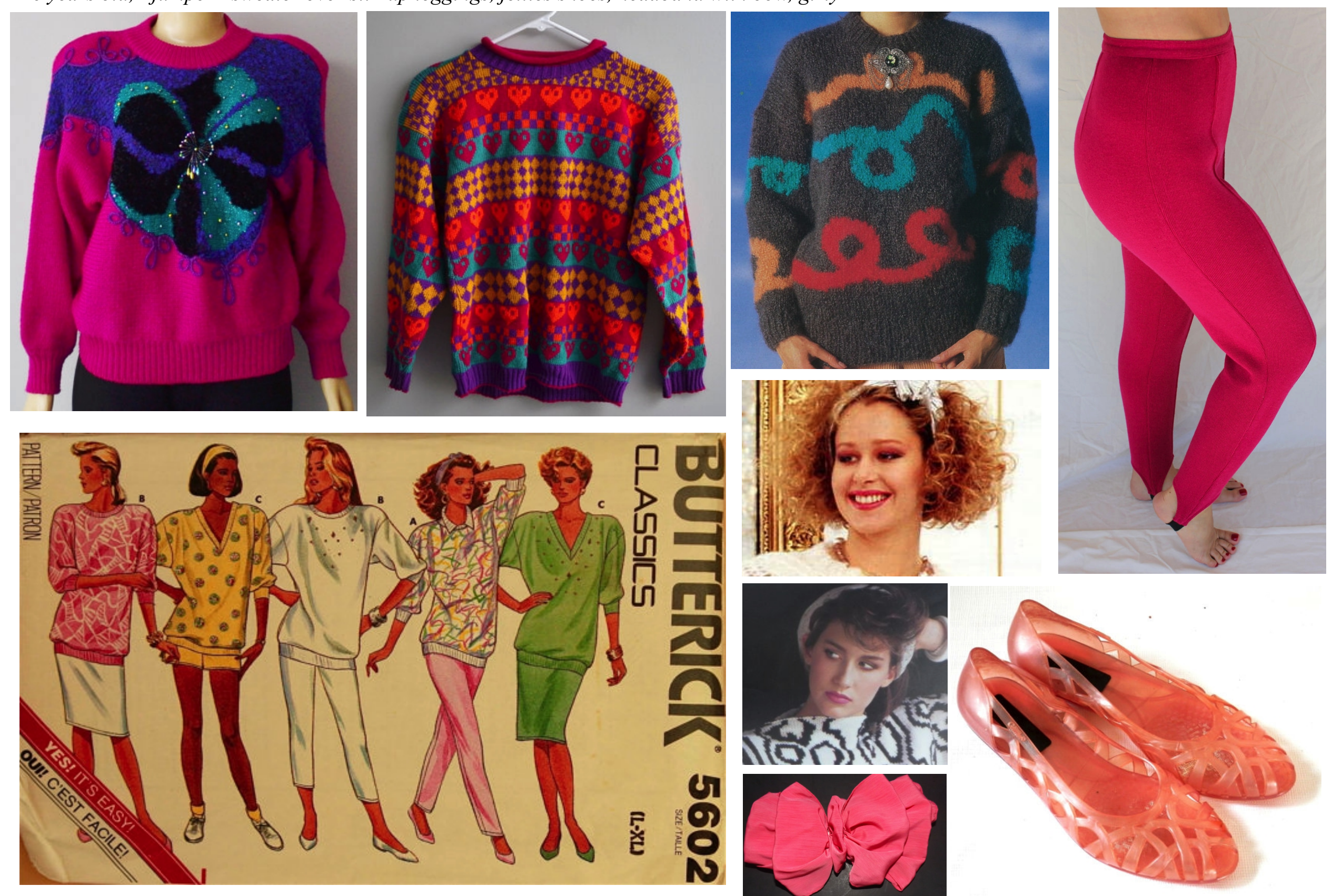


\section{Warden Hartman}

Based on Ross Maggio, business casual, also in dark colors, maybe 2-piece business suit
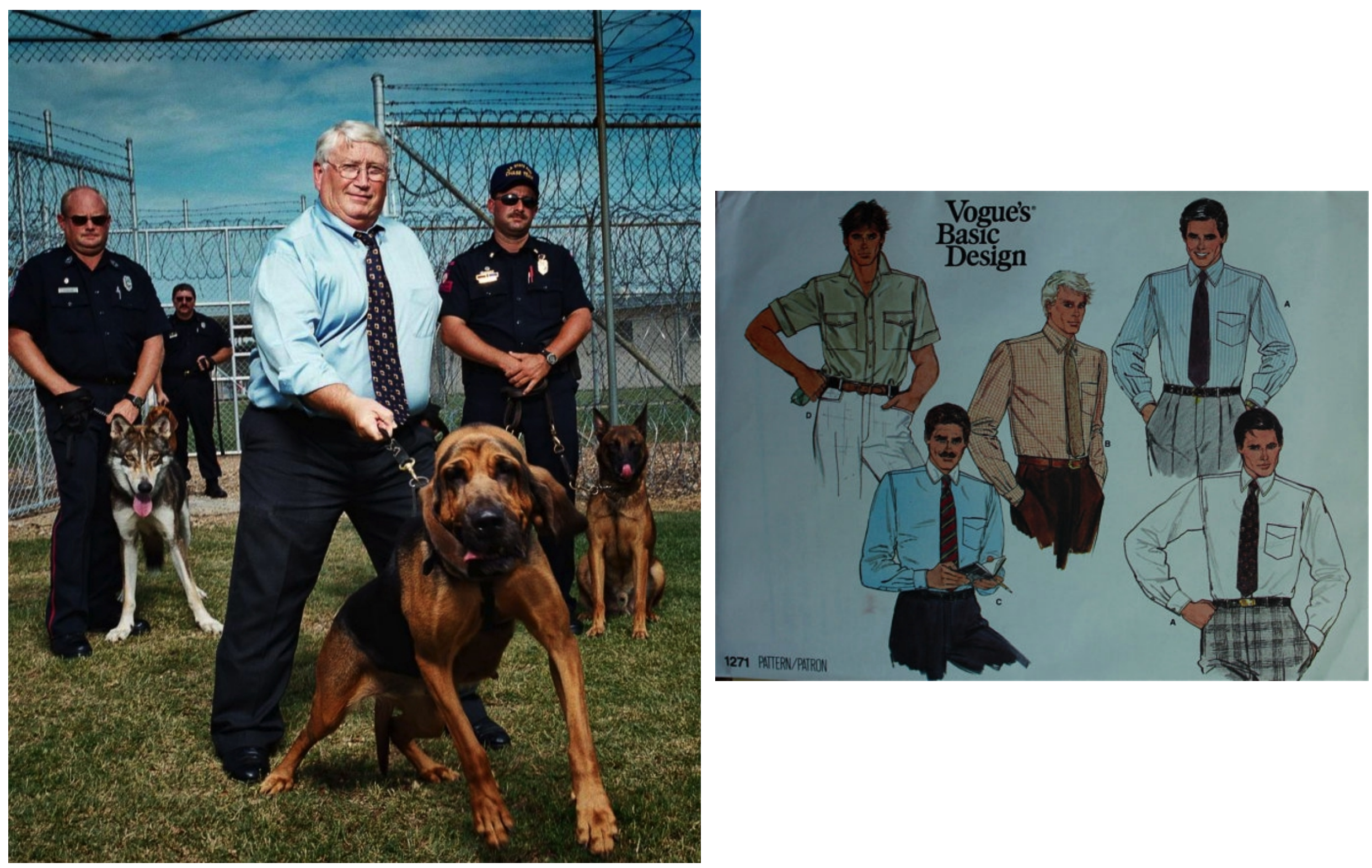

Warden Burl Cain of LSP 
Sergeant. Beliveau \& Guards

Same uniformg for sergeant but add proper insignia: 3 stripes for collar pins and shoulder patch

Guard Trapp, 2 male guards and one female - navy shirts with insignia/badges, navy pants
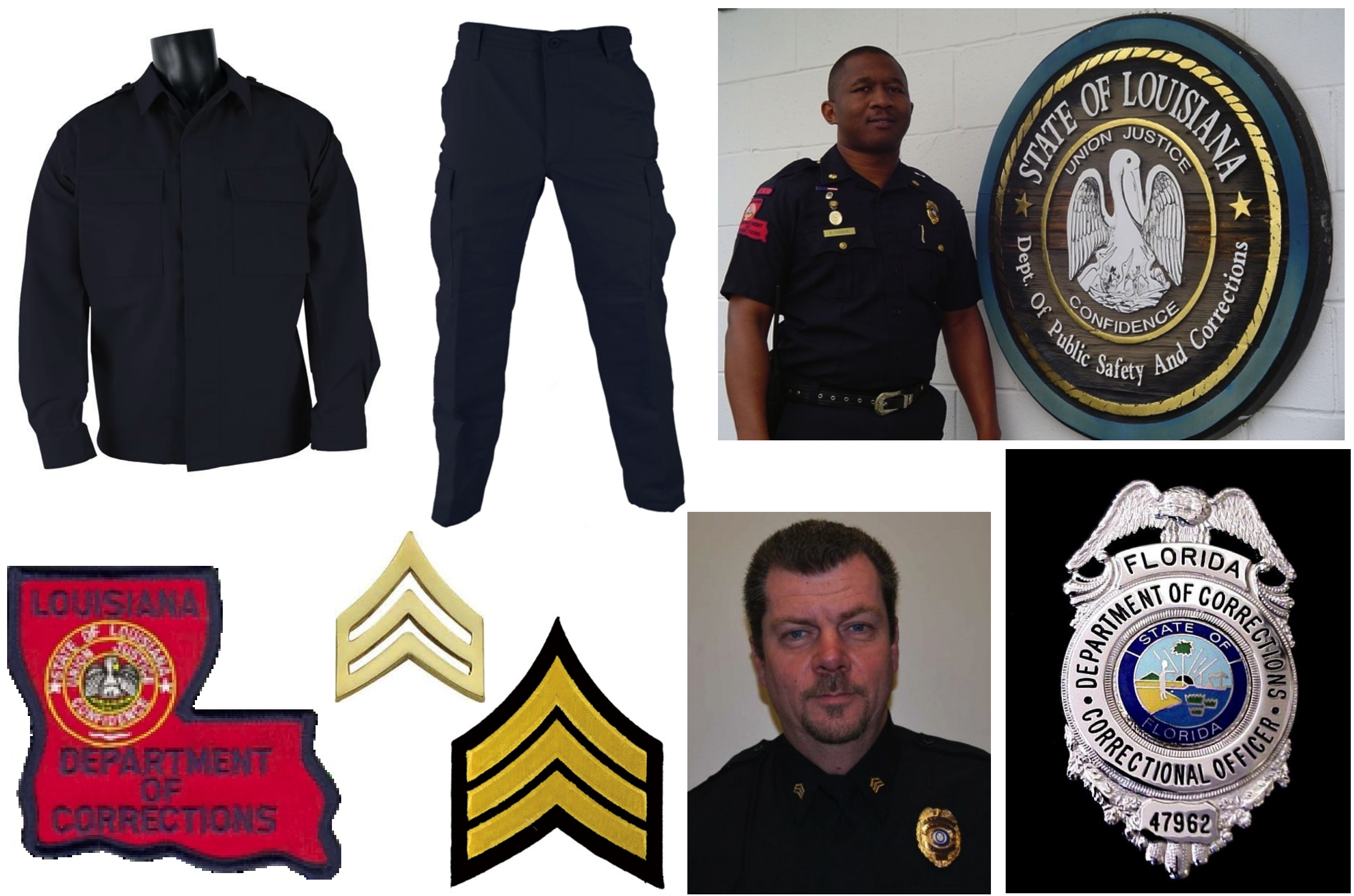

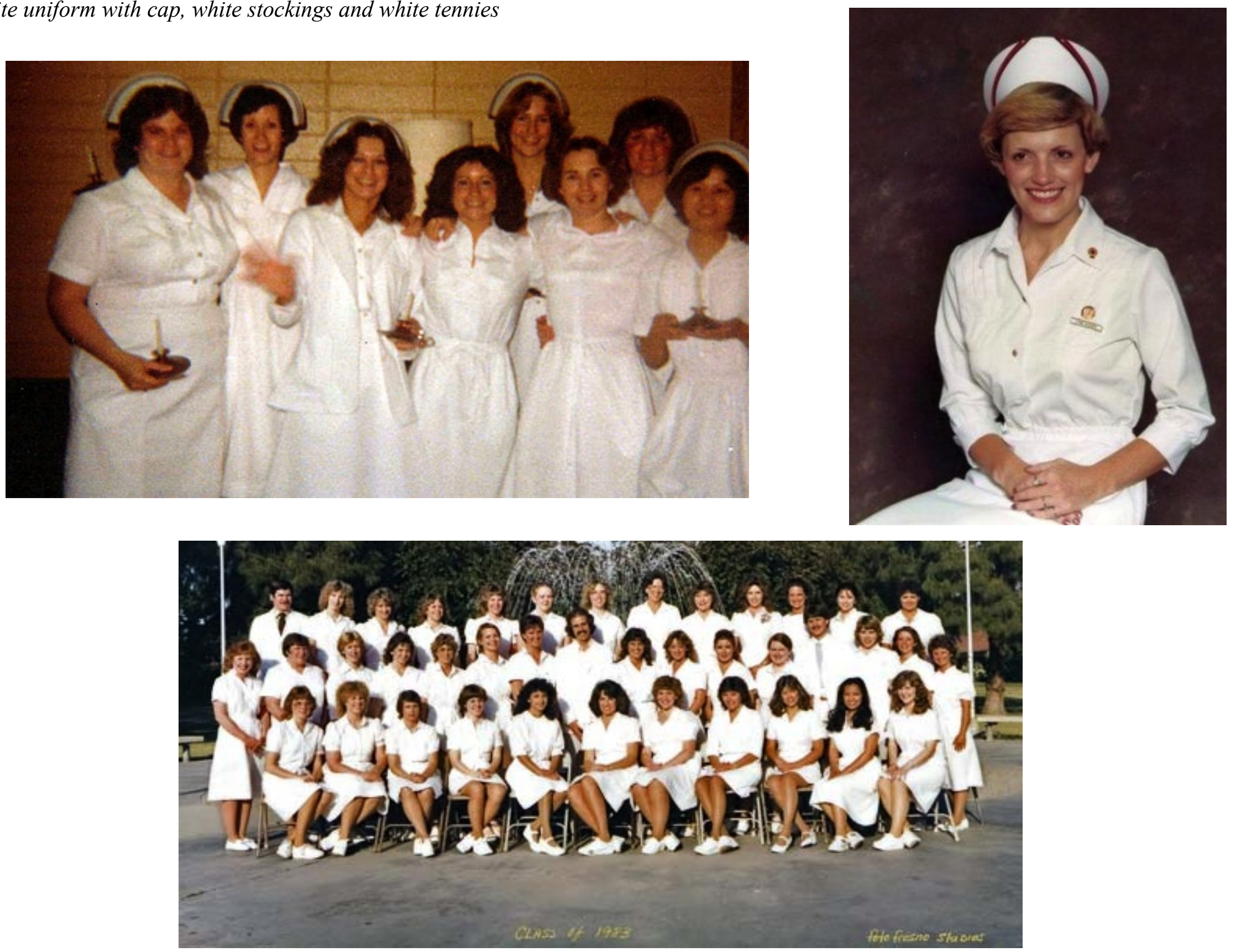
Men of victim's support group (3)

Mix of casual wear: button-down shirts, jeans, slacks, vests, windbreakers, etc.
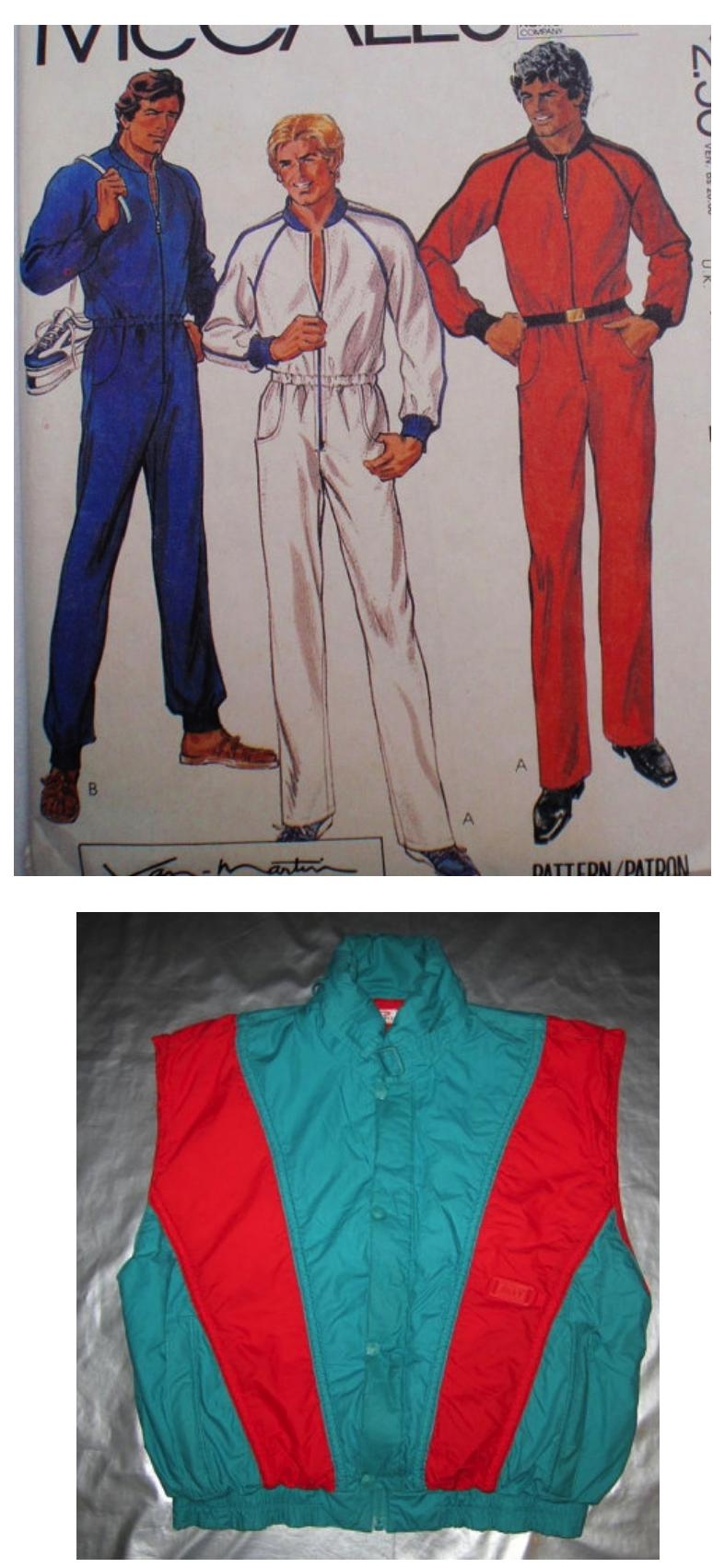
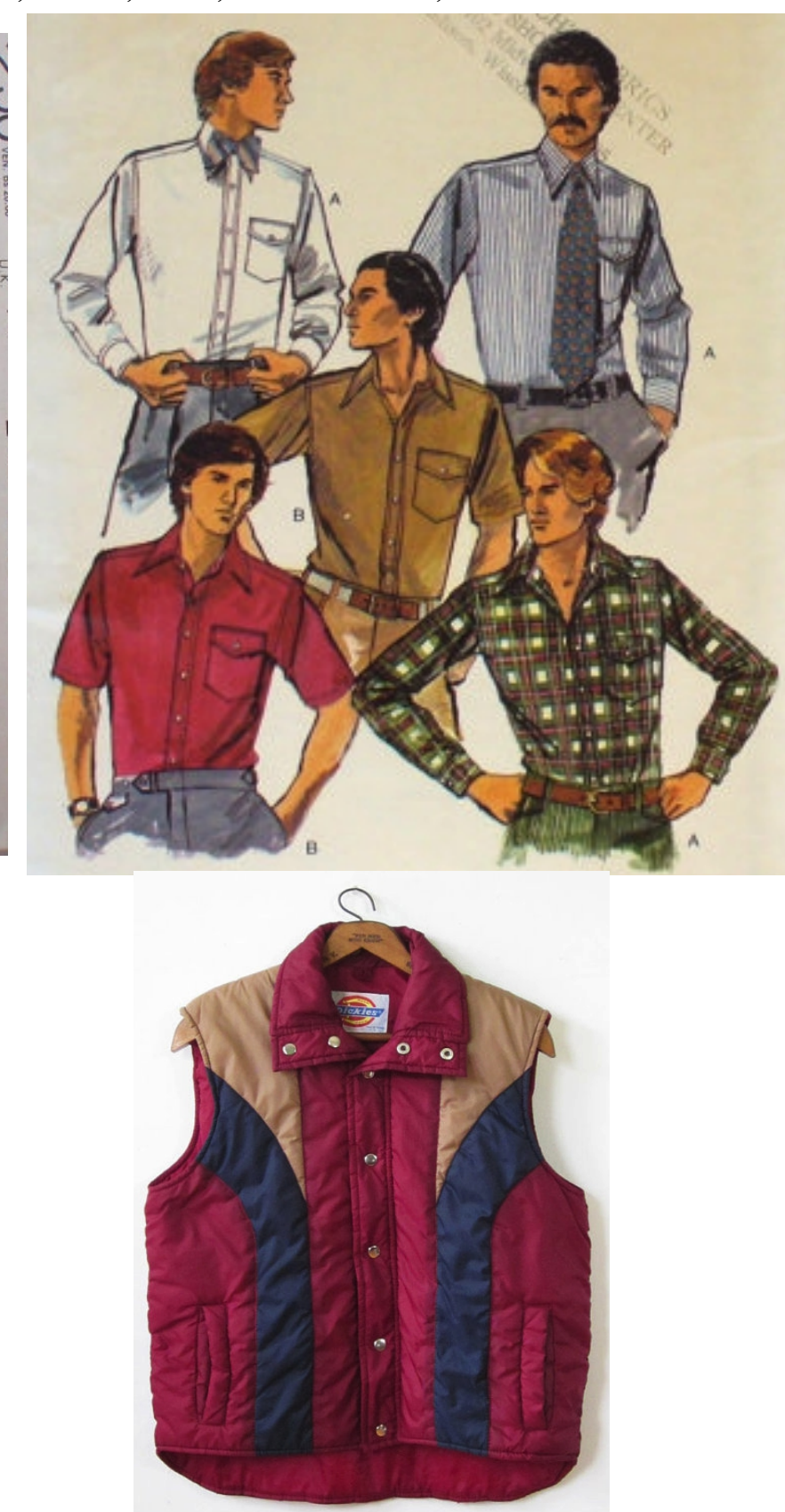

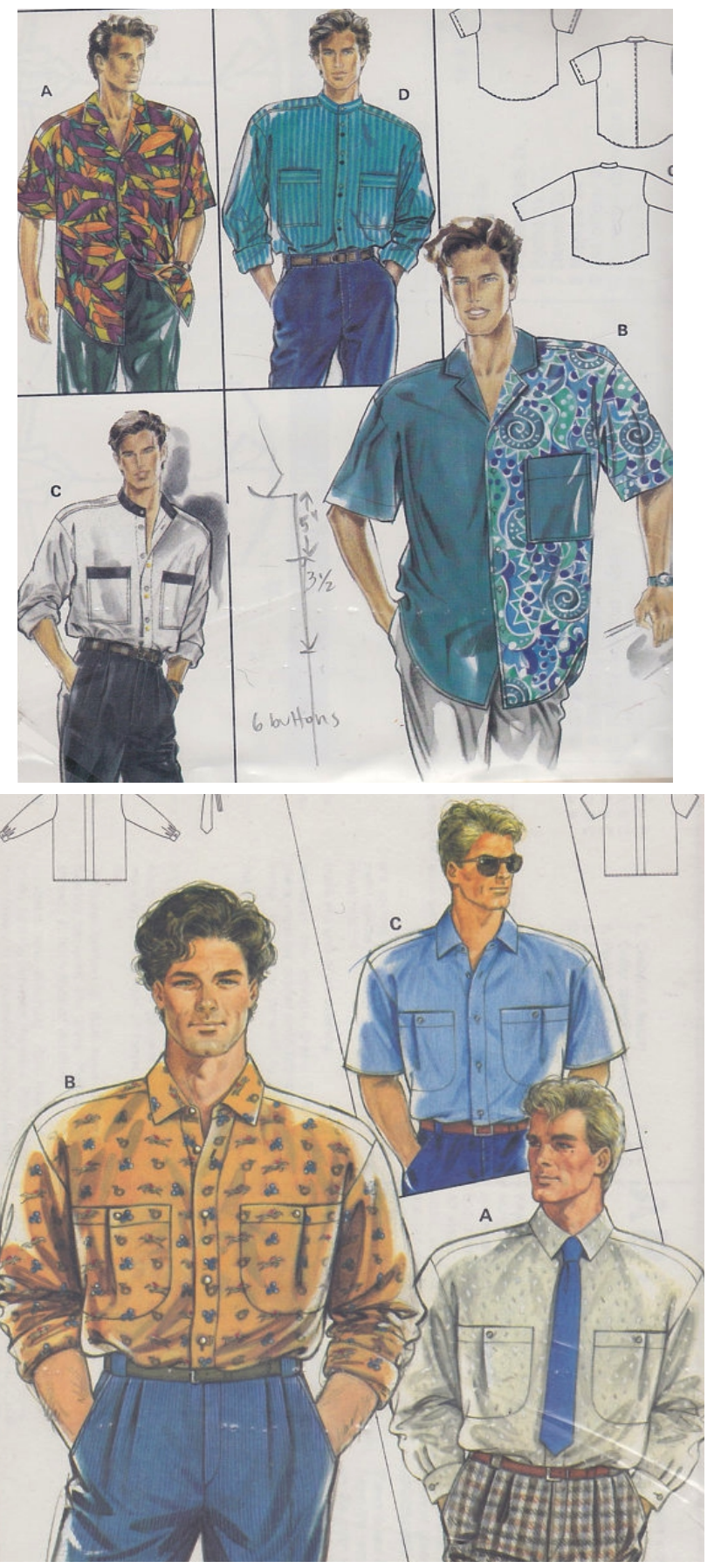

Senior Honors Thesis - Siow 
Women of victim's support group (3)

Big coats over blouses and slacks or skirts, more color/patterns in clothing and big jewelry
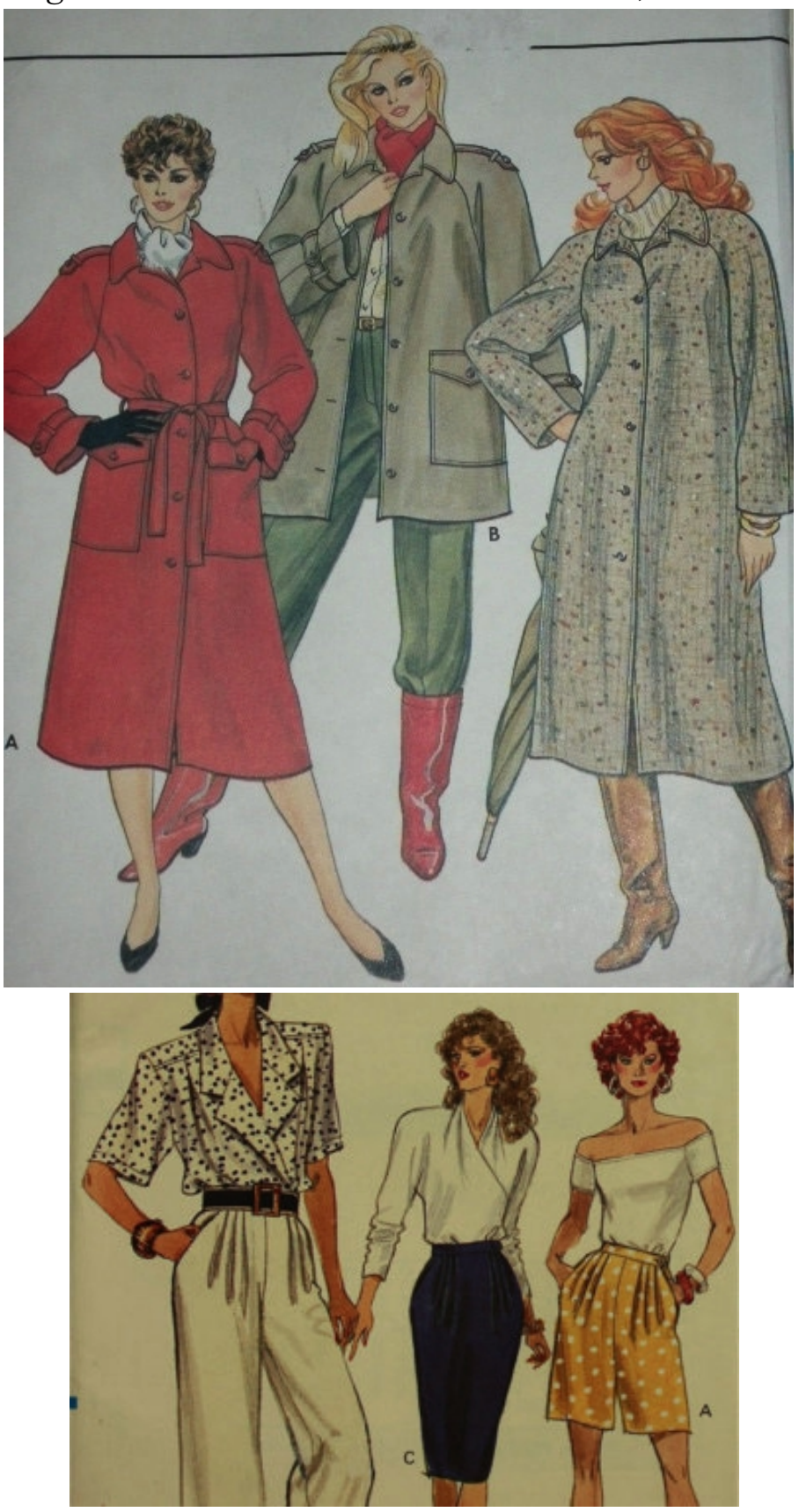
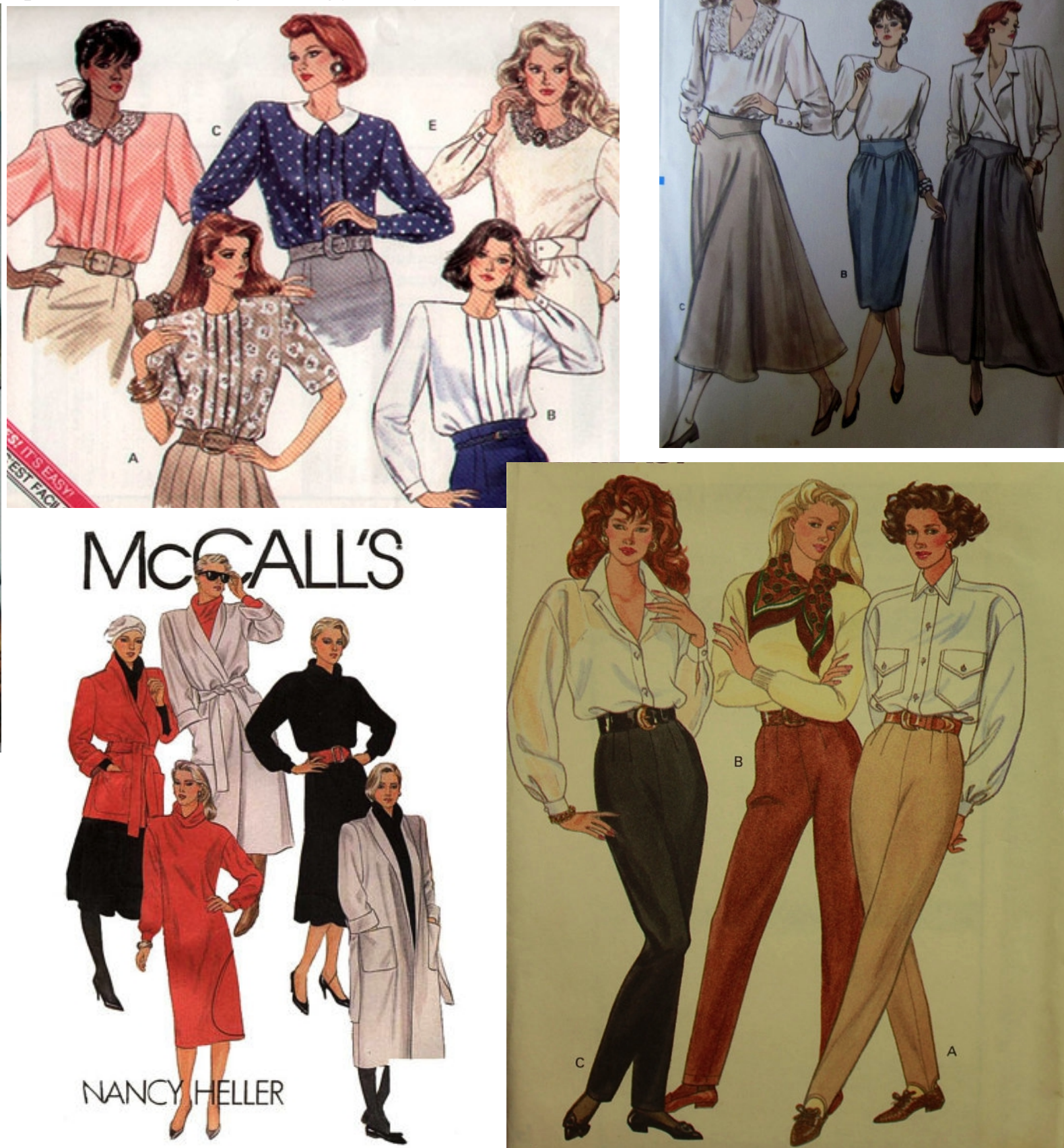
Reporters (4)

Tucked in dress shirts, ties, belt, slacks if men; tucked in blouse and slacks if women; some with glasses, could add scarves, sportscoat or vest
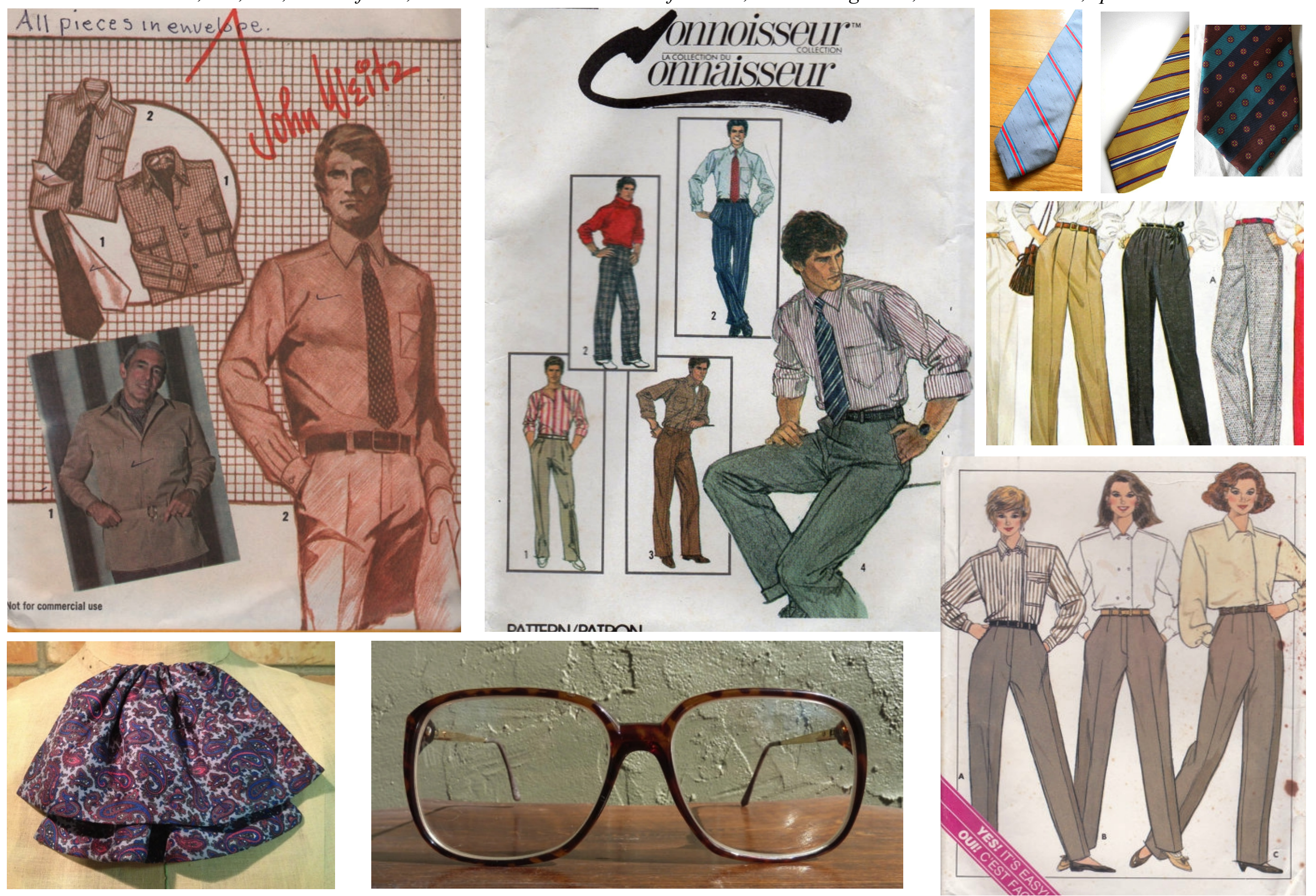


\section{Costume SKetches}

These are the rough pencil sketches of various characters.

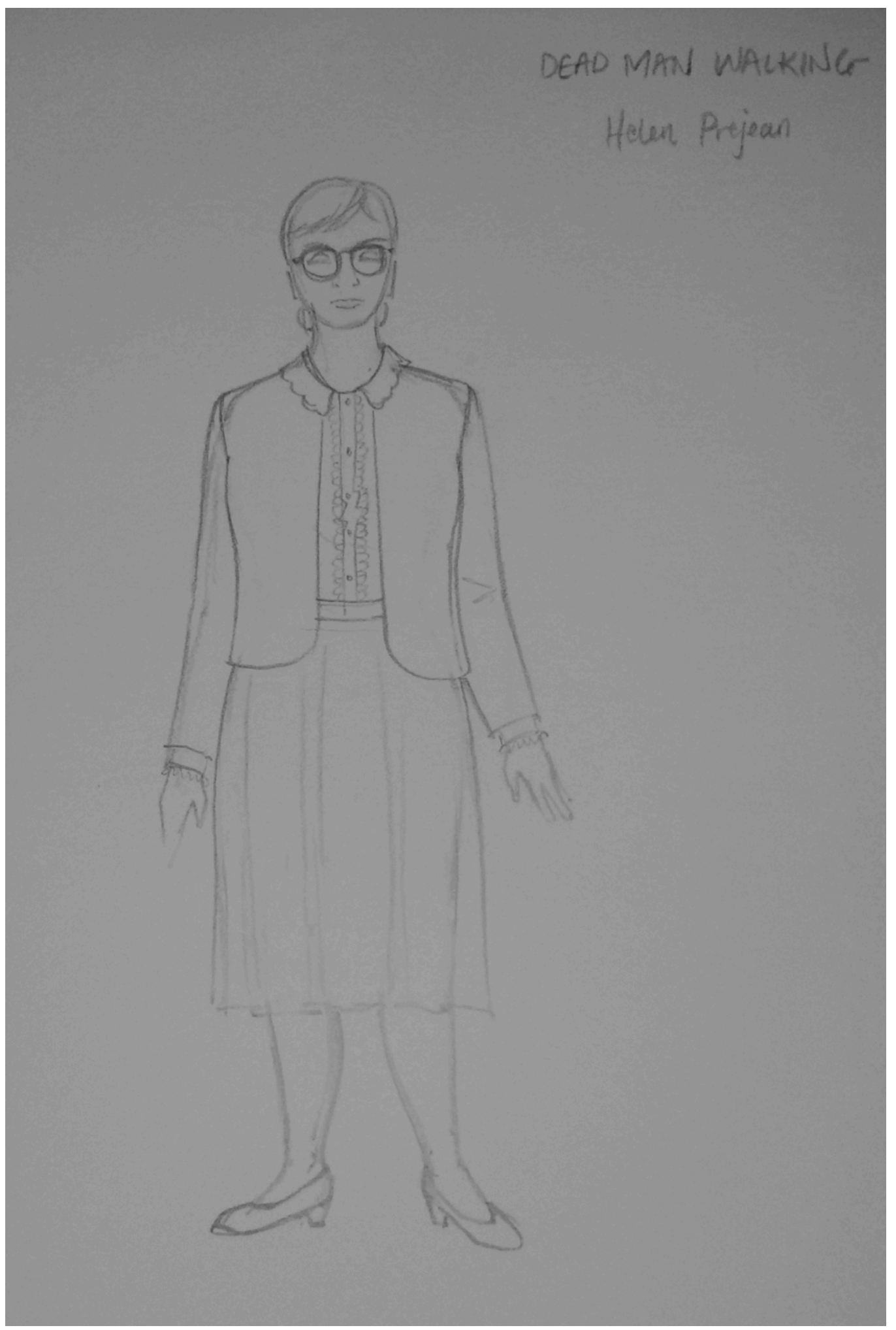




\section{DEAO MATS WALKINE}

Wstrer Delacrois

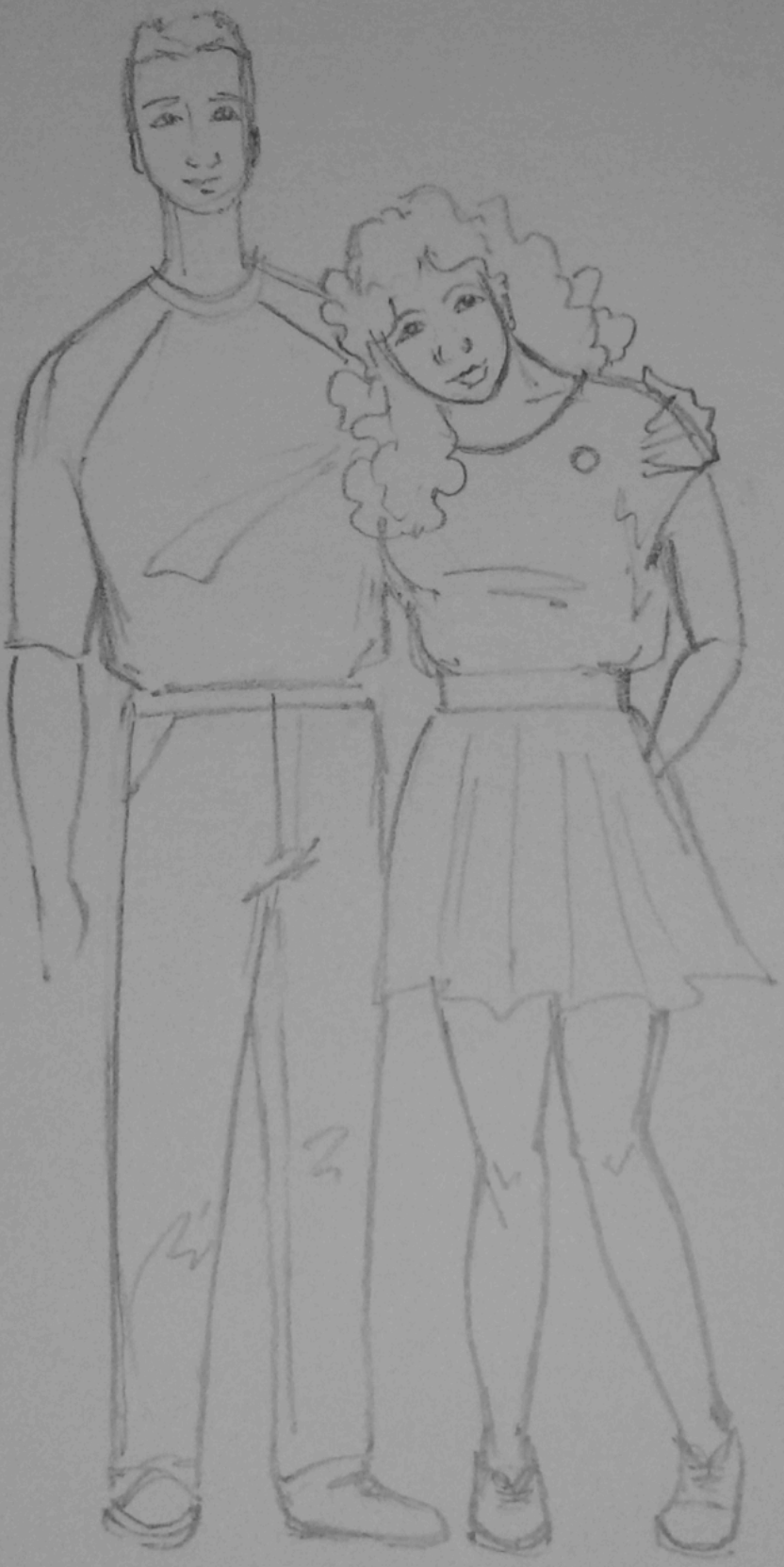


DEAD MAN WALKINS Mathew Poncelet
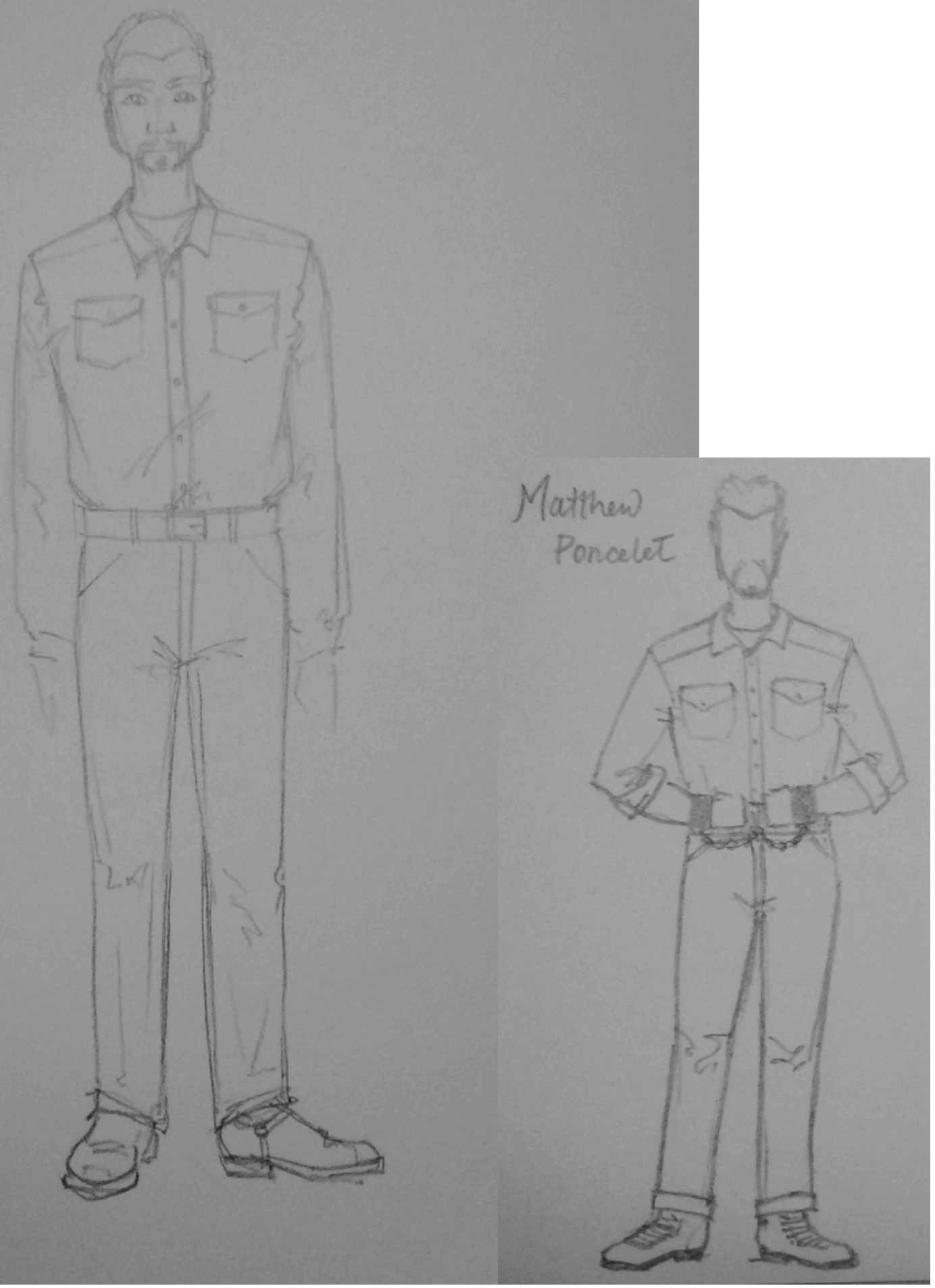

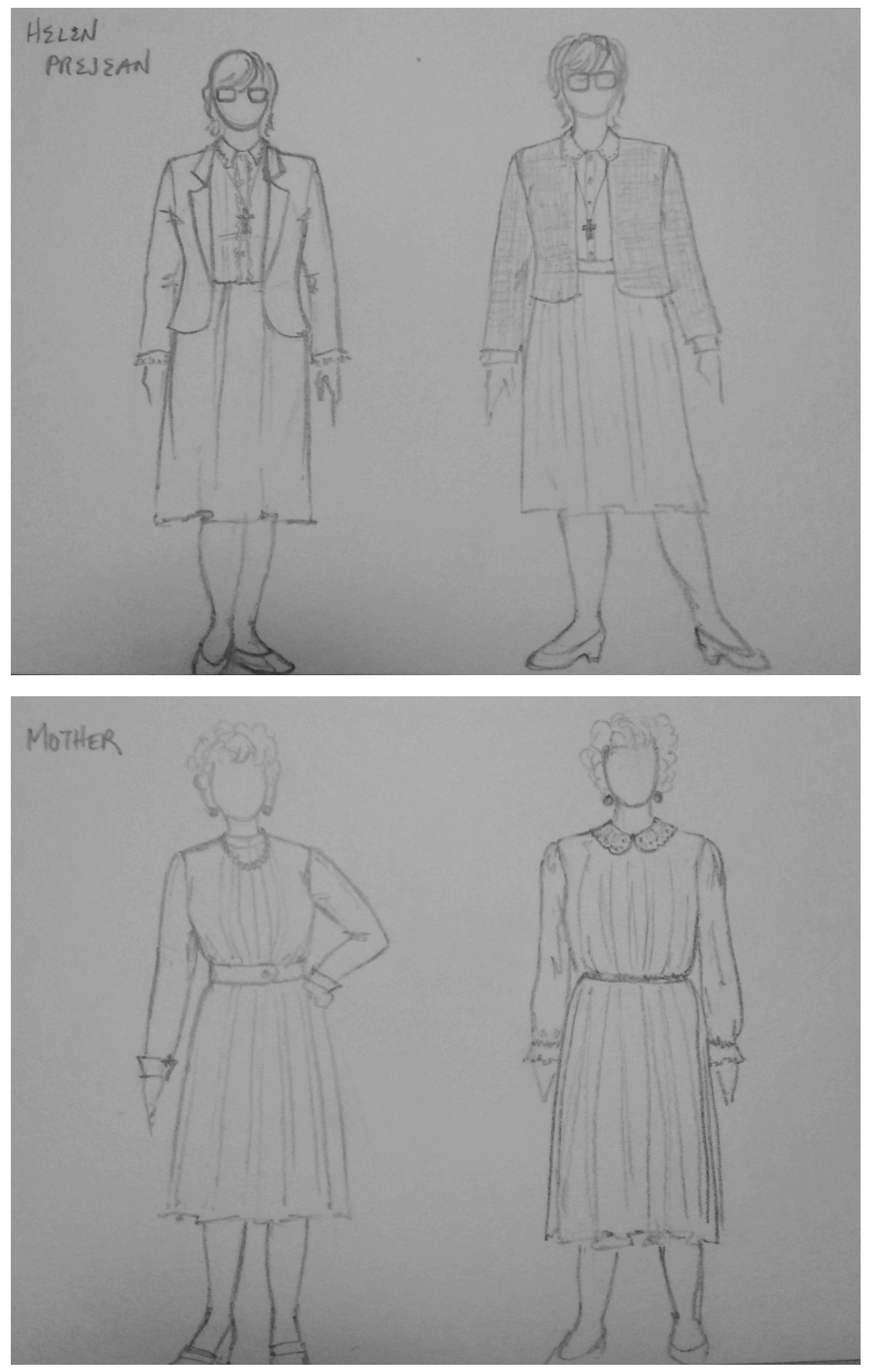

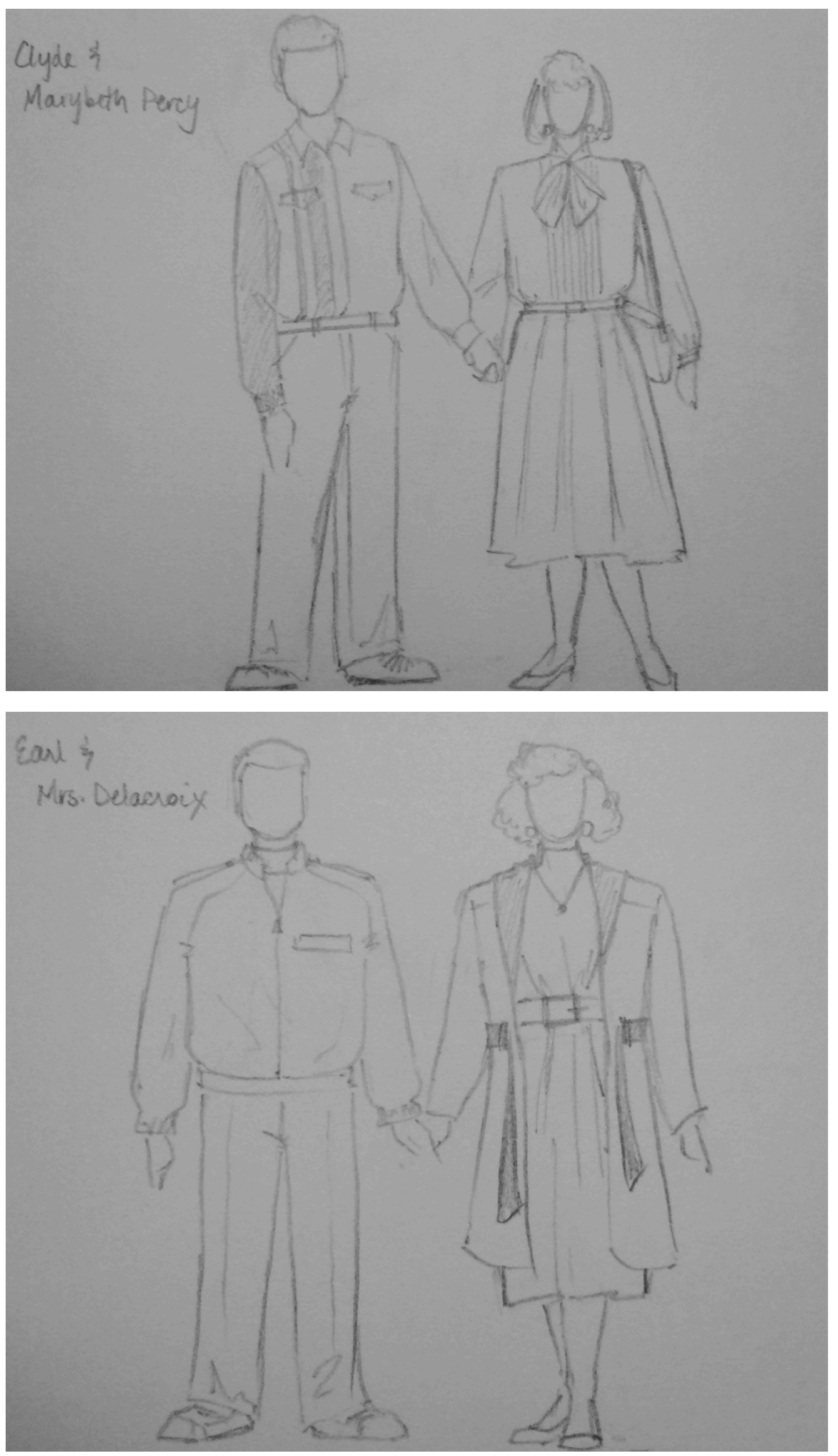

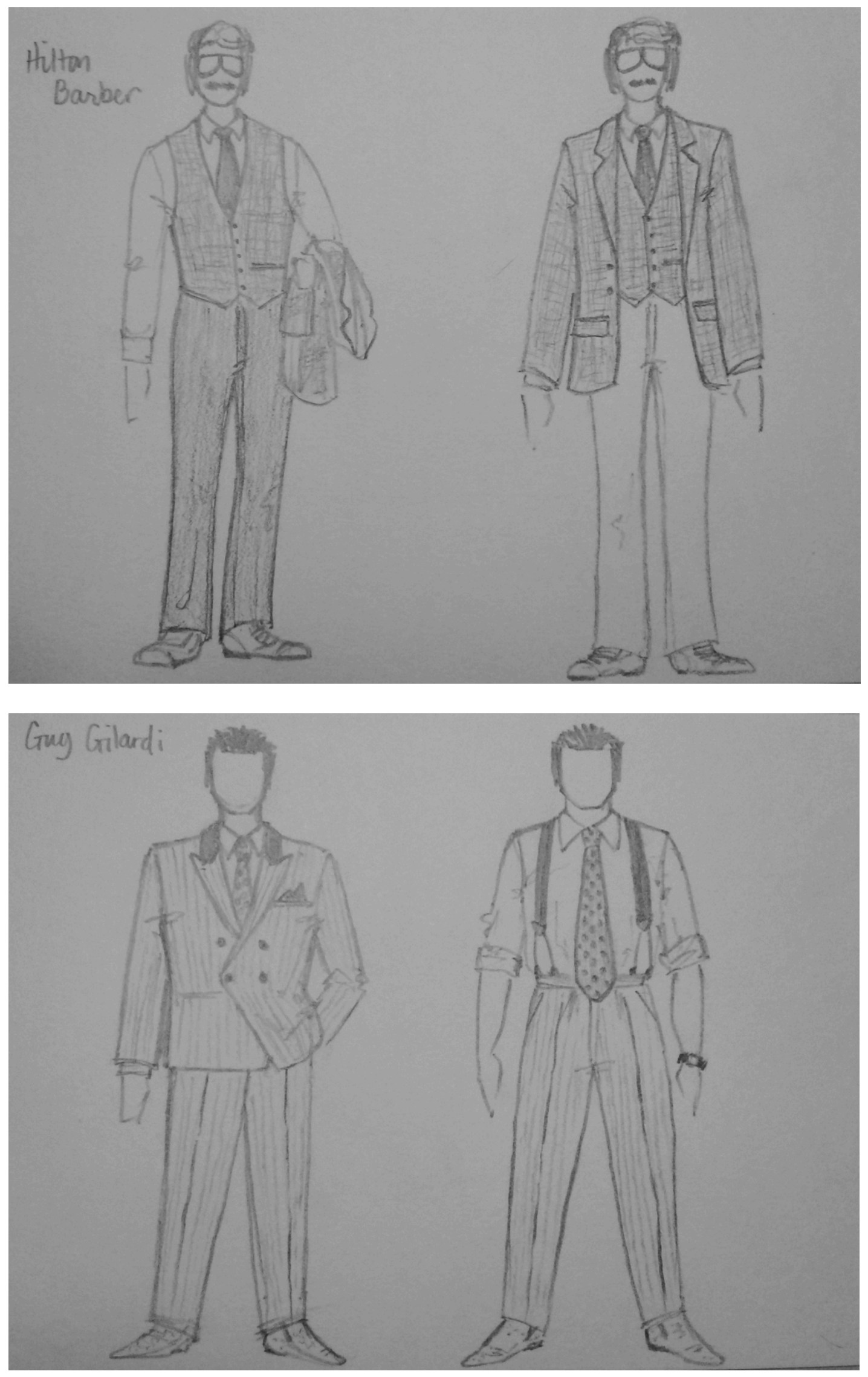

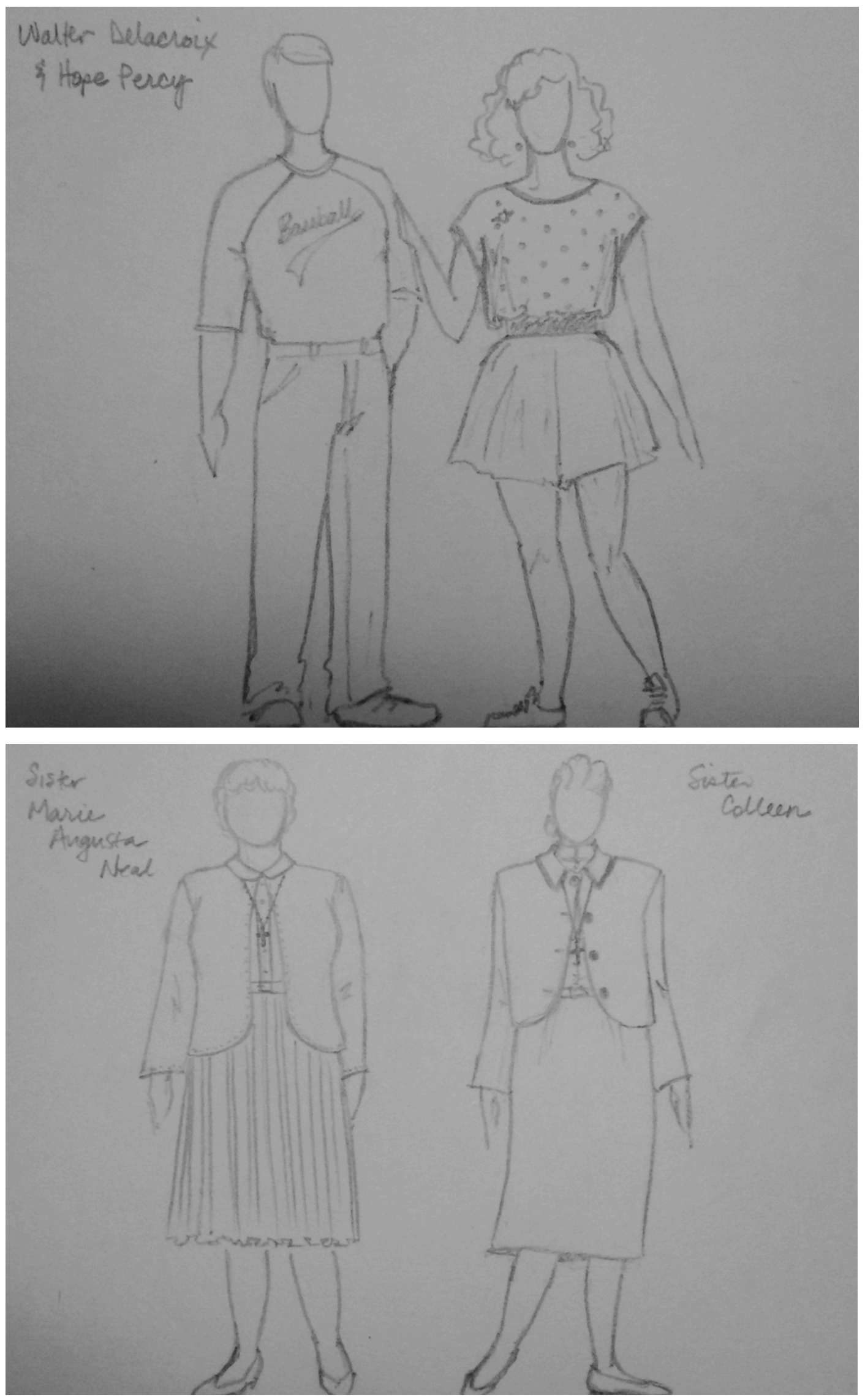


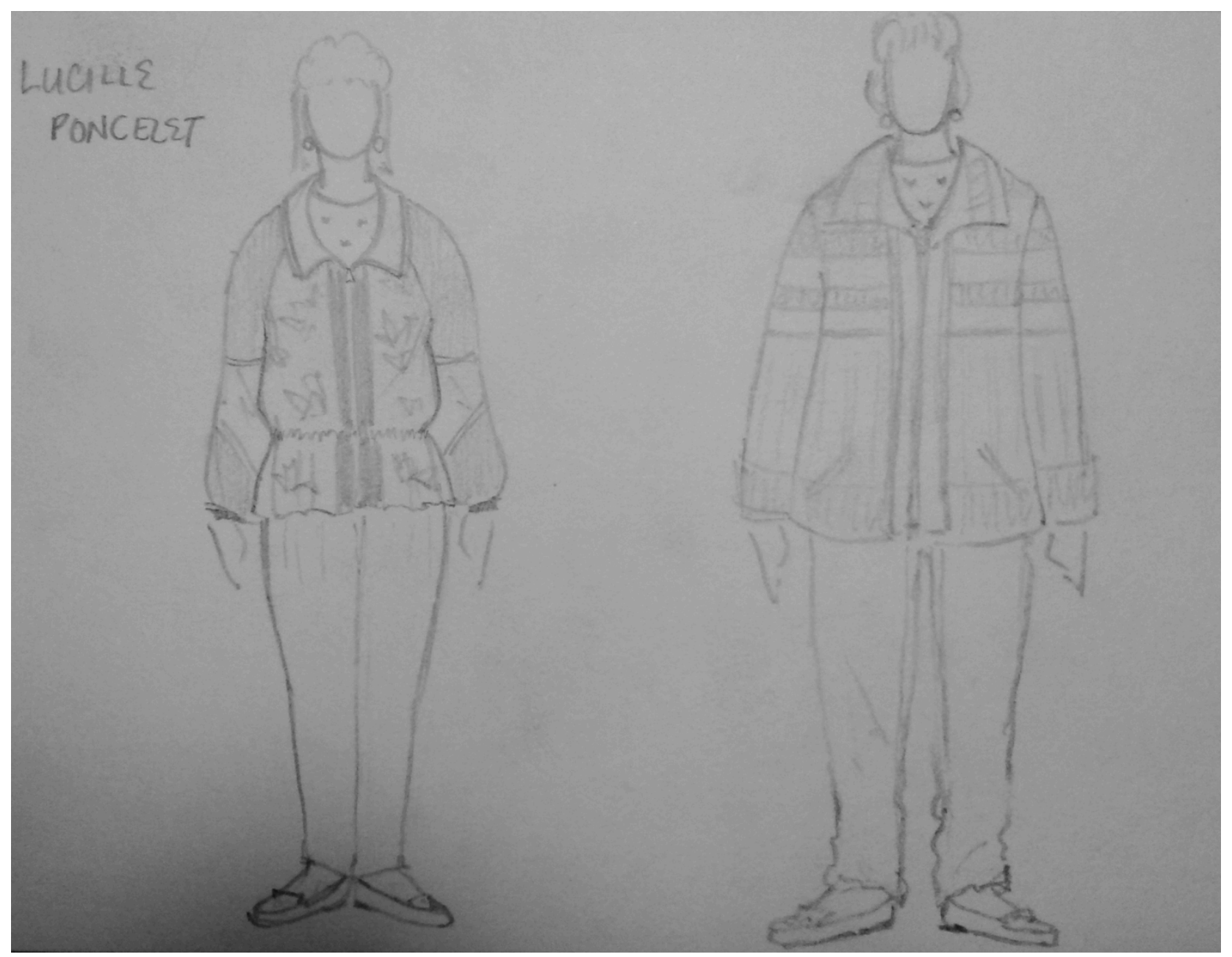




\section{FINAL RENDERINGS}

The final, full-color renderings of the costumes for selected characters. These renderings were done after the production was over.

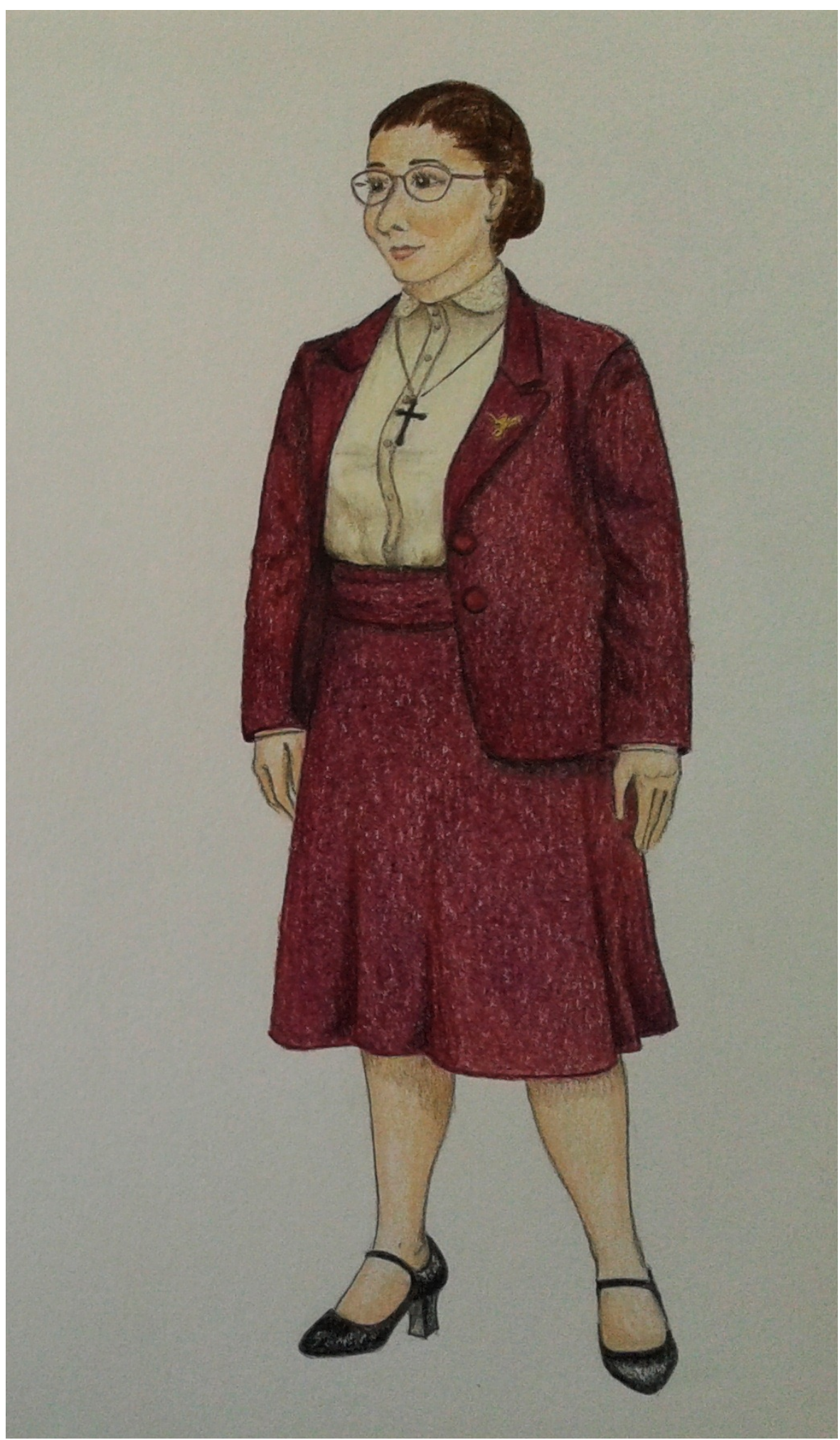

Sister Helen Prejean 


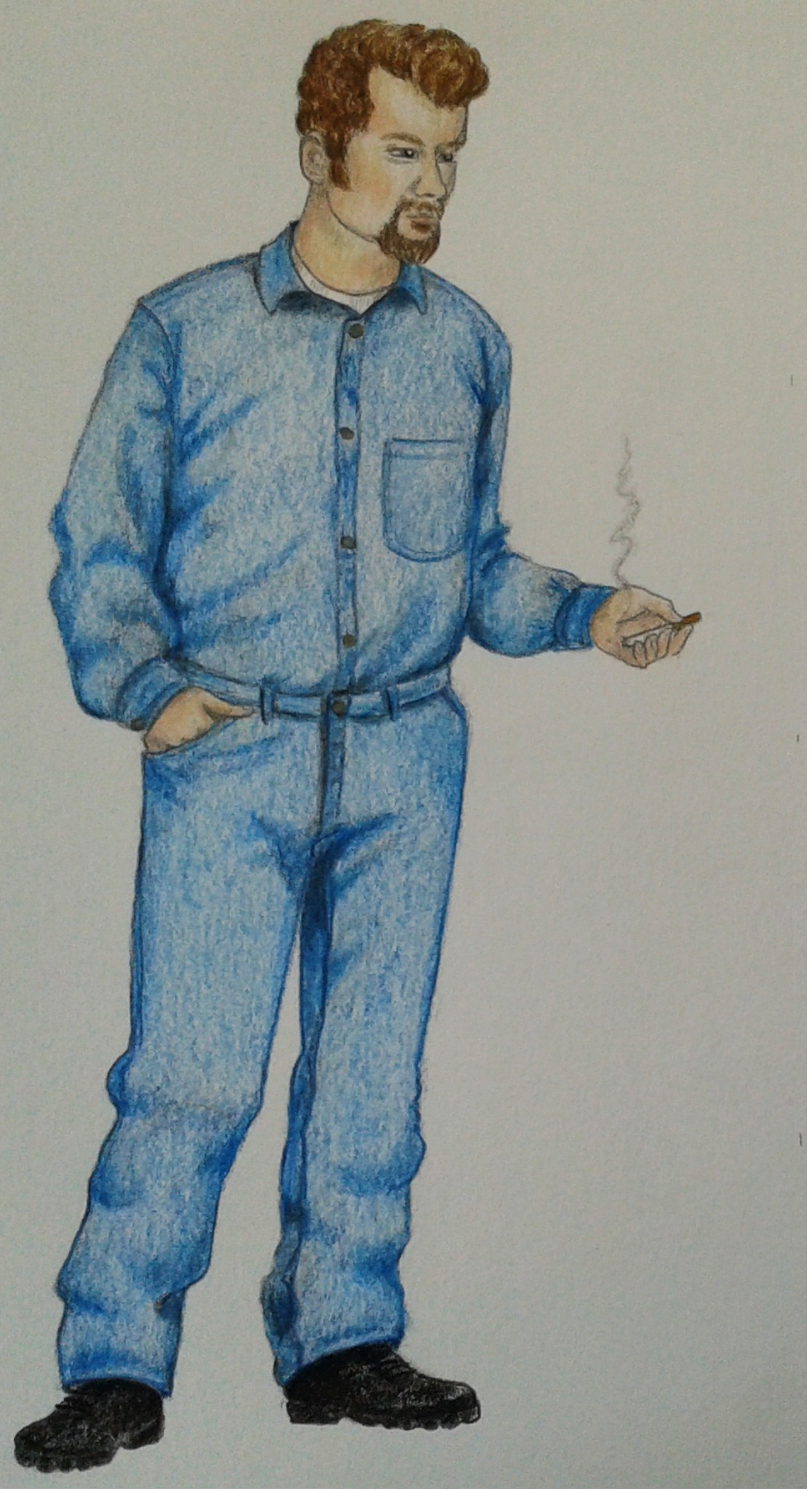

Matthew Poncelet 


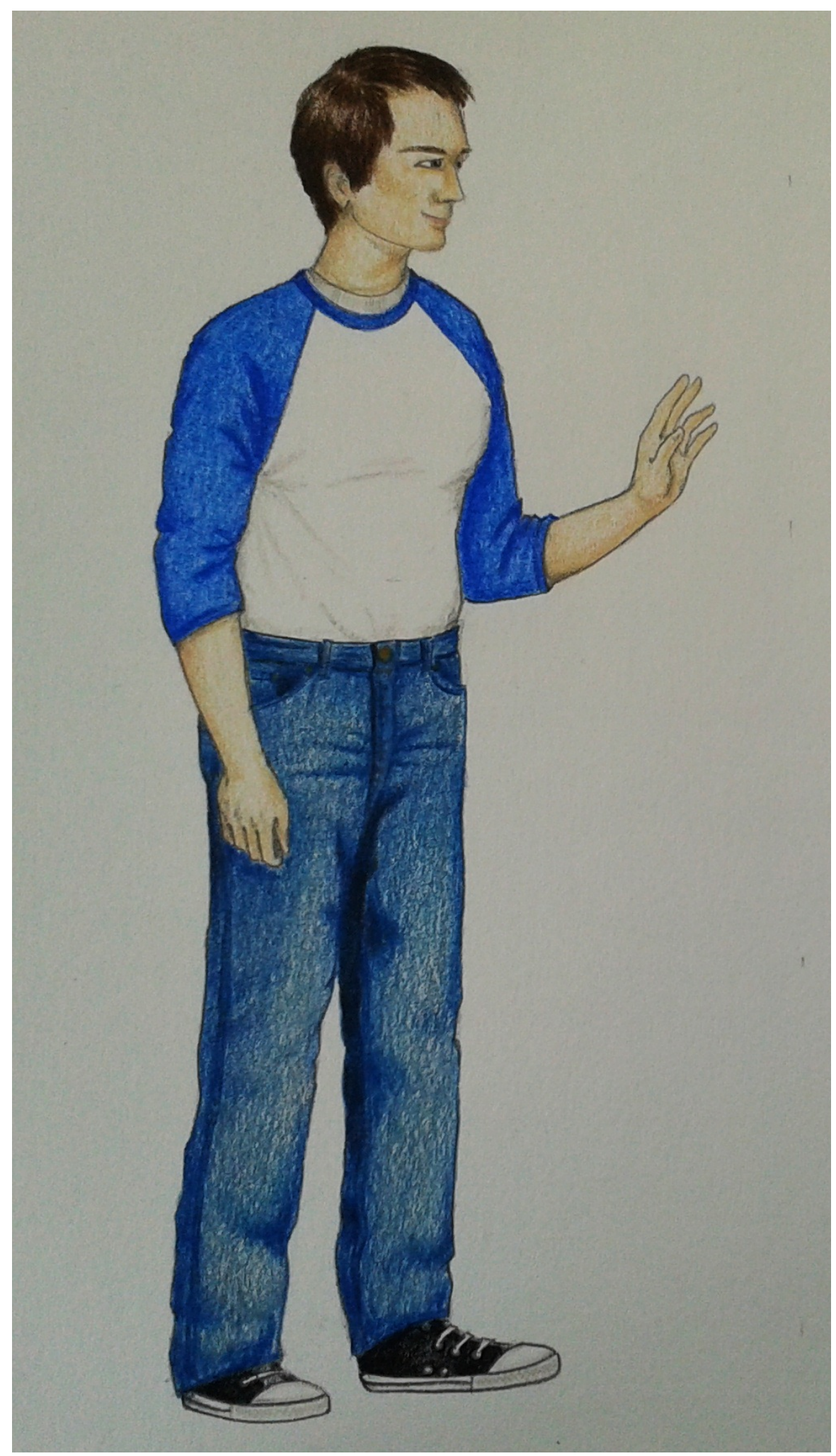

Walter Delacroix 


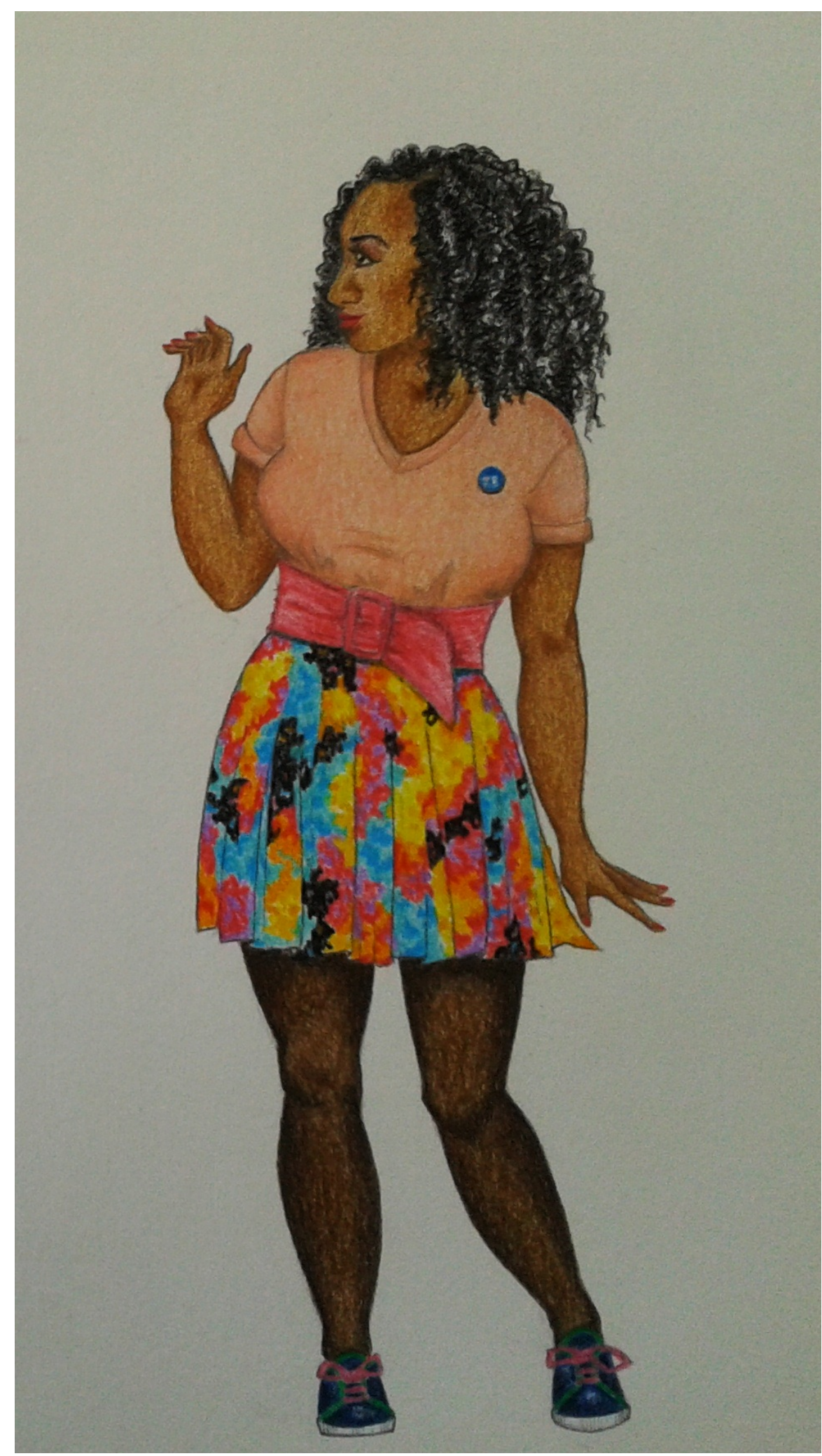

Hope Percy 


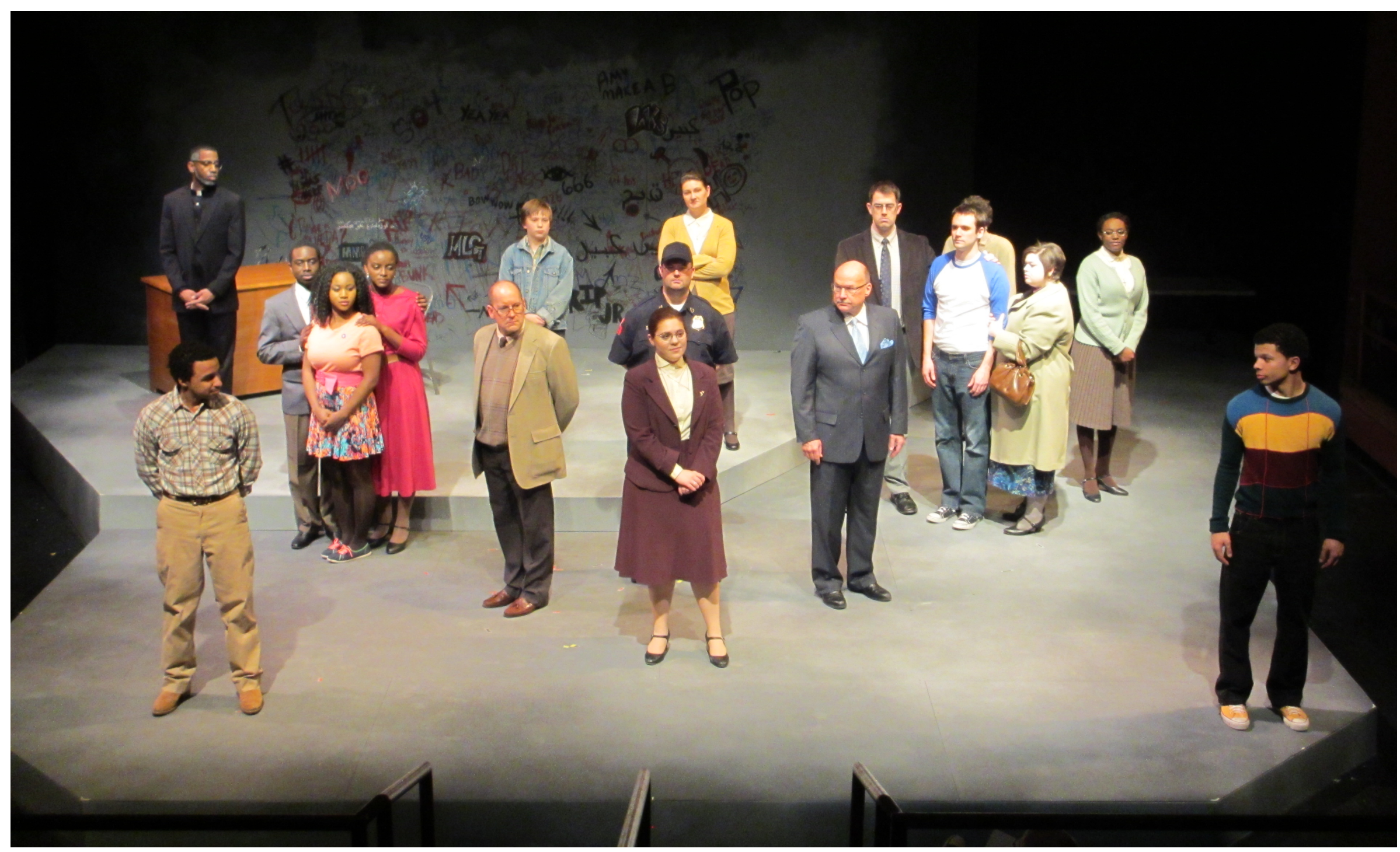

Figure 1. Opening Tableau-Act I, scene 1: all actors except for David Galloway. 


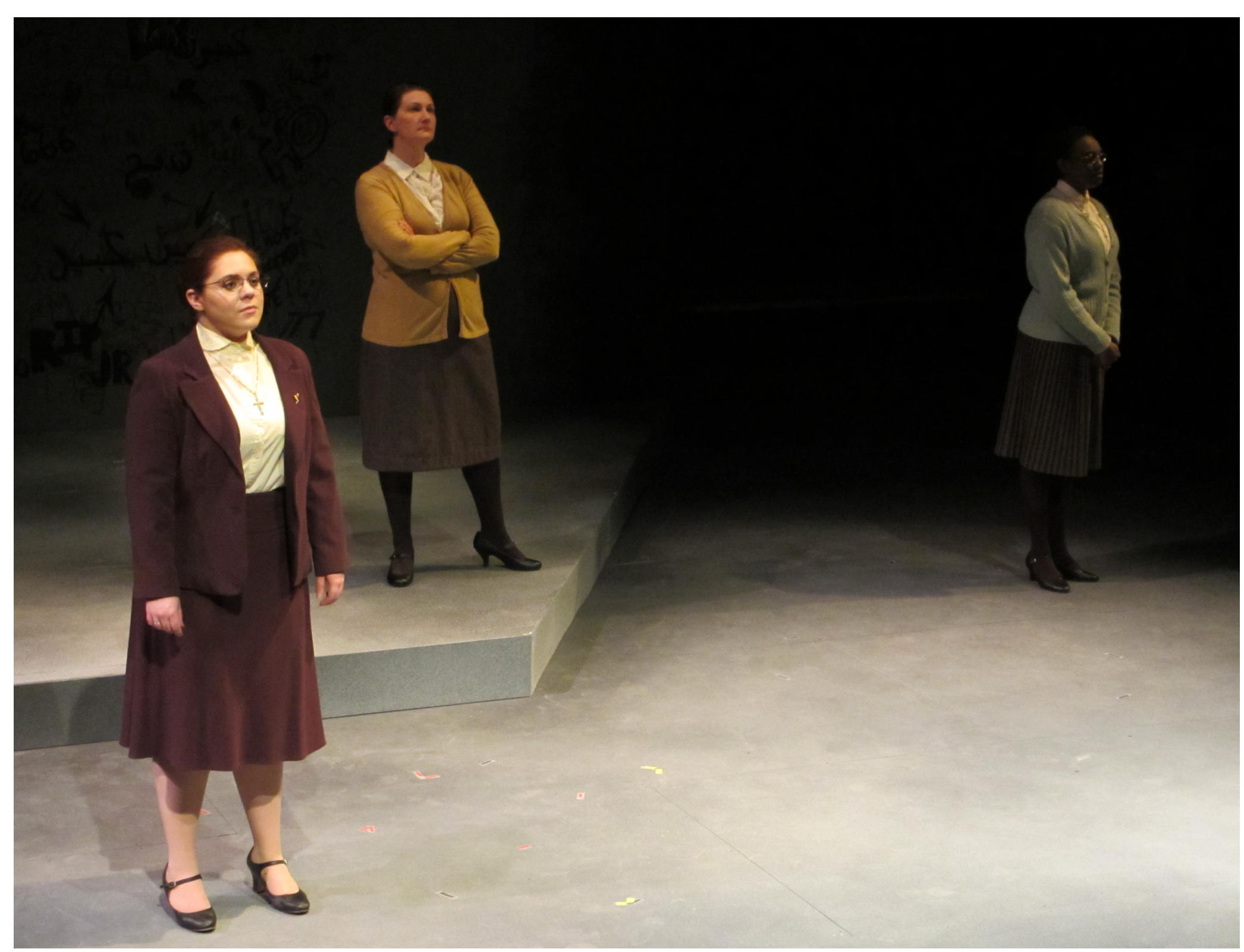

Figure 2. The Sisters of St. Joseph - Act I, scene 2: (from left) Sister Helen, Sister Marie Augusta Neal, Sister Colleen. 


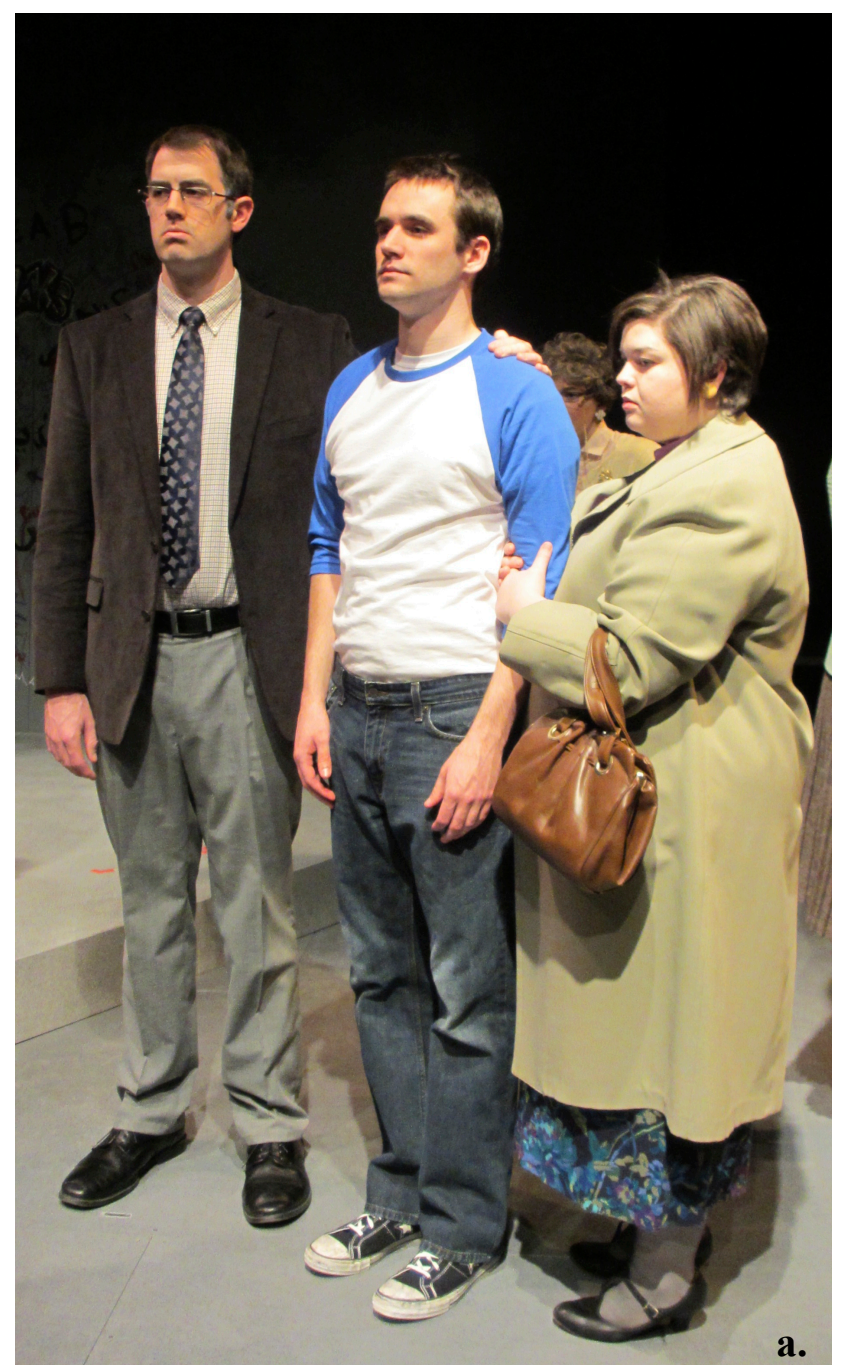

a.

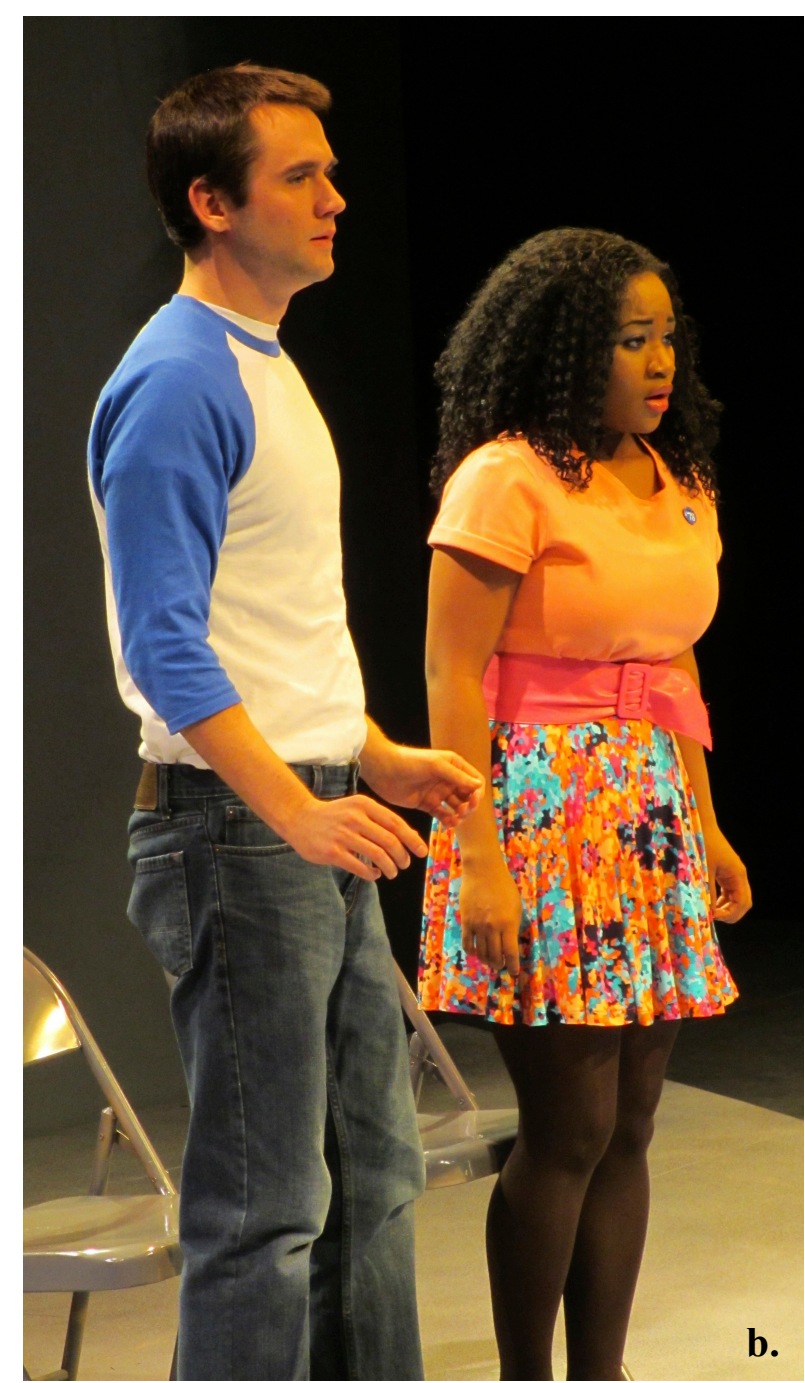

b.

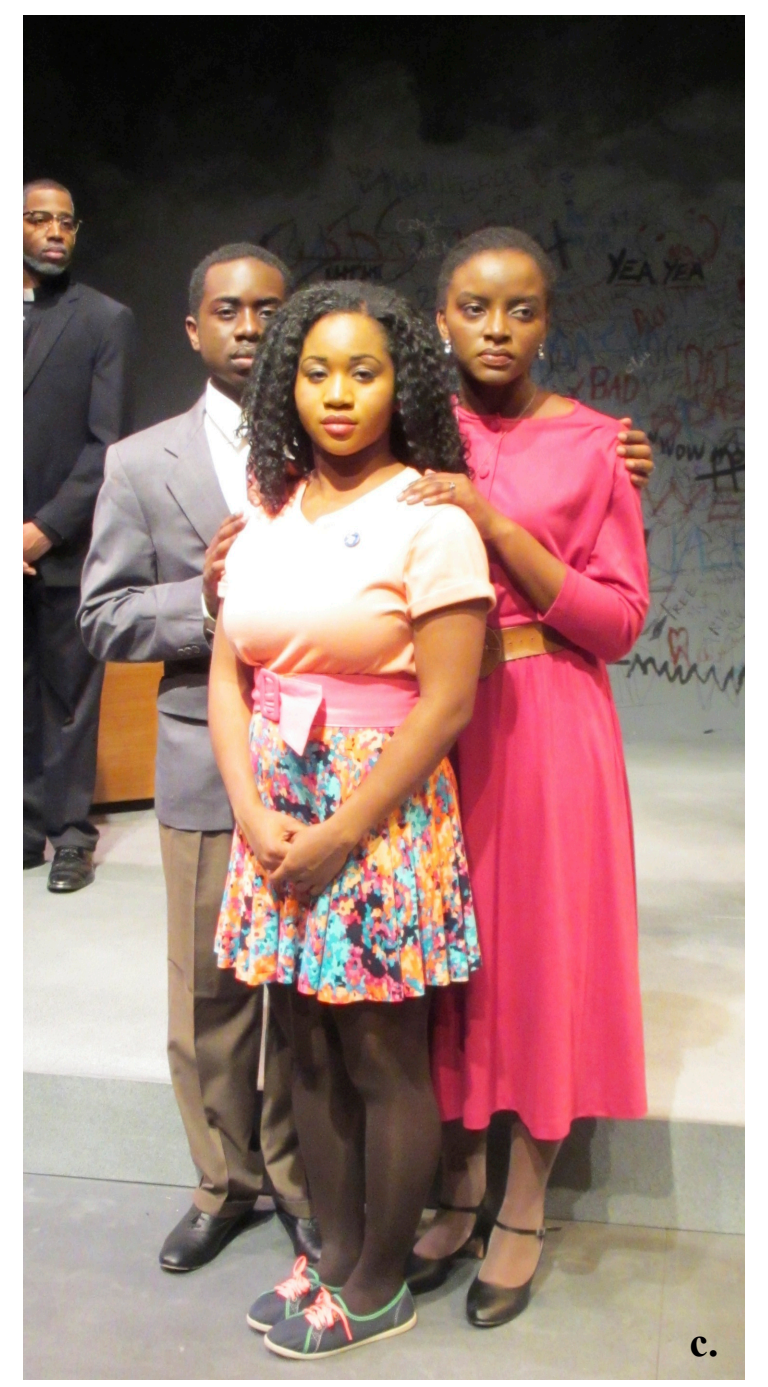

Figure 3a. The Delacroix Family - Act I, scene 1: (from left) Earl, Walter, and Mrs. Delacroix Figure 3b. The Young Couple - Act II, scene 29: (from left) Walter Delacroix and Hope Percy Figure 3c. The Percy Family - Act I, scene 1: (from left) Clyde, Hope, and Marybeth Percy 

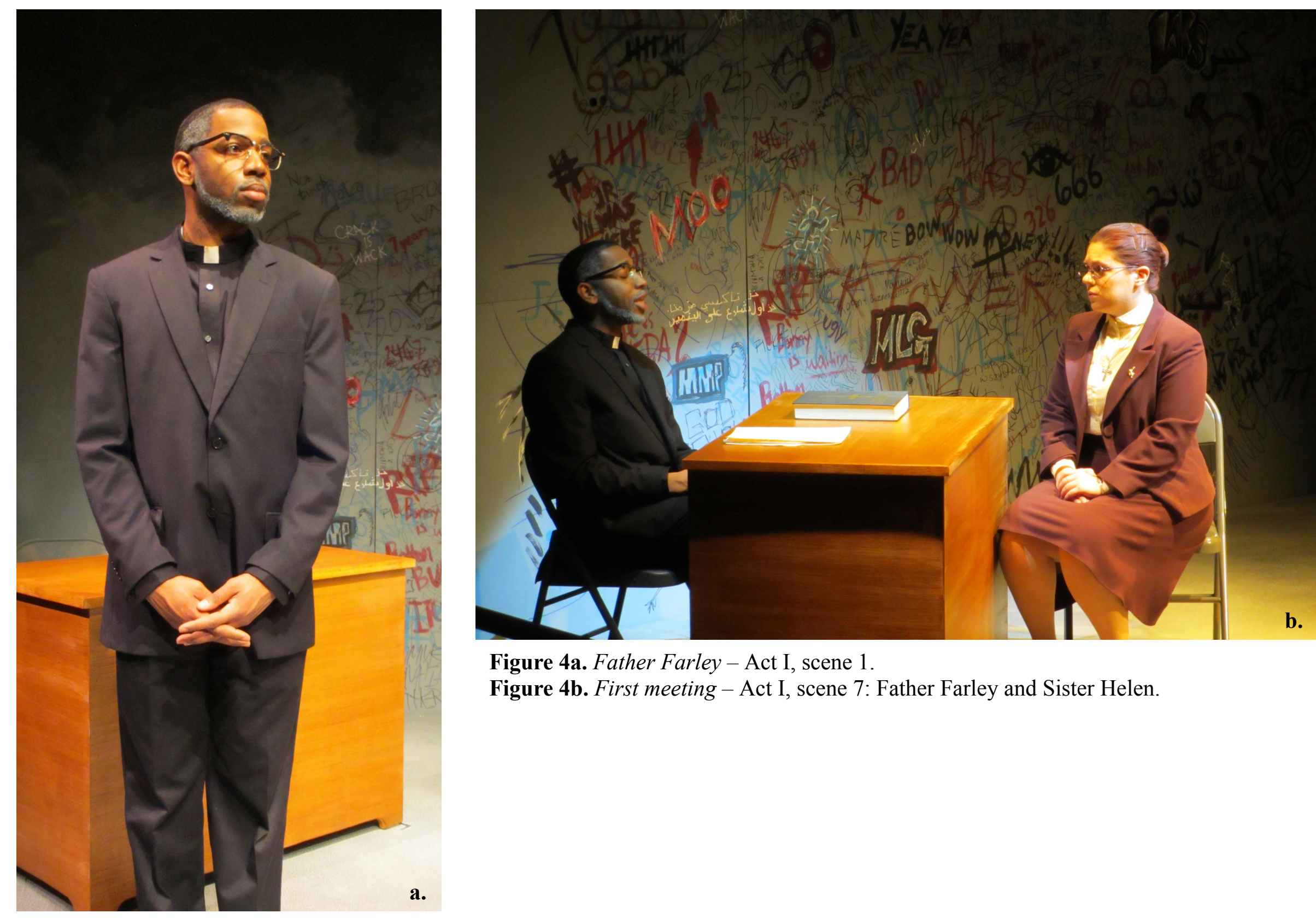

Figure 4a. Father Farley - Act I, scene 1.

Figure 4b. First meeting - Act I, scene 7: Father Farley and Sister Helen. 

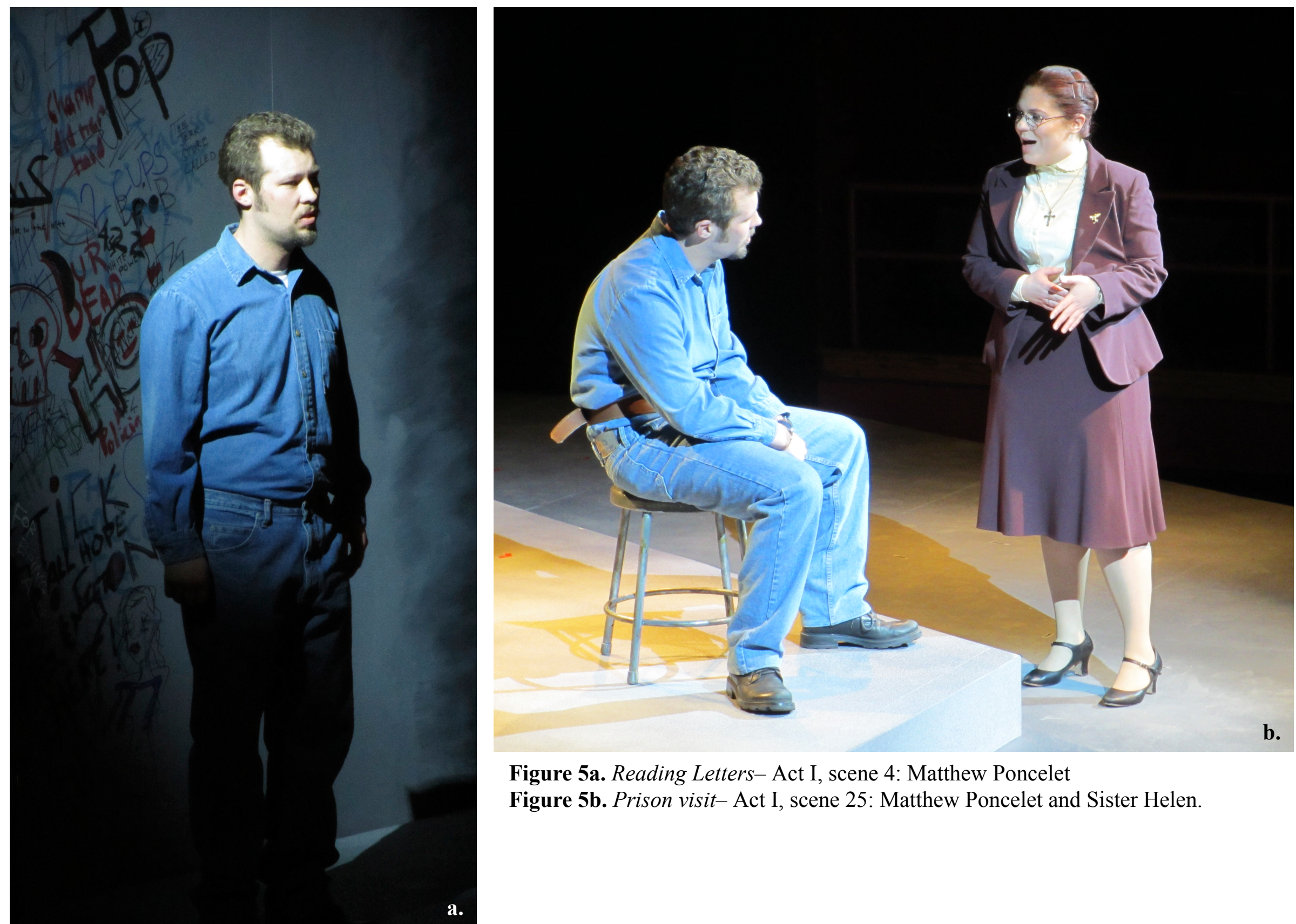

Figure 5a. Reading Letters- Act I, scene 4: Matthew Poncelet

Figure 5b. Prison visit- Act I, scene 25: Matthew Poncelet and Sister Helen. 

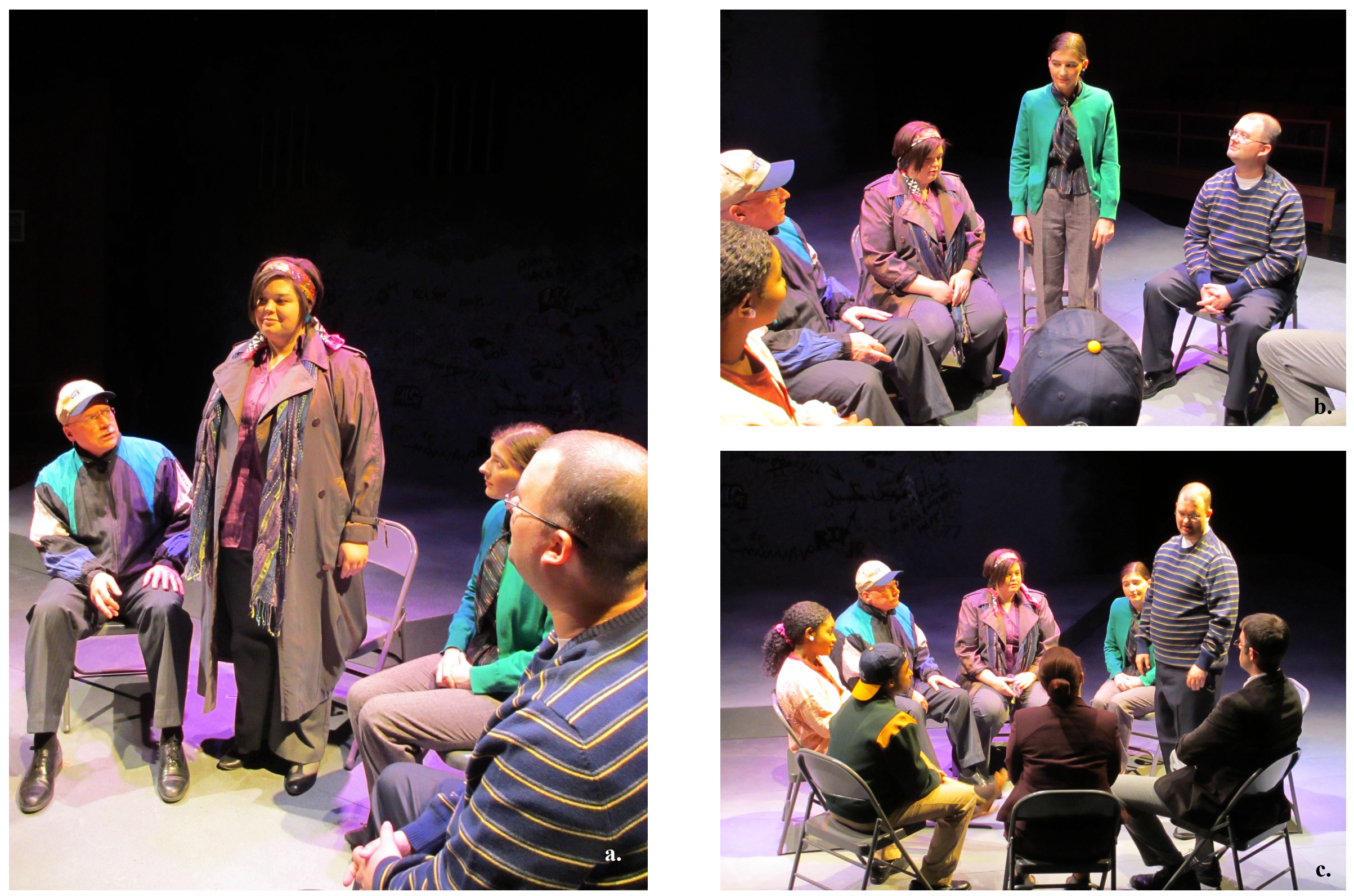

Figure 6a. Victim's Support Group- Act I, scene 31: (from left) Man 2, Woman 2, Woman 3, Man 3

Figure 6b. Victim's Support Group- Act I, scene 31: (from left) Woman 1, Man 2, Woman 2, Woman 3, Man 3

Figure 6c. Victim's Support Group- Act I, scene 31: all characters including Sister Helen and Mr. Delacroix 

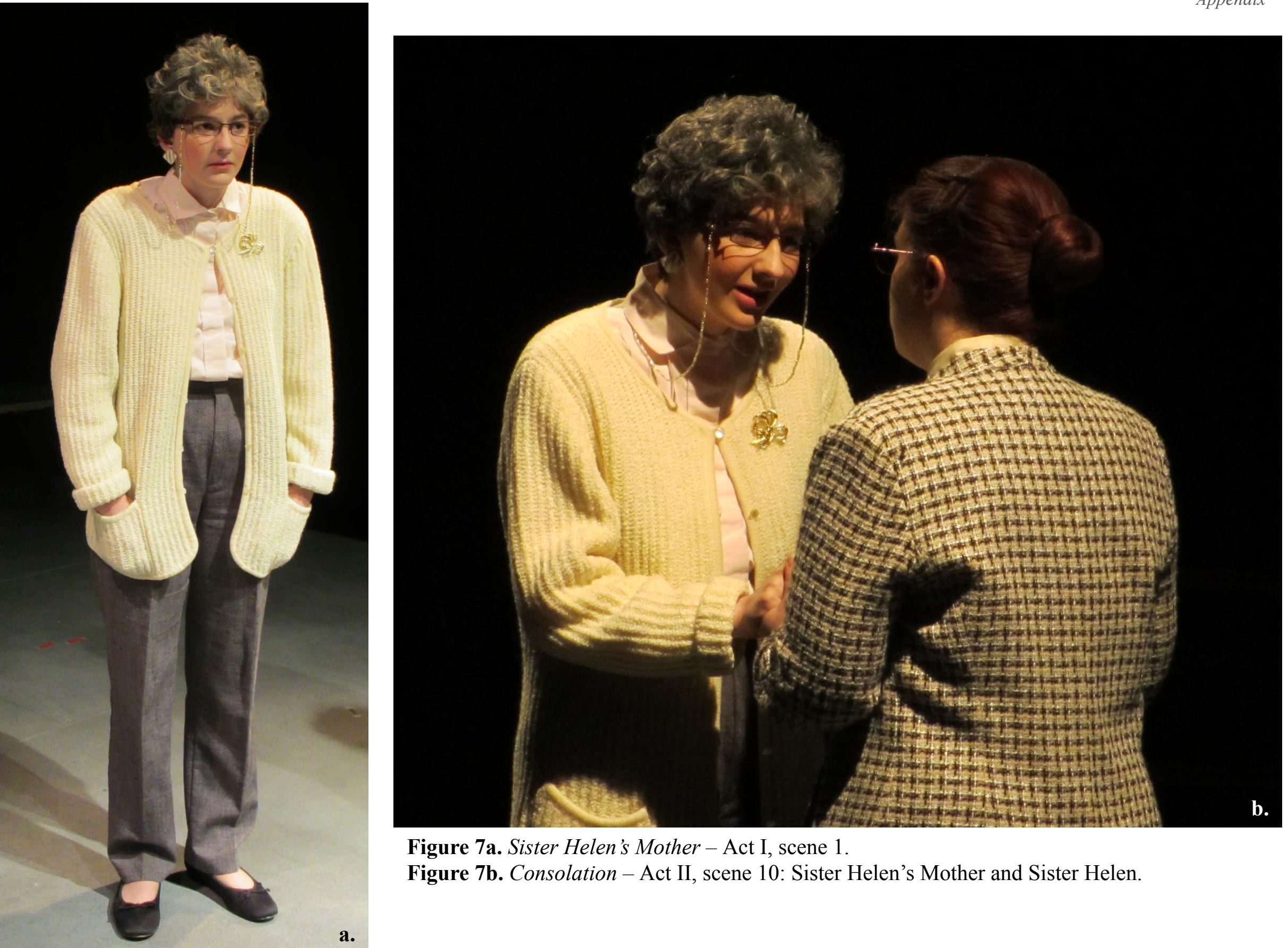

Figure 7a. Sister Helen's Mother - Act I, scene 1.

Figure 7b. Consolation - Act II, scene 10: Sister Helen's Mother and Sister Helen. 

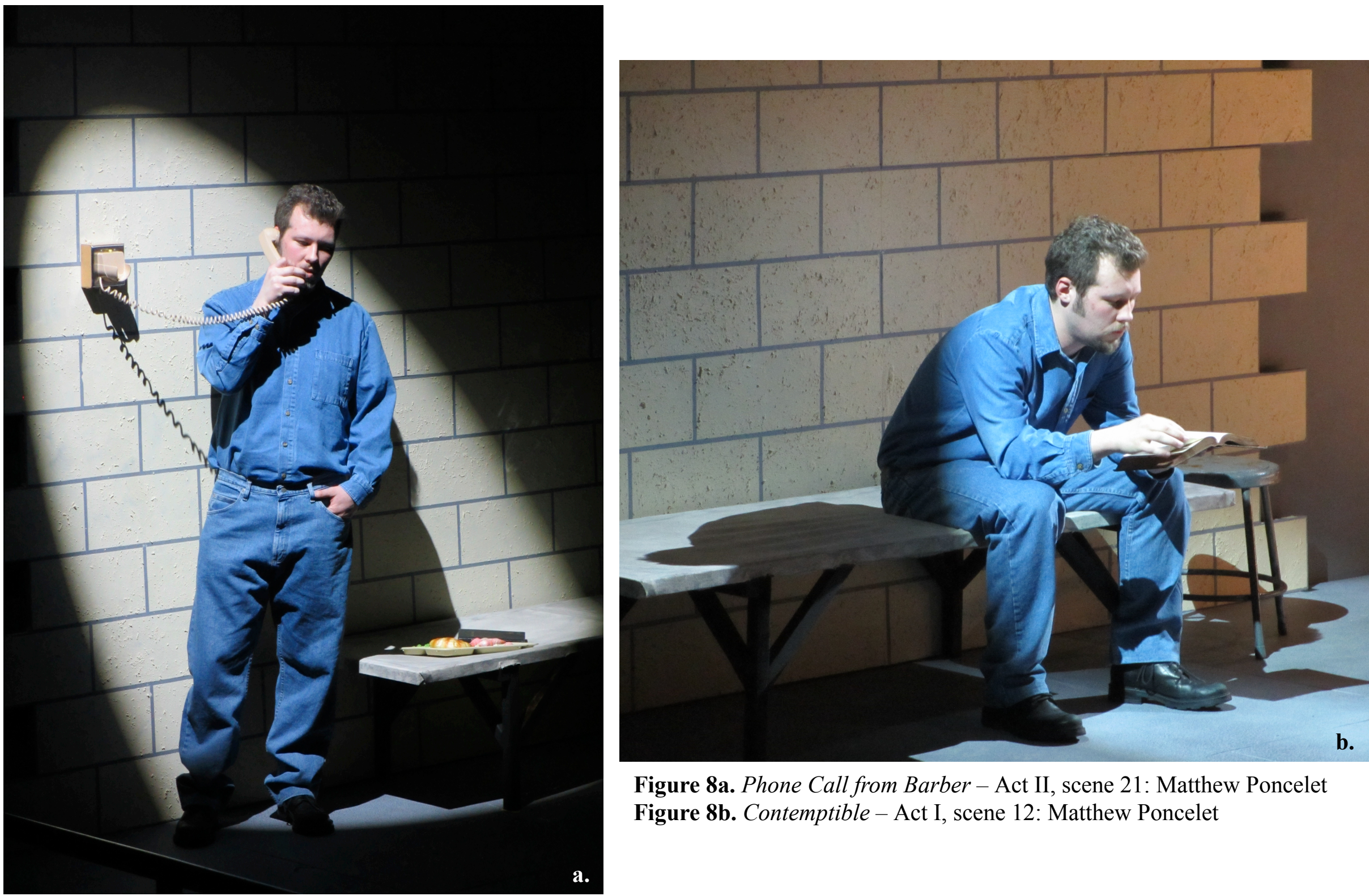

Figure 8a. Phone Call from Barber - Act II, scene 21: Matthew Poncelet Figure 8b. Contemptible - Act I, scene 12: Matthew Poncelet 

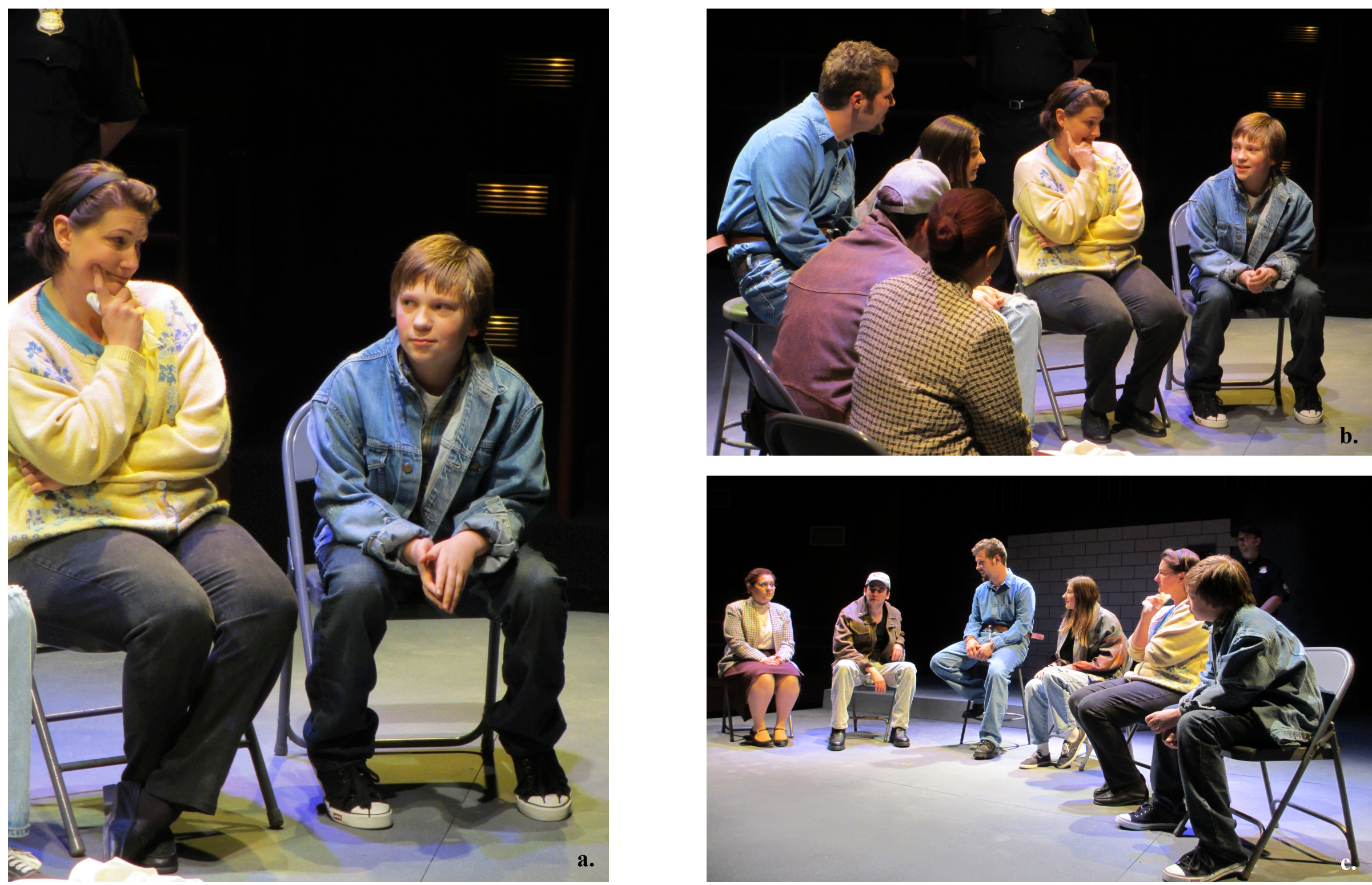

Figure 9a. Family Visit - Act II, scene 19: (from left) Lucille and Troy Poncelet

Figure 9b. Family Visit - Act II, scene 19: (clockwise) Sister Helen, Mitch, Matt, Jamie, Lucille, and Troy Poncelet

Figure 9c. Family Visit - Act II, scene 19: (from left) Sister Helen, Mitch, Matt, Jamie, Lucille, and Troy Poncelet 

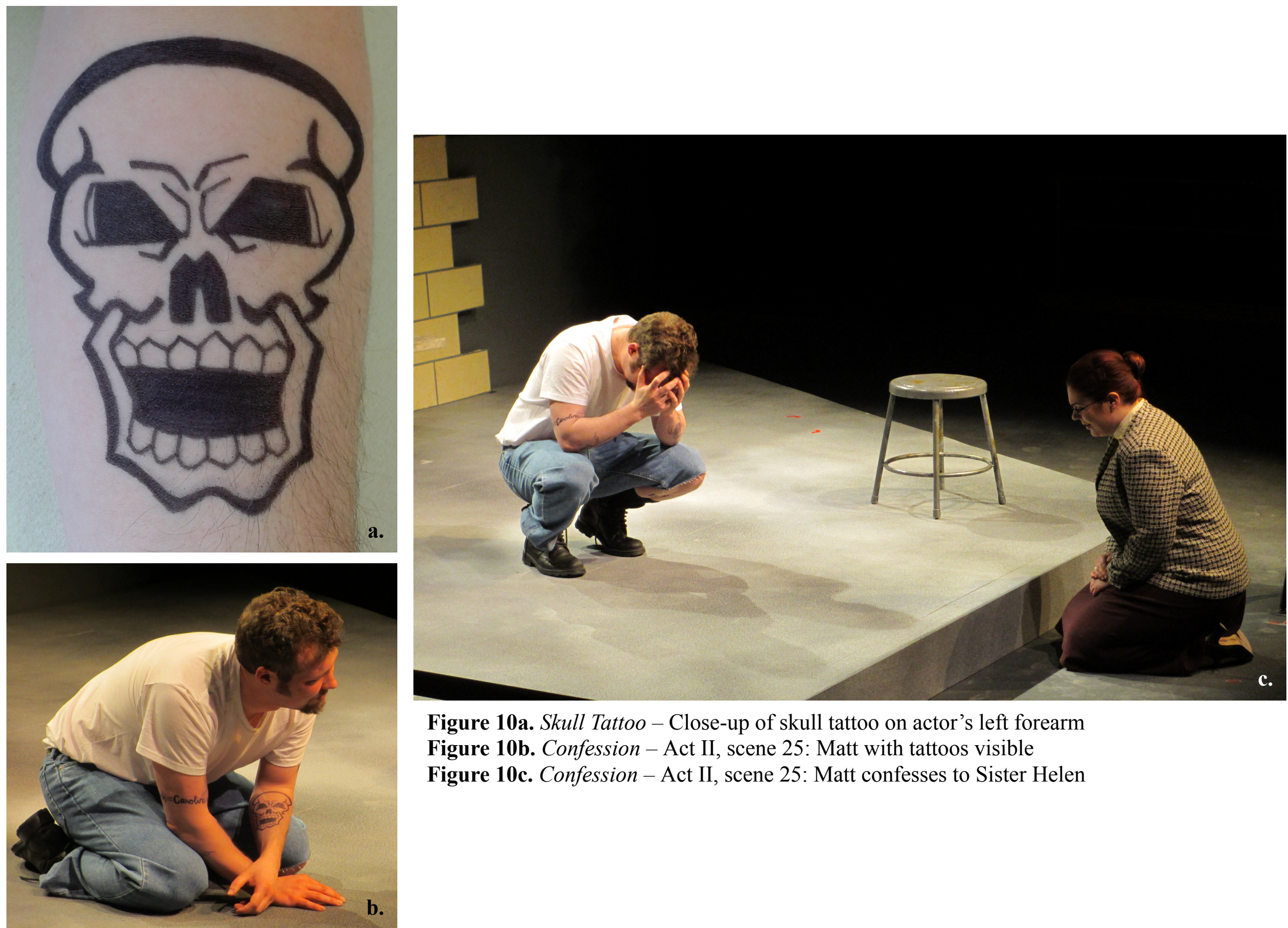

Figure 10a. Skull Tattoo - Close-up of skull tattoo on actor's left forearm

Figure 10b. Confession - Act II, scene 25: Matt with tattoos visible

Figure 10c. Confession - Act II, scene 25: Matt confesses to Sister Helen 


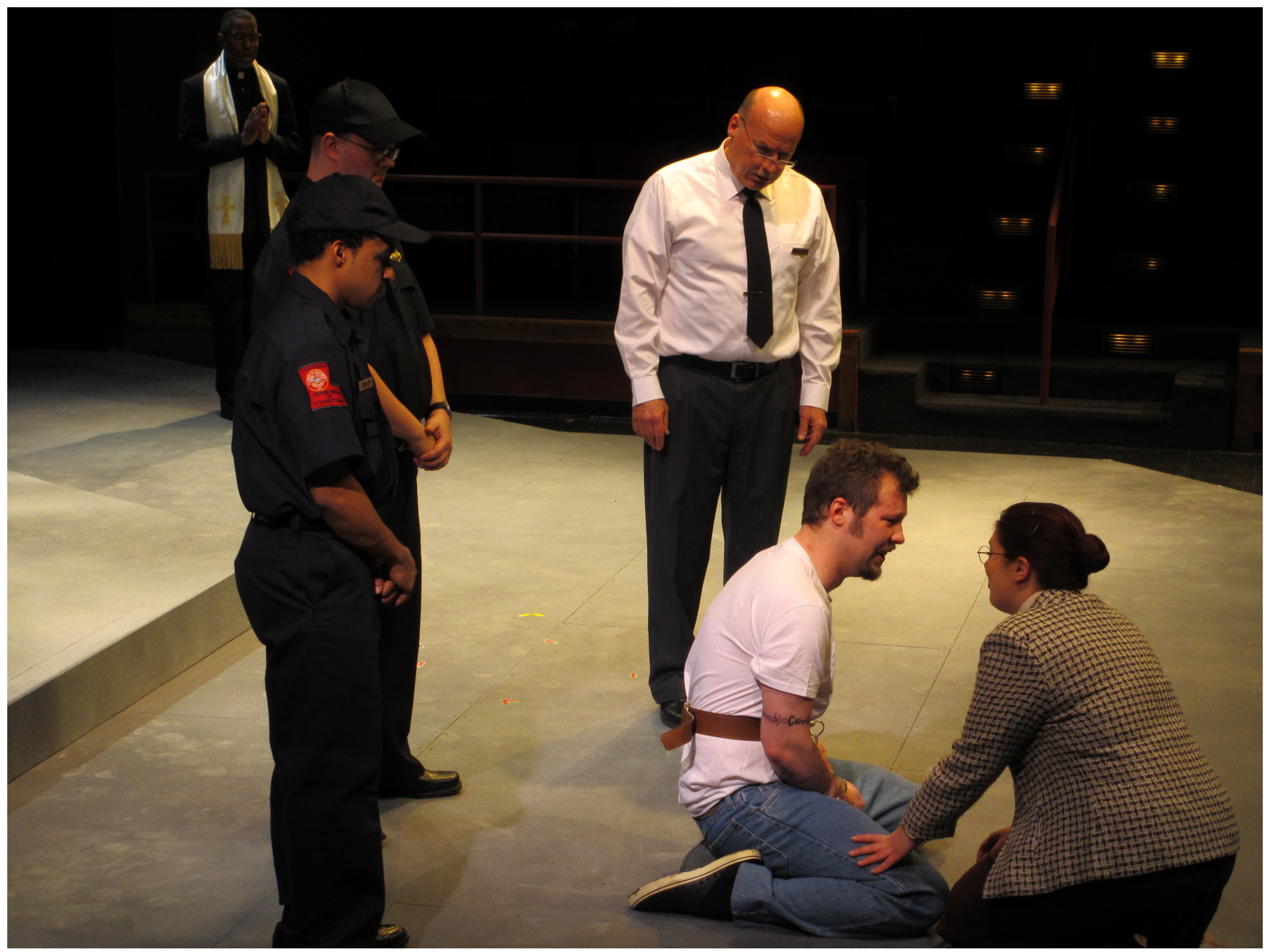

Figure 11. Walk to the Execution Chamber - Act II, scene 28: (from left) Guard Trapp, Sergeant Beliveau, Warden Hartman, Matt Poncelet, and Sister Helen; (in background) Father Farley 


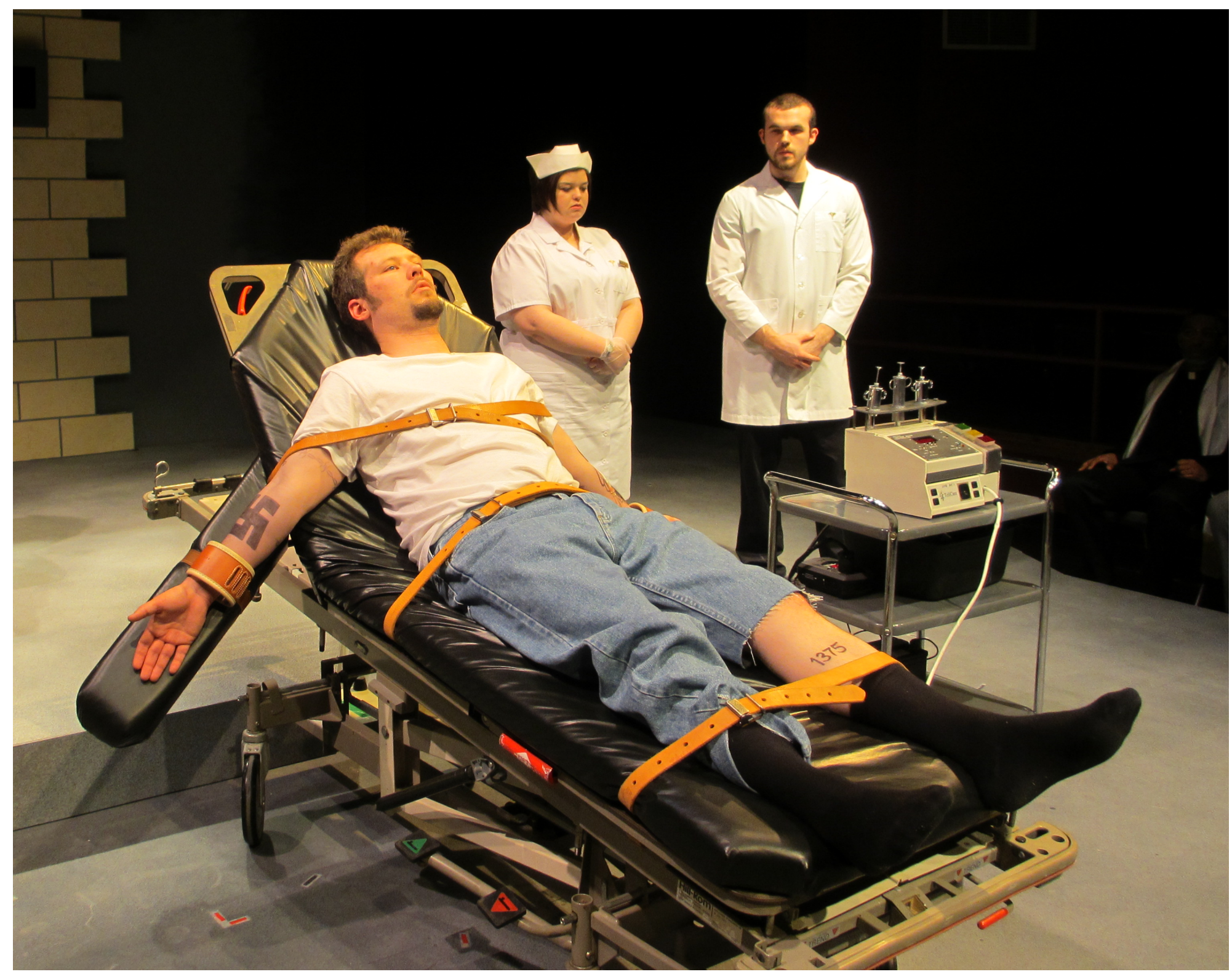

Figure 12. Execution - Act II, scene 29: (from left) Matt Poncelet, Nurse, and Doctor (stagehand in lab coat) 
Photos taken during the Media Shoot on January 17, 2014.
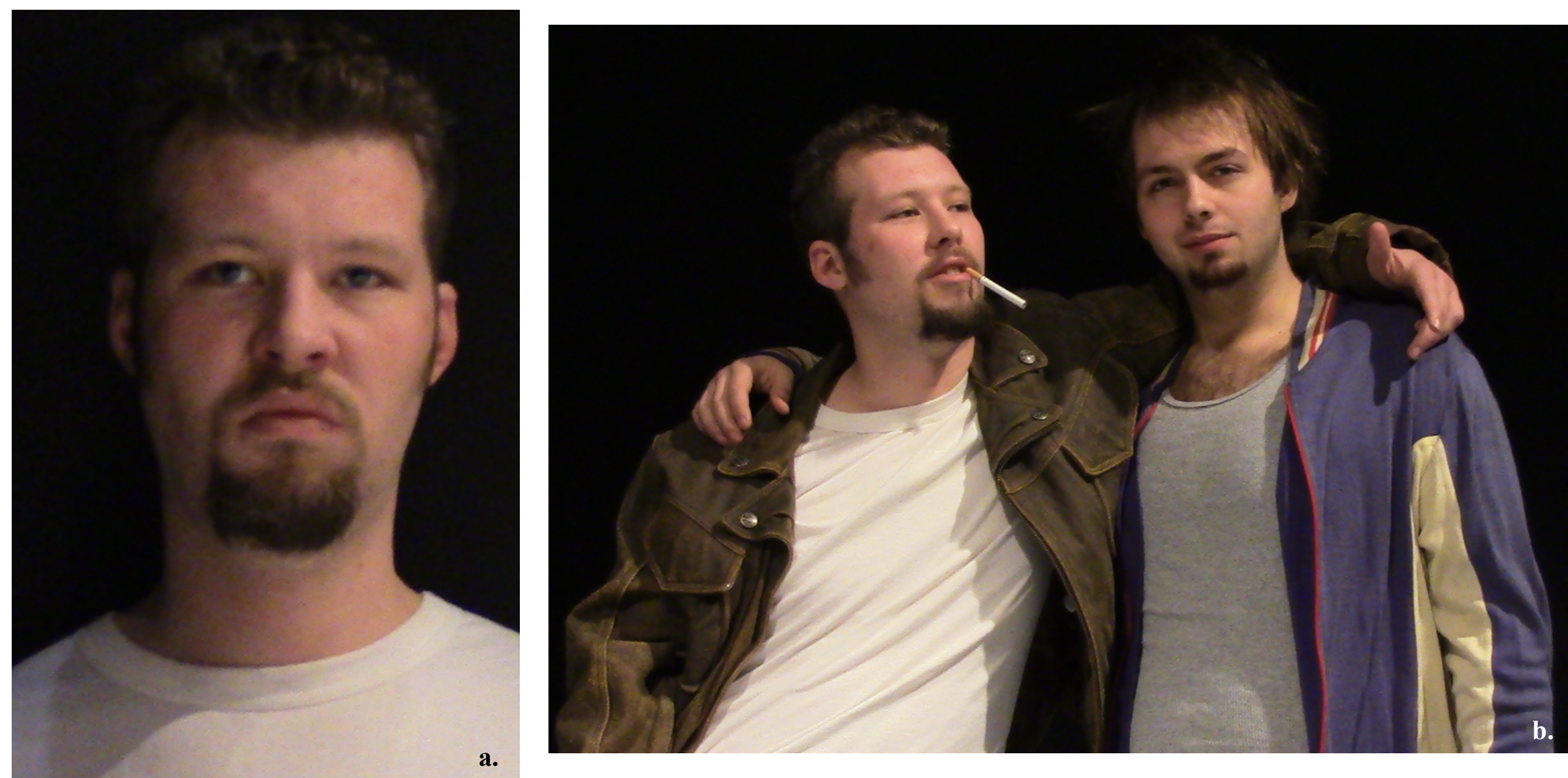

Figure 13a. Mug Shot - Matt Poncelet

Figure 13b. Buddies - Matt Poncelet (left) and Reese Fisher as Carl Vitello (right) 


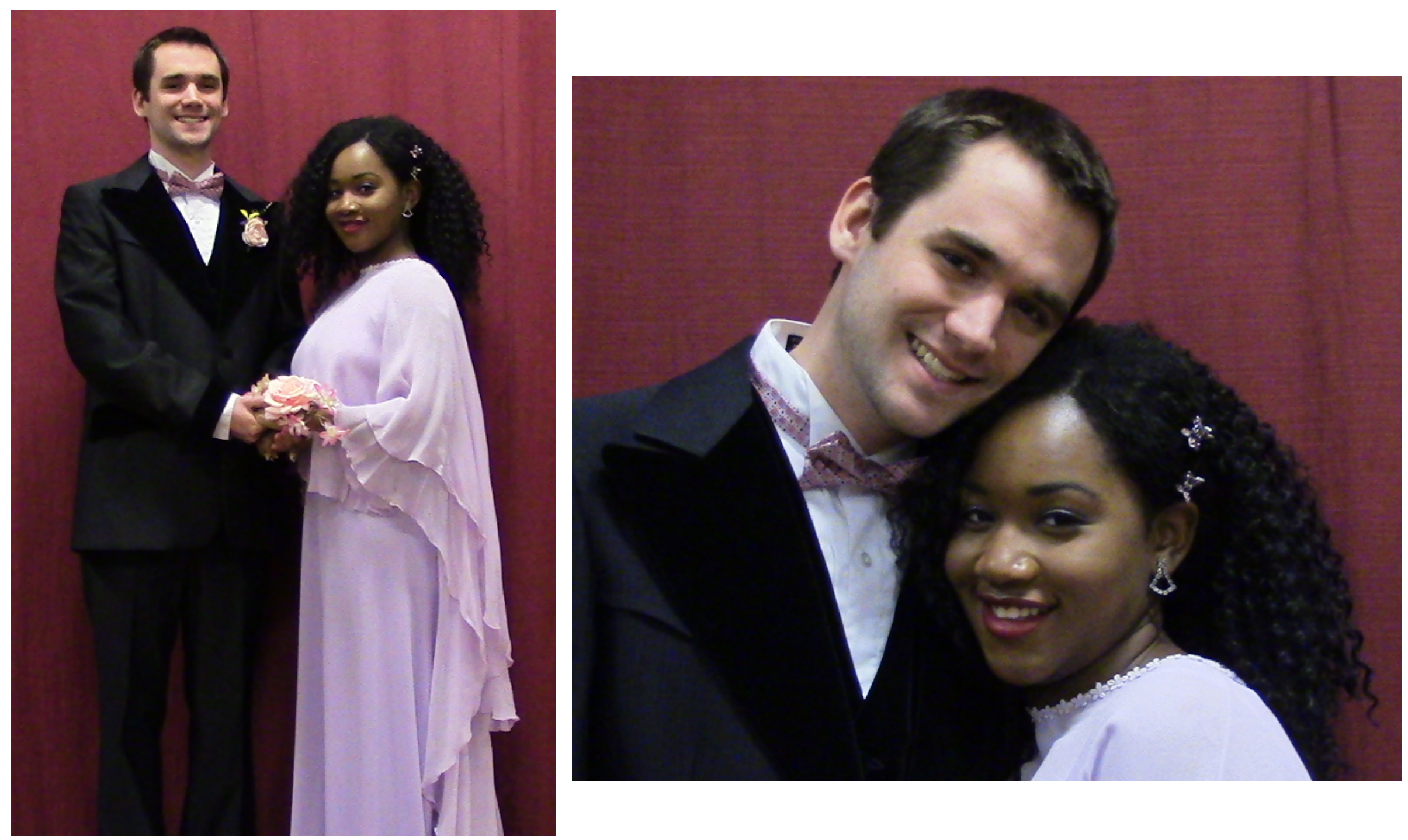

Figure 14. Prom Photos - Walter Delacroix and Hope Percy in late 1970s prom photo 

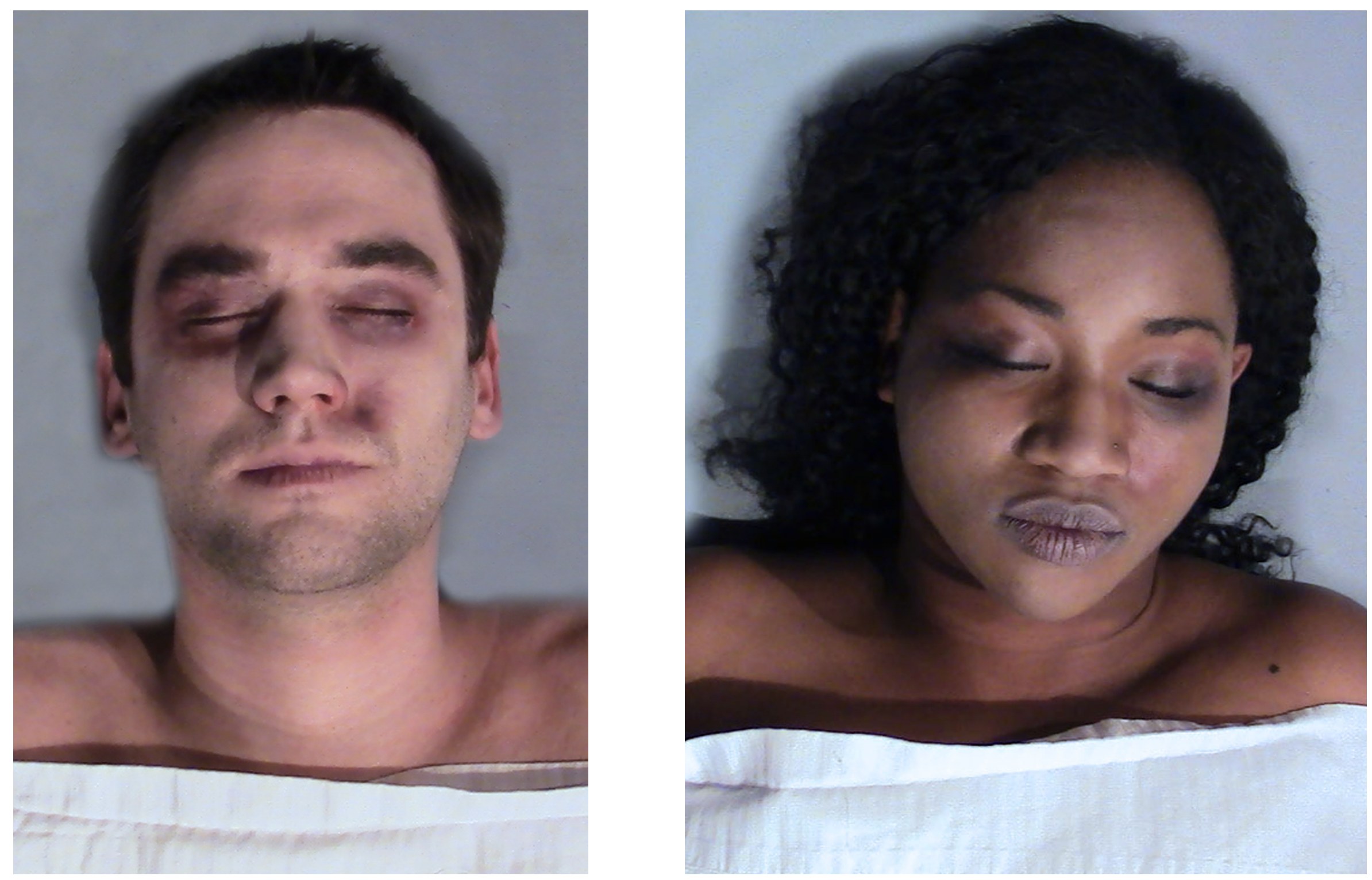

Figure 15. Morgue Photos - Walter Delacroix (left) and Hope Percy (right) in realistic corpse makeup 


\section{Costume Budget}

\begin{tabular}{|c|c|c|c|}
\hline Date & Vendor & Item & Price \\
\hline $12 / 4 / 13$ & Goodwill & Clothing & 55.00 \\
\hline $12 / 12 / 13$ & Target & Clothing and accessories & 31.18 \\
\hline $12 / 12 / 13$ & Walmart & Clothing & 150.74 \\
\hline $12 / 12 / 13$ & Goodwill & Belts & 3.00 \\
\hline $12 / 12 / 13$ & Bluegrass Uniforms & Guard uniforms & 303.92 \\
\hline $12 / 12 / 13$ & Goodwill & Jackets & 10.00 \\
\hline $12 / 17 / 13$ & PayPal (Ebay) & Guardian angel pin & 6.48 \\
\hline $12 / 18 / 13$ & PayPal (Etsy) & Boots & 101.56 \\
\hline $12 / 18 / 13$ & Amazon & Baseball shirt & 10.53 \\
\hline $12 / 18 / 13$ & Amazon & Baseball shirt & 17.38 \\
\hline $12 / 18 / 13$ & Amazon & Nurse uniforms & 61.96 \\
\hline $12 / 19 / 13$ & Walmart & Accessories & 59.74 \\
\hline $1 / 9 / 14$ & Target & Clothing & 73.97 \\
\hline $1 / 10 / 14$ & Caufields & Guard badges & 19.98 \\
\hline $1 / 10 / 14$ & Hobby Lobby & Jewelry supplies & 22.20 \\
\hline $1 / 10 / 14$ & Walmart & Clothing & 93.85 \\
\hline $1 / 10 / 14$ & Kohl's & Pants & 136.50 \\
\hline $1 / 11 / 14$ & PayPal (Ebay) & Louisiana patches & 22.00 \\
\hline $1 / 11 / 14$ & PayPal (Ebay) & Metal nametags & 69.00 \\
\hline $1 / 11 / 14$ & JCPenney & Pants, shirt & 72.07 \\
\hline $1 / 11 / 14$ & PayPal (Ebay) & Refund & -4.60 \\
\hline $1 / 13 / 14$ & PayPal (Etsy) & 1970s tux & 71.95 \\
\hline $1 / 13 / 14$ & PayPal (Etsy) & Stirrup leggings & 44.00 \\
\hline $1 / 13 / 14$ & Target & Clothing & 73.97 \\
\hline $1 / 13 / 14$ & Walmart & Accessories & 59.74 \\
\hline $1 / 13 / 14$ & Burlington Coat Factory & Sports coats and pants & 124.96 \\
\hline $1 / 21 / 14$ & PayPal refund & Badges & -53.82 \\
\hline $1 / 22 / 14$ & JoAnn Fabrics & Elastic & 4.08 \\
\hline $1 / 22 / 14$ & Caufield & Temporary colored hairspray & 15.96 \\
\hline $1 / 22 / 14$ & Walgreens & Cast covers & 15.49 \\
\hline $1 / 22 / 14$ & Walmart & Tights & 11.74 \\
\hline $1 / 27 / 14$ & Target & Clothing and supplies & 65.55 \\
\hline $1 / 27 / 14$ & Payless Shoe Store & Shoes & 59.98 \\
\hline $1 / 27 / 14$ & Walmart & Clothing and accessories & 88.25 \\
\hline $1 / 27 / 14$ & Goodwill & Clothing & 23.27 \\
\hline $2 / 19 / 14$ & Walmart refund & Jeans & -16.83 \\
\hline TOTAL & & & 1904.75 \\
\hline
\end{tabular}




\title{
COSTUME INVENTORY
}

The following is a list of all costume and accessory pieces included in the show.

\section{WOMEN}

\author{
Hannah Greene \\ 1 maroon tank top \\ 1 rainbow and black striped blouse \\ 1 green cardigan \\ 1 cream knit cardigan with 1 gold brooch \\ 1 painted leather jacket \\ 1 dark grey blazer \\ 1 pair light wash denim jeans \\ 1 pair grey dress pants \\ 1 grey short wig \\ 1 bag of bobby pins and rubber bands \\ 1 pair square frame glasses with pearl chain \\ 1 pair bright blue clip on earrings \\ 1 pair square white enamel clip on earrings \\ 3 gold disposable wedding bands \\ 2 pair opaque knee-highs \\ 2 pair white socks \\ 1 pair black satin flats \\ 1 pair navy blue Keds
}

\section{Tamara Kamara}

1 maroon T-shirt

1 pink T-shirt with rolled sleeves

1 navy guard uniform shirt

1 sea-foam green decorated sweatshirt

1 pastel pink knit cardigan

1 navy blazer

1 pair royal blue leggings

1 pair gold lame leggings with stirrups

1 blue, orange, teal and black circle skirt with attached white half-slip and pink leather belt

1 navy guard uniform pants (Belt sewn in)

1 fuchsia scrunchie hair tie

1 pair light purple sparkly earrings

1 pair dark blue sparkly earrings

1 pair hot pink sparkly earrings

1 black ball cap

1 orange, green, and white head wrap

1 white camisole

1 black and brown reversible belt (Sewn on pants)

1 red leather purse 
1 pair white socks with lace

2 pair black socks

1 pair blue and green tennis shoes

1 pair gold flats with bow

1 pair pink house slippers

1 pair black dress shoes (for guard uniform)

\section{Renea Brown}

1 cream blouse with Peter Pan collar

1 mint green cardigan with gold angel pin

1 rust bathrobe

1 brown pleated wool skirt

2 pair gold glasses frames

1 brown body slimmer

1 white camisole

1 silver and olive green cross on gold chain

3 silver disposable wedding bands

2 pair brown tights

1 white half-slip

\section{Megg Ward}

1 cream blouse with flower embroidery on collar

1 white, cream, and black tweed jacket with angel pin

1 maroon blazer with gold angel pin (suit)

1 maroon skirt (suit)

2 pair glasses frames

1 white camisole

1 gold cross on chain

3 silver disposable wedding bands

1 gold watch

1 nude foundation shorts

2 pair nude pantyhose

1 white half-slip

1 white full slip

1 prayer tag

\section{Magnolia Hensley}

1 purple short sleeve blouse

1 grey-blue blouse with navy stripes

1 khaki trench coat

1 brown/purple taffeta-like trench coat

1 purple, blue, green, and black floral print skirt

1 pair grey dress slacks

1 white nurse uniform with name badge (Koch, RN) and medical pin

1 white nurse's hat on head block

1 black plastic frame glasses

1 bag of white bobby pins

1 pair swirly mint green clip on earrings 
1 pair wooden circle clip on earrings

1 pair green and blue square clip on earrings

1 tan fully-body foundation garment

2 camisoles (white and off-white)

1 black and floral silk scarf

1 purple navy and green scarf

3 disposable gold wedding bands

1 small black watch

1 brown leather purse

3 pair white opaque tights

1 pair grey knee-highs

1 white half-slip

1 pair white Keds shoes

1 pair black T-strap character shoes

\section{Jennifer Cooper}

1 teal T-shirt

1 cream blouse

1 cream knit cardigan with blue flowers

1 tan cardigan with gold angel pin

1 red sweater jacket with gold and silver decoration

1 pair black jeans

1 maroon, grey, and black wool skirt

1 pair big red flower clip earrings

1 solid black headband

1 body slimmer (shorts style)

1 gold cross on gold chain

2 disposable silver wedding bands

2 pair brown tights

2 pair black knee-highs

1 pair black character shoes (Personal)

1 pair black leather loafers

\section{Tia Davis}

1 magenta button dress

1 grey cardigan with pink and blue flowers

1 purple, fuchsia, green and black color-block skirt

1 square silver pendent on silver chain

1 pair gold and purple circle earrings

1 pair silver pearl earrings

1 color block silk scarf (mostly purple)

3 disposable silver wedding bands

2 silver engagement rings

1 magenta belt

1 black leather pocket book

2 pair brown stockings

1 white full-length slip 


\section{MEN}

\section{Travis Stolp}

1 light grey dress shirt

1 shirt, navy and orange check on white

1 dark brown corduroy jacket

1 pair grey dress pants

1 pair wire frame glasses

2 white undershirts

1 grey striped tie with tan diamonds

1 navy necktie with light blue diamonds

1 gold wedding band

1 black and brown reversible belt

2 pairs black socks

1 pair black character shoes

\section{Rich VerWiebe}

1 orange and blue striped dress shirt

1 tan striped sweater vest

1 tan tweed sports coat

1 pair dark grey-brown pants

1 pair black glasses frames

2 white undershirts

1 brown tie with red paisleys

1 brown belt with gold buckle

2 pair brown socks

1 pair brown tassel loafers

\section{Phil Lynch}

1 white dress shirt

1 grey and white pinstripe suit coat

1 black, white, and green color block windbreaker

1 pair grey and white pinstripe suit pants

1 khaki and navy ball cap

2 pair of glasses (actor's personal items)

1 red with white diamonds zip tie

1 black clip on tie

1 pale blue zip on tie

1 blue pocket square (quick rigged)

1 American flag pin

1 nametag "HARTMAN"

1 gold tie bar

1 wedding band (actor's personal item)

1 gold and black watch

1 black and brown reversible belt

2 pair black socks

1 pair black lace up dress shoes

1 pair black patent leather dress shoes 


\section{Gary Brice}

1 black dress shirt with priest collar

1 black sports coat

1 cream priest stole with gold cross and gold tassels

1 pair black slacks

1 container of "snow white" hair dye

1 applicator for hair dye

2 white undershirts

1 pair gold and black glasses frames

1 black belt

2 pair black socks

1 pair black dress shoes

\section{Matt Klemenz}

1 navy blue guard uniform shirt

1 blue and white baseball tee with 3/4 raglan sleeves

1 distressed brown leather jacket

1 navy blue sports coat with silver buttons

1 pair acid-wash jeans

1 pair navy blue guard uniform pants

1 pair dark wash jeans

1 black ball cap

1 distressed tan ball cap with eagle design

1 black singlet

2 white undershirts

2 black and brown reversible belts (one is pre-strung through guard pants)

2 pair black socks

1 pair black zip-up boots

1 pair black character shoes

1 pair black high top Chucks

\section{David Galloway}

1 pair denim chambray shirt

1 pair denim jeans

1 pair denim jeans with cut off left leg

2 white undershirts

2 pair black socks

1 pair black "Crocs" slippers

1 pair black boots

1 black sharpie

\section{Eric Knoppkie}

1 denim chambray shirt with rolled sleeves

1 navy blue guard uniform shirt with sergeant insignia

1 navy blue and yellow striped pullover sweater

1 pair denim blue jeans

1 navy blue guard uniform pants

1 black ball cap 
2 white undershirts

1 black and silver watch

1 black and brown reversible belt

2 pair black socks

1 pair black boots

\section{Xavier Bleuel}

1 mint green and grey striped dress shirt

1 cream striped dress shirt

1 color block pullover sweater

1 white lab coat

1 grey wool sports coat

1 pair grey dress pants

1 pair black jeans

1 pair gold metal glasses frames

1 pair black plastic glasses frames

1 navy patterned tie

1 grey tie with teal diamonds

1 gold tie bar

2 white undershirts

1 gold wristwatch

1 black belt with gold buckle

2 pair black socks

2 pair white socks

1 pair black leather tie on shoes

1 pair yellow-orange high top chucks

\section{Crystian Wiltshire}

1 rust colored $\mathrm{T}$-shirt

1 western style shirt with tan, blue and black plaid

1 navy blue guard uniform shirt

1 forest green letterman jacket with orange leather accents

1 pair khaki pants

1 pair navy blue guard uniform pants

1 black ball cap

1 navy and gold ball cap

2 white undershirts

1 silver and black watch

1 black and brown reversible belt

1 black belt with silver buckle

1 brown "cowboy" style studded belt

2 pair tan socks

2 pair black socks

1 pair tan suede cowboy boots

1 pair black tie on dress shoes

\section{Byron Coolie}

1 denim chambray shirt 
1 cream and grey plaid dress shirt

1 grey dress shirt

1 pair denim jeans

1 pair brown dress pants

1 pair grey wool dress pants

2 white undershirts

1 maroon tie with white and blue dots

1 grey and black striped zip tie

3 disposable silver wedding bands

1 black and brown reversible belt

2 pair black socks

1 black pair boots

\section{Devin Ward}

1 blue plaid flannel shirt

1 denim jacket

1 pair dark wash jeans

2 white undershirts

2 pair white socks

1 pair black high-top Chucks

Michael Hushebeck (stagehand/doctor)

1 white labcoat 
Dead Man Walking

\section{CREDITS}

From the beginning, this project stressed cooperation and collaboration. It was not a singular effort that produced this show, nor was I alone responsible for creating the looks I put on stage. I owe my gratitude to the following people for helping my designs become reality:

Zhanna Goldentul, Thesis and Design Supervisor

Melissa Shepherd, Costume Shop Manager, Advisor

Costume shop crew:

James Coomer, Wardrobe Master

James Thompson, Costume Buyer

Amy Davis, Stitcher

Gina Vito, Stitcher

Anna Neikirk, Stitcher

\section{Costume running crew:}

Amy Davis 
Allen, Richard F. State of Alabama Department of Corrections: Dress Code. 1 Dec. 2010. PDF file.

Batchelor, Bob and Scott Stoddart. The 1980s. Westport, Connecticut: Greenwood Press, 2007. Print.

DeParle, Jason. "Victim's parents watch Willie die." The Times-Picayune [New Orleans, LA] 28 Dec. 1984. Print.

Louisiana State Penitentiary. Louisiana Department of Public Safety and Corrections. n.d. Web. 20 Sep. 2013.

Prejean, Helen. Dead Man Walking: An Eyewitness Account of the Death Penalty in the United States. New York: Vintage Books, 1993. Print.

Prejean, Helen. The Death of Innocents: An Eyewitness Account of Wrongful Executions. New York: Random House, 2005. Print

Robbins, Tim. Dead Man Walking. San Francisco: Tim Robbins, 2003. Print.

“How to make a Temporary Tattoo.” Indulgy. n.p., n.d. Web. 10 Jan 2014. 